\title{
Naming and describing the diversity in the Usnea cornuta aggregate (lichenized Ascomycota, Parmeliaceae) focusing on Brazilian specimens
}

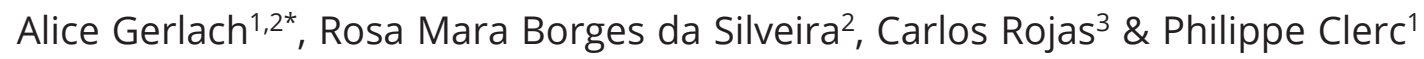

\section{Article info}

Received: 29 Jun. 2020

Revision received: 21 Aug. 2020

Accepted: 22 Aug. 2020

Published: 29 Dec. 2020

Associate Editor

Camille Truong

\begin{abstract}
This study is a reassessment of the Usnea cornuta aggregate diversity mainly in Brazil. Based on previous multi-locus species delimitation analyses using the multispecies coalescent model (MSC), we carried out a posteriori morphological and anatomical studies. The following corticolous new species are described: Usnea arianae with norstictic or fatty or lobaric acids, convex and efflorescent soralia and a lax medulla; U. flabelliformis with protocetraric acid, fan-shaped main branches and a high medulla/cortex ratio; U. rubropallens with protocetraric acid and a faint orange cortical/subcortical pigment; U. stipitata with constictic acid, stipitate soralia and a high medulla/cortex ratio; and U. tenuicorticata with protocetraric acid, a thin cortex and a high medulla/cortex ratio. The newly described species were found to occur so far only in the Americas, except $U$. arianae which shows an amphi-atlantic distribution in Europe and on the American continent. Seven species already described belonging to the $U$. cornuta aggr. in Brazil are further treated here: Usnea boomiana with caperatic acid and large, concave soralia, new to South America; $U$. brasiliensis with protocetraric acid, minute and irregular soralia; $U$. cornuta with mainly salazinic acid and minute soralia fusing into consoralia; $U$. macaronesica (syn. nov.: $U$. subglabrata) with barbatic acid, large excavate soralia and a lax medulla; Usnea subpectinata, a so far european species resurrected from the $U$. cornuta synonymy, with stictic acid and numerous isidiofibrils, new to South America; and U. trachyclada with thamnolic acid and $\mathrm{K}+$ bright yellow stipitate soralia. Full descriptions with morphological, anatomical and chemical features, geographical distributions, and illustrations are provided for each species along with an identification key.
\end{abstract}

Key words: Central America, Europe, multispecies coalescent (MSC) model, secondary metabolites, South America, species delimitation analyses, systematics.

\section{Introduction}

Identifying macrolichen species accurately by the phenotype-based approach is sometimes a true challenge, especially when characters are subject to strong modifications due to environmental pressure or convergent evolution. In these cases, it is difficult to interpret the value and the variation of the morphological characters used for species delimitation. Subtle differences might then escape the eye of the keenest taxonomist. For instance, it is estimated that the phenotype-base

\footnotetext{
${ }^{1}$ Conservatoire et jardin botaniques de la Ville de Genève, $1 \mathrm{ch}$. de l'Impératrice, 1292 Chambésy/GE, Switzerland

${ }^{2}$ Universidade Federal do Rio Grande do Sul, Instituto de Biociências, Departamento de Botânica, Laboratório de Micologia, Av. Bento Gonçalves, 9500 Campus do Vale, CEP: 91501-970, Porto Alegre/RS, Brazil

${ }^{3}$ Instituto de Investigaciones en Ingeniería, Universidad de Costa Rica, San Pedro de Montes de Oca, 11501, Costa Rica

* Corresponding author e-mail: alice gerlach @yahoo.com.br
}

species recognition vastly underestimates the number of species and that many apparently widely distributed species contain several semi-cryptic or cryptic species (Lumbsch \& Leavitt 2011). The now widespread adoption of DNA sequence variation data has led to a revolution in lichen systematics. The use of molecular sequences in a coalescence framework merging population genetics and phylogenetic approaches allows one to obtain direct genetic evidence of lineages status and to establish robust hypotheses of species boundaries (Naciri \& Linder 2015; Jones 2016; Gerlach et al. 2019). A posteriori morphological and anatomical studies of these lineages can then reveal subtle morphological differences that were previously overlooked. For instance, semi-cryptic species with subtle morphological differences were frequently found in macrolichens (Moncada et al. 2014; Dal Forno et al. 2017; Lücking et al. 2017a, b). 
The genus Usnea (Parmeliaceae) is among the most common macrolichen genera in (sub) tropical regions where it is particularly abundant in humid mountainous regions with frequent cloud formation. It corresponds to the second richest genus in the Parmeliaceae with over 400 species distributed worldwide (Clerc 2016). Although the genus is easily recognized due to the presence of usnic acid in the cortex and a central elastic axis, species delimitation is often problematic due to the extensive plasticity of morphological characters in response to environmental variation.

The species investigated in this study belong to the $U$. cornuta aggregate. They share a shrubby-erect to subpendulous thallus (Clerc 2011), \pm inflated branches constricted at their point of attachment, minute soralia of various shapes \pm covered with isidiomorphs (Gerlach et al. 2019) and a CMA (\% Cortex, \% Medulla and \% Central axis) of the cornuta- or brasiliensis-types as defined by Truong et al. (2011) and Gerlach et al. (2019). They mostly grow on trees (bark and twigs), on bushes or on fences. Their medullar chemistry was shown to be highly diverse (Gerlach et al. 2019), with $\beta$-orcinol depsidones acids (e.g., galbinic, protocetraric, salazinic stictic acids), orcinol depsidones (e.g., lobaric acid) and $\beta$-orcinol depsides (e.g., thamnolic acid). Usnea cornuta s.l. as an aggregate occurs worldwide on every continent (Gerlach et al. 2019).

In the past, Usnea cornuta s.l. was treated in a very wide sense by several European and North American authors (Brodo et al. 2001; Clerc \& Herrera-Campos 1997; Halonen et al. 1998; Saag et al. 2011) including, for instance, the thamnolic and the protocetraric acid chemotypes. Herrera-Campos et al. (2001) were the first modern authors to correctly segregate the protocetraric acid chemotype (U. brasiliensis s.1.).

In the first species delimitation analysis published for $U$. cornuta s.1. in the neotropics, Gerlach et al. (2019) worked on three 'morphospecies': the U. cornuta morphospecies with minute, numerous and confluent soralia which are even with the cortex, a cornuta-type CMA and a variable chemistry (salazinic, stictic, constictic, or thamnolic), the $U$. brasiliensis morphospecies with mostly stipitate soralia, a brasiliensis-type CMA, protocetraric or psoromic, and the U. dasaea Stirt. morphospecies with densely spinulous fibrils, a cornuta-type CMA and galbinic acid. In their study based on the multispecies coalescent (MSC) model, using ITS rDNA and two protein-coding genes, $M C M 7$ and $R P B 1$, Gerlach et al. (2019) found within the three former morphospecies at least nine strongly supported distinct taxa. These lineages were furthermore chemically well characterized. None of the 'morphospecies' were monophyletic, with the U. cornuta morphospecies corresponding to lineages 1, 3, 5, 9, 11 and 13 , the $U$. brasiliensis morphospecies corresponding to lineages 2, 4, 7 and the $U$. dasaea morphospecies corresponding to lineages 8 and 10 (Gerlach et al. 2019, Fig. 1).

In the present study we added more DNA sequences to the ones already published (Gerlach et al. 2019, Fig. 1) and used an integrative taxonomic approach based on a posteriori morphological and anatomical analyses to describe taxa belonging to the $U$. cornuta morphospecies (here $U$. cornuta aggr.) and to the $U$. brasiliensis morphospecies (here U. brasiliensis s.1.), focusing on Brazilian specimens with the addition of some Central American, Macaronesian and European specimens. The lineages with galbinic acid ( $U$. dasaea morphospecies) (lineages 8 and 10 in Gerlach et al. 2019) need more work and their taxonomy will be treated in a forthcoming paper.

We propose here the formal recognition of five previously undescribed species-level lineages in the Usnea cornuta aggregate, in addition to the resurrection of one additional species that has been earlier synonymized with $U$. cornuta s.str. We provide descriptions, illustrations and an identification key for all of the species studied here.

\section{Materials and methods}

\section{Taxon sampling}

This study considered specimens mostly collected in the Southern and Southeastern parts of Brazil, as indicated in Gerlach et al. (2019). Further field trips were performed by the first and last authors during December 2017 in four States: Rio Grande do Sul (Parque Nacional da Lagoa do Peixe), Santa Catarina (Parque Nacional de São Joaquim), Minas Gerais (Itamonte, Parque Nacional Itatiaia), and São Paulo (Campos do Jordão).

Several specimens were analyzed in this study. These were mainly collected in Brazil but records from Costa Rica, France, Portugal, Spain and Switzerland were also included. The localities and chemistry of all specimens analyzed are given in the Supplementary file S1. The collected specimens were deposited in G (specimens collected in the Canary Islands, Costa Rica, France and Switzerland) and in ICN with duplicates in G (specimens collected in Brazil). Herbarium specimens deposited in the following herbaria were also studied: G, HAS, ICN, JPB, LBL, MACB, and W.

\section{Morphology}

The morphology of specimens was examined using a Leica MS5 stereomicroscope. Morphological characters used in this study follow Clerc $(1998,2006)$, Clerc \& Herrera-Campos (1997), Herrera-Campos et al. (1998), Ohmura (2001), and Truong et al. (2011, 2013b).

\section{Soralia}

Soralia are one of the most important diagnostic characters in asexually reproducing species of the genus Usnea (Clerc 1987a, b, 1998, 2011; Clerc \& Herrera-Campos 1997; Herrera-Campos et al. 1998; Ohmura 2001). A posteriori morphological study of soralia in the Usnea cornuta aggr. based on the genetic lineages described in Gerlach et al. (2019) have led us to propose a description framework for these structures in the genus Usnea. This framework allows a detailed description of the subtle differences in several characters displayed by soralia. For each species when describing soralia, the following characters will be considered always in the same order from a) to $h$ ): 
a) Size: minute, punctiform ( $<1 / 2$ diameter of branch); large ( $\geq 1 / 2$ diameter of the branch); average size in $\mu \mathrm{m}$.

b) Shape - top view: irregular; circular; transversely elliptical; longitudinally elliptical.

c) Shape - side view: even with cortex; excavate; stipitate.

d) Surface: plane; convex (capitate); efflorescent (with soredia and isidiomorphs bursting off); concave.

e) Cortical rim: indistinct (edge of soralia with cortex not turned upward); thin, not conspicuous (edge of soralia with cortex slightly curved upward); thick and conspicuous (edge of soralia with cortex distinctly curved upward and thickened).

f) Density: sparse; dense; fully covering the branches (apices) and/or the fibrils; average number in $0.25 \mathrm{~mm}^{2}$.

g) Individuality: well distinct and separated; aggregating however without losing their individuality; fusing together, losing their individuality and forming consoralia.
A consoralia is thus defined here as an aggregate of small soralia having lost their individuality and looking like a large soralia.

h) Localization: on main branches and on terminal branches; mostly on terminal branches; on fibrils; at the edge of segments; in annular or longitudinal cracks of the cortex.

\section{Anatomy}

A measurement of the thickness of the cortex $(\% \mathrm{C})$ is given in percentage relative to the total width of the branch. The same is done for the medulla $(\% \mathrm{M})$ and the central axis $(\% \mathrm{~A})[\mathrm{CMA}]$. The measurements were carried out on a longitudinal section of the thickest part of the thickest branch of the thallus using a Leica MS5 stereomicroscope at $40 \times$ magnification according to the method given in Clerc (1987b). We performed one measurement per specimen analyzed.
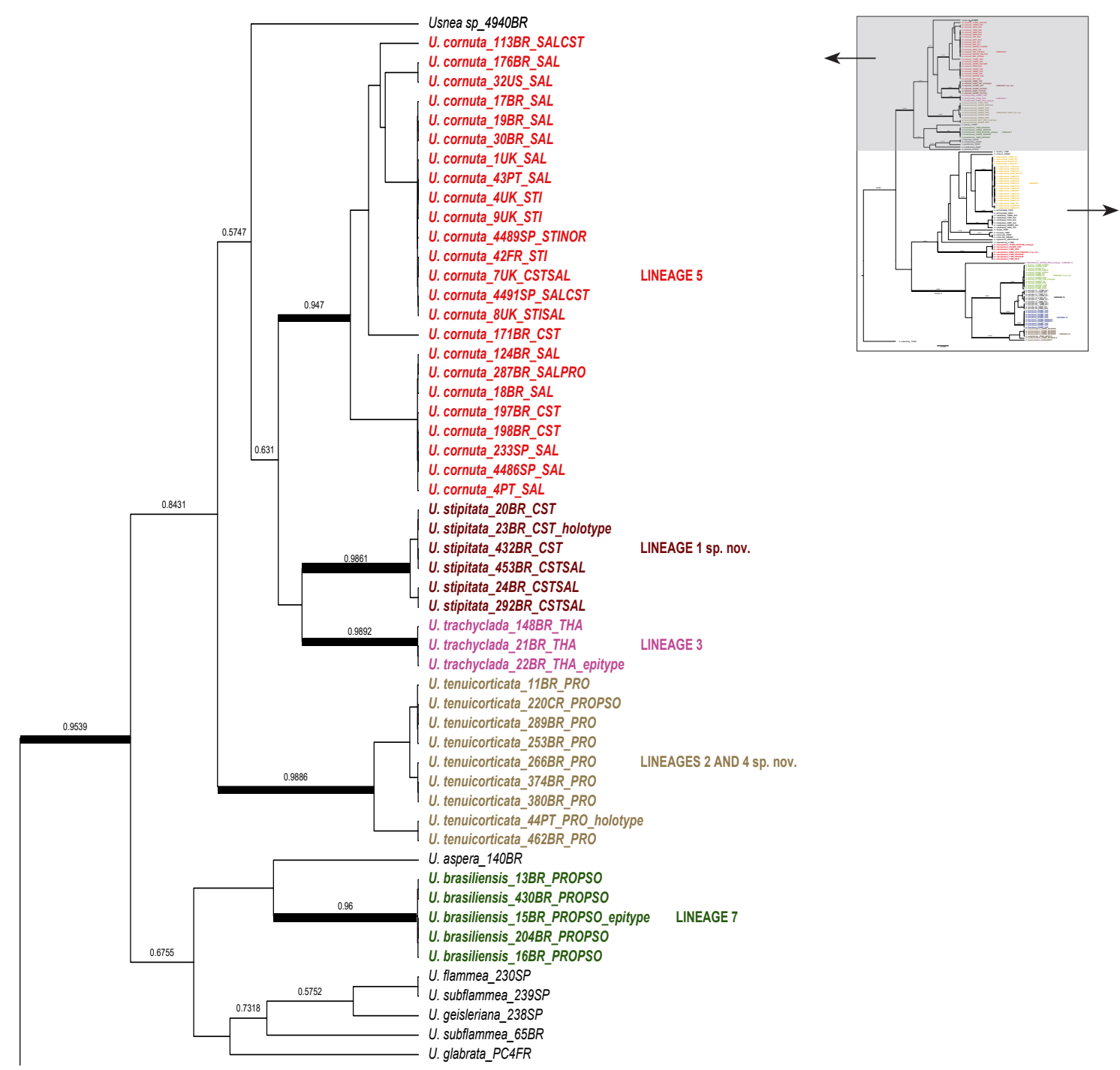

Figure 1. Species tree from STACEY analysis. Posterior probabilities $(\mathrm{PP}>0.5)$ are shown above branches. Branches and supported probabilities $(\mathrm{PP} \geq 0.90)$ are marked in bold. Species from the Usnea cornuta aggr. are highlighted in color. Lineages are indicated following Gerlach et al. (2019) except for lineages 15 and 16 newly mentioned in this study. Countries of origin are abbreviated as follow: Brazil (BR), Costa Rica (CR), Ecuador (EC), Peru (PE), France (FR), Portugal (PT), Spain (SP), United Kingdom (UK); United States (US), Switzerland (SW). The following major secondary products are indicated as follow: caperatic (CAP), constictic (CST); stictic (STI); salazinic (SAL); norstictic (NOR); galbinic (GAL); protocetraric (PRO), fumarprotocetraric (FUM); psoromic (PSO) acid; thamnolic (THA); lobaric (LOB). Modified from Gerlach et al. (2019). 


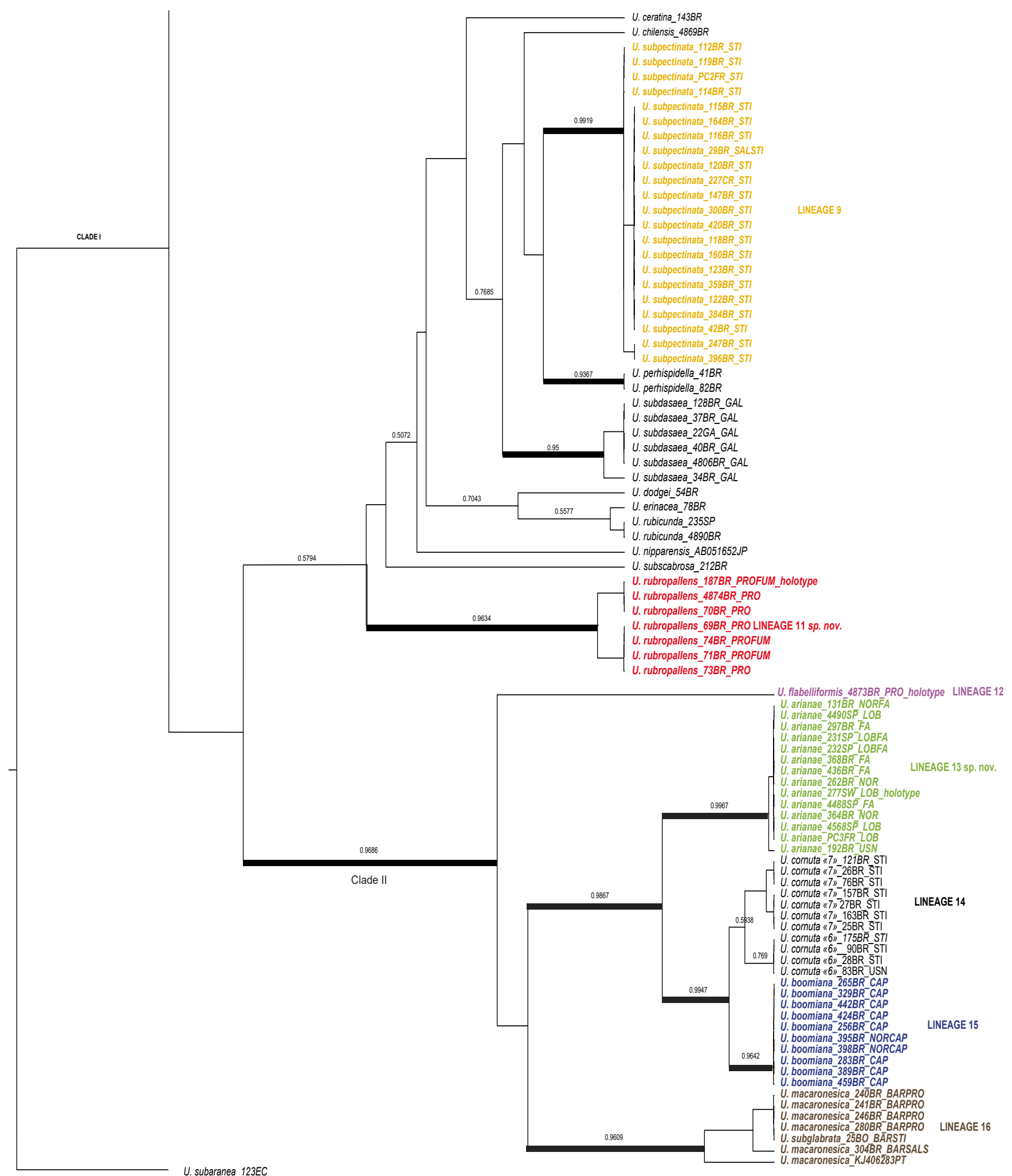

Figure 1. Continued.

The descriptions on the thickness of cortex, medulla and axis are given following the standardized classes proposed by Clerc (2011): cortex thin $(<6 \%$ of the radius), moderately thin $(6-8 \%)$, moderately thick $(8-10 \%)$ and thick $(>10 \%)$; medulla thin $(<18 \%)$, moderately thin (18-23\%), moderately thick (23-28\%), thick $(>28 \%)$; axis thin $(<30 \%)$, moderately thin $(30-40 \%)$, moderately thick (40-50\%), thick ( $>50 \%)$. The cortex plectenchyma-type was determined following Ohmura (2001) using a Leica DM2000 microscope.

\section{Chemistry}

Chemical analyses were performed on all cited specimens by thin-layer chromatography (TLC) following Culberson 
\& Ammann (1979) with solvent B modified according to Culberson \& Johnson (1982). K, C and P spot tests, according to Hale (1979), were directly applied to the medulla in longitudinal branch sections or onto the soralia. The species treated herein have a medulla reacting $\mathrm{K}+$, $\mathrm{P}+$ or $\mathrm{K}-, \mathrm{P}-$ (Usnea cornuta morphospecies) or $\mathrm{K}-, \mathrm{P}+$ (Usnea brasiliensis morphospecies). Since medulla and soralia might display different reactions to the spot tests, both should always be tested.

Molecular data, sequence alignment and species delimitation analysis

We generated sequences for 43 Usnea specimens following the methodology described in Gerlach et al. (2019). The present dataset has a total of 143 Usnea specimens mainly representing species of the $U$. cornuta aggregate (125 specimens, against 82 in Gerlach et al. 2019). From the 43 sequences added, one belongs to lineage 5, three to lineage 1 , six to lineage 2 , one to lineage 7 , six to lineage 9 , four to lineage 11 , six to lineage 13 , ten to lineage 15 and six to lineage 16 .

Sequences from GenBank of four species (Usnea macaronesica P. Clerc, U. nipparensis Asahina, U. subdasaea Truong \& P. Clerc and U. subglabrata Truong $\&$ P. Clerc) were added in order to support our species delimitations hypotheses. Usnea subaranae Truong $\&$ P. Clerc from Ecuador was chosen as out-group since it falls within the more basal group of Usnea according to Truong et al. (2013a) (Supplementary file S2).

To infer the number of potential species in the Usnea cornuta aggr., we performed a species tree analysis based on the multispecies coalescent model (MSC, Rannala \& Yang 2003) using the program STACEY version 1.2.2 (Jones 2016) implemented in BEAST 2.5.1 (Bouckaert et al. 2014). Molecular analyses were carried with the three markers, ITS, MCM7 and RPB1. The input files were prepared using the STACEY template supplied by BEAUTI2 (Bouckaert et al. 2014) with the same prior indications as in Gerlach et al. (2019). The input file was run for 200 million generations by sampling every 10,000 log and 100,000 tree in four parallel chains. Chain convergence and ESS values for the estimated parameters were checked using TRACER v1.6 (Rambaut et al. 2013). Tree files from two independent runs were combined with LogCombiner v2.5.1. Estimated species trees were summarized in Tree Annotator v2.5.1 with the maximum clade credibility (MCC) tree option after discarding the first $10 \%$ generations as burn-in. The tree was viewed in Figtree v1.4.3 (http://tree.bio.ed.ac.uk/software/figtree/). Clades with posterior probabilities $(\mathrm{PP})>0.90$ were considered as highly supported.

MCMC samples of the species trees from the STACEY runs were further processed via the Species Delimitation Analyzer tool (Jones et al., 2015; Jones, 2016) to calculate the probability that pairs of individuals belong to the same cluster using the options of $10 \%$ as burnin, $1.10-4$ collapse height and 1.0 similarity cut off. The output from the species delimitation analyzer was then uploaded to RStudio v1.2.5 (RStudio team 2015) using the script provided by Jones et al. (2015) to construct the similarity matrix.

\section{Results and discussion}

We described five new species that were all highly supported by our previous molecular studies: Usnea arianae, $U$. flabelliformis, U. rubropallens, U. stipitata, and U. tenuicorticata. All of these new species are described based on phenotypical, chemical and molecular features. Usnea boomiana and $U$. subpectinata are newly reported from South America. The detailed description of U. trachyclada is provided here for the first time since its description in 1891.

\section{Molecular data}

Overall, 40 ITS sequences, 35 MCM7, and 27 RPB1 sequences were newly generated for this study. Sequences from Costa Rica, France, Portugal, and Spain were generated by Gerlach et al. (2019). Our data set displays a small fraction of missing data. The ITS alignment has 483 nucleotide characters and 142 sequences $(0.7 \%$ missing data). The $M C M 7$ alignment has 439 nucleotide characters and 126 sequences (12\% missing data), whereas $R P B 1$ has 531 nucleotide characters and 119 sequences (16\% missing data).

\section{Species delimitation analysis}

There are many methods that implement the MSC model; however, they either require the a priori assignment of samples to species or they do not simultaneously estimate gene trees and the species tree (Gerlach et al. 2019). STACEY allows *Beast analyses without prior taxonomic assignment, searching the tree space while simultaneously collapsing very shallow clades in the species tree (controlled by the parameter collapseHeight); moreover, this package integrates out the population size parameter and has new MCMC proposal distributions to more efficiently sample the species tree, which decreases time until convergence (Andermann et al. 2019).

A modified species tree from Gerlach et al. (2019) is presented here (Fig. 1). Individual gene trees were generally in agreement with each other and with the species tree. An exception occurs with U. boomiana and U. cornuta that appears in two different clades in the ITS tree, but without support. Usnea boomiana, U. tenuicorticata, and $U$. subpectinata, also appear in different clades in the $M C M 7$ tree, but without support as well (Supplementary files S3, S4, S5, and S6).

The new generated species tree is consistent with the results reported in Gerlach et al. (2019) with two well supported main clades. Although the species studied herein are well supported in the species tree, the phylogenetic relationships among the species remain unresolved (Fig. 1). The chemistry of the specimens newly added to the tree fits well the chemistry of the lineages they are nested in. This confirms the correlation found in Gerlach et al. (2019) between the chemistry and the different 
lineages, showing the importance of this character in the U. cornuta aggregate.

The Usnea cornuta s.str. clade (Fig. 1) (lineage 5 in Gerlach et al. 2019) is now well supported $(\mathrm{PP}=0.95)$ contrasted with the low support in Gerlach et al. (2019). This is probably due the removal of one specimen from Peru poorly assigned to this lineage 5 (corn29PE, Fig. 2, in Gerlach et al. 2019). Lineage 2 (with protocetraric acid, Madeira) and lineage 4 (with protocetraric acid, Brazil) in Gerlach et al. (2019) cluster now together in a well supported lineage $(\mathrm{PP}=0.98)$. This lineage corresponds here to the newly described species U. tenuicorticata.

The pairwise matrix, summarizing all of the MCMC trees generated, giving posterior probabilities for pairs of individuals that belong to the same species (Fig. 2), shows that many individuals identified as belonging to the same species clustered together, usually with a high posterior probability. Usnea cornuta Körb. s.str. is now divided into two main subgroups (three in Gerlach et al. 2019, 5A-C; Fig. 2), of which only one specimen (corn171BR) remains poorly assigned to this lineage.

\section{Chemistry}

There is a strong correlation between chemotypes and genetic lineages (Gerlach et al. 2019, Table 1). This correlation is confirmed here after adding more sequences from specimens belonging to all lineages of the $U$. cornuta aggr. The majority of the species contained depsidones as main medullary chemistry: Usnea brasiliensis, U. flabelliformis, U. tenuicorticata and U. rubropallens have protocetraric acid; U. stipitata, constictic acid; $U$. cornuta has salazinic acid or stictic acid accompanied or not by other depsidones. Usnea boomiana has caperatic acid, a fatty acid. Usnea macaronesica has the depside barbatic acid and $U$. trachyclada the depside thamnolic acid. Usnea arianae has the most complex chemistry with the orcinol-depsidone lobaric acid sometimes accompanied or not by fatty acid, or fatty acid alone, or the depsidone norstictic acid accompanied by lobaric acid or accompanied with fatty acid.

The specimens from Brazil identified as $U$. arianae do not produce lobaric acid. They have norstictic acid with or without an unknown fatty acid instead. Usnea cornuta can have stictic acid as the main chemistry; however, this chemotype was not found in Brazil either, whereas the chemotype constictic acid was found only in Brazil. Usnea macaronesica was mentioned in the literature with barbatic and stictic acids. However, a chemotype barbatic with protocetraric acid was found for the first time, occurring so far only in Brazil. The chemotype with stictic acid can be also found in Brazil, although it is less frequent there.

The location of the secondary compounds is a second character that was shown to be of interest in Usnea. For instance, alectorialic acid was found exclusively in the apothecia of $U$. florida (Clerc 1984) and in the soralia of U. viktoriana (Clerc \& Otte 2018). Among the species studied here, thamnolic acid is present in large amounts only in the soralia of $U$. trachyclada. Therefore, the soralia of this species reacts $\mathrm{K}+$ bright yellow (thamnolic acid)

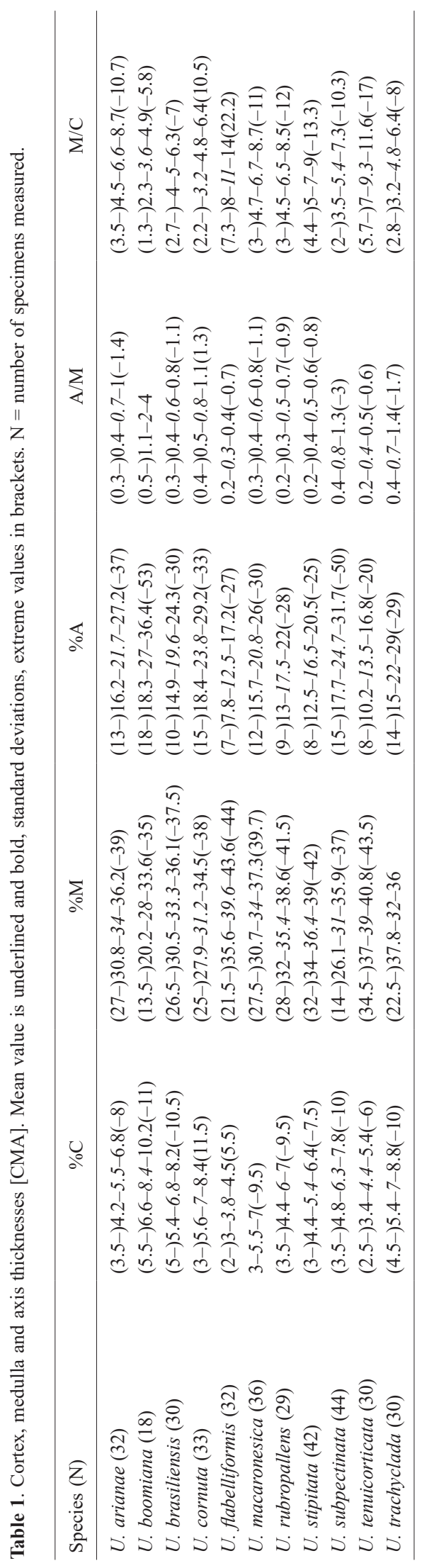

while the medulla is $\mathrm{K}$-. This is a diagnostic character to separate $U$. trachyclada from the other species of the $U$. cornuta morphospecies. In U. brasiliensis s.str., $U$. flabelliformis and U. tenuicorticata, psoromic acid is detected only in the soralia that are $\mathrm{K}+$ pale yellowish orange while the medulla is $\mathrm{K}-$. 

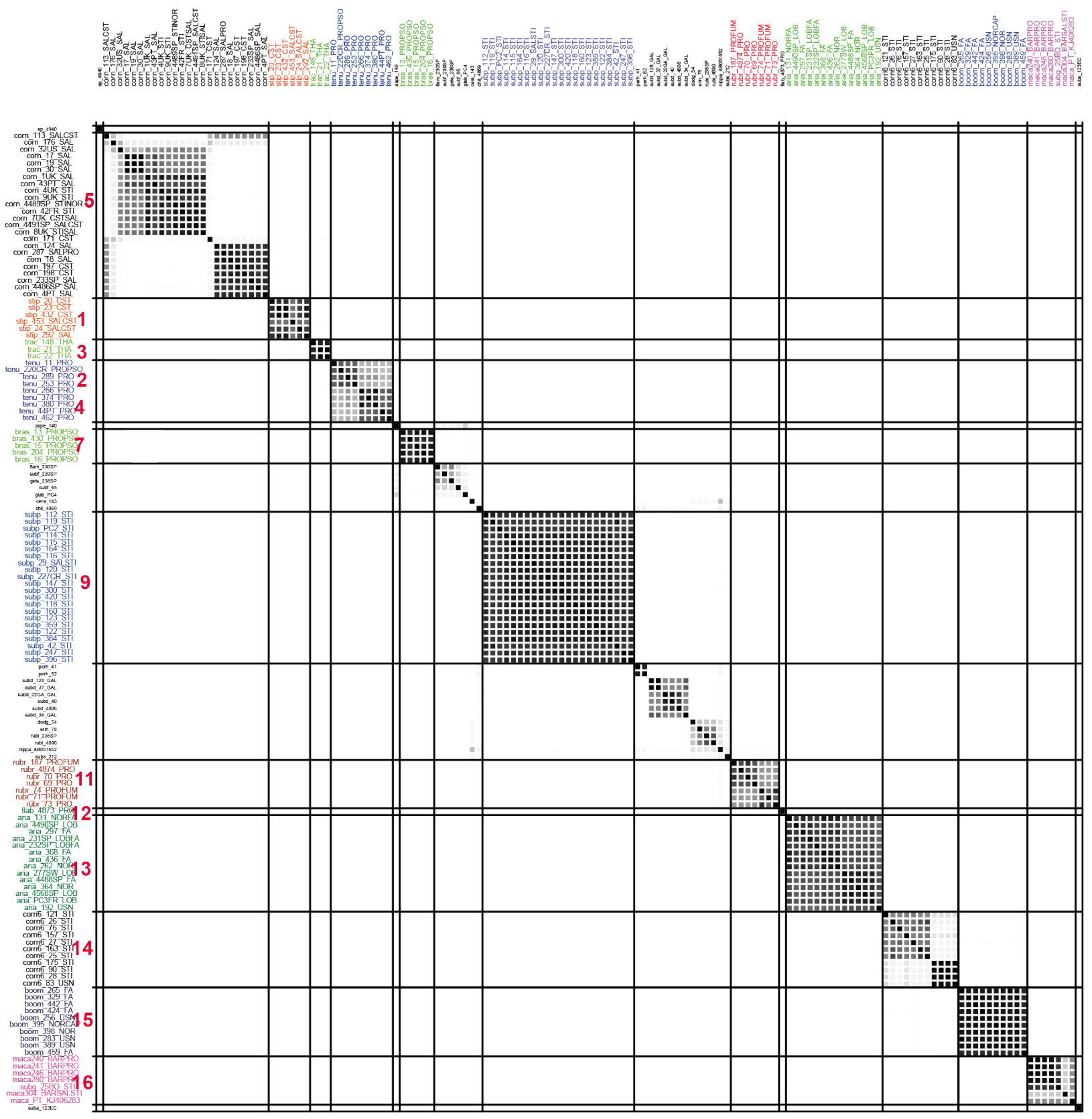

Figure 2. Similarity matrix from STACEY analysis. The squares represent posterior probabilities (white $=0$, black $=1$ ) for pairs of individual to belong to the same cluster. Their corresponding lineages are indicated in red. Species names are abbreviated with the first four letters: $U$. cornuta (lineage 5), U. stipitata (1), U. trachyclada (3), U. tenuicorticata (2 and 4), U. brasiliensis (7), U. subpectinata (9), U. rubropallens (11), U. Alabelliformis (12), U. arianae (13), undescribed and unsupported lineage 'corn6' (14), U. boomiana (15), U. macaronesica (16).

For each species, the number of specimens (n) analyzed by TLC is given in the description. Table 2 summarizes the chemical data for all of the species treated here and Figure 3 displays the main diagnostic substances for each species studied here.

\section{Taxonomy}

The morphology of soralia is an important diagnostic character in Usnea (Clerc 1984, 1997; Ohmura 2001). Although most of the species described below, do possess specific soralia characters when growing under optimal conditions, many of these species show a high variability in these characters. Especially the size, the presence of a cortical rim, the ability to aggregate or to fuse to form consoralia and the shape in side view ( \pm stipitate) can vary to a large extent. This might happen for instance when lichenicolous fungi are present, or under extreme climatic conditions (high humidity, extreme temperatures, strong winds, etc.). In this manner, specimens of the same species or even different branches of the same thallus can sometimes have different types of soralia. Considerable caution is advised when looking at the soralia in this genus and the descriptions given above are valid only for mature standard specimens growing in their optimal habitat.

The A/M ratio is an important diagnostic character (Truong et al. 2011, 2013b; Truong \& Clerc 2016; Gerlach et al. 2017). Gerlach et al. (2017) defined 
Table 2. Major secondary metabolites (columns) and chemotypes (lines) detected by TLC. Abbreviations for secondary metabolites: BAR = barbatic, $\mathrm{CAP}=$ caperatic, $\mathrm{NOR}=$ norstictic, $\mathrm{SAL}=$ salazinic, $\mathrm{STI}=$ stictic, $\mathrm{CST}=$ constictic, $\mathrm{PRO}=$ protocetraric, $\mathrm{FUM}=$ fumarprotocetraric, $\mathrm{PSO}$ $=$ psoromic, $\mathrm{LOB}=$ lobaric, $\mathrm{THA}=$ thamnolic, $\mathrm{FA}=$ unidentified fatty acid; $\mathrm{Ch}=$ chemotype $\mathrm{N}=$ number of specimens studied; $+=$ presence constant within species; $\pm=$ presence variable among specimens within species; $\mathrm{tr}=$ present in traces.

\begin{tabular}{|c|c|c|c|c|c|c|c|c|c|c|c|c|c|c|c|}
\hline Species & $\mathrm{Ch}$ & $\mathrm{N}$ & BAR & CAP & NOR & SAL & STI & CST & PRO & FUM & PSO & LOB & THA & FA & Medulla color test \\
\hline \multirow[t]{4}{*}{ U. arianae } & 1) & 10 & & & & & & & & & & + & & \pm & $\mathrm{K}-, \mathrm{P}-$ \\
\hline & 2) & 6 & & & & & & & & & & & & + & $\mathrm{K}-, \mathrm{P}-$ \\
\hline & 3) & 4 & & & + & & & & & & & + & & & $\mathrm{K}+$ reddish \\
\hline & 4) & 3 & & & + & & & & & & & & & + & $\mathrm{K}+$ reddish \\
\hline \multirow[t]{2}{*}{ U. boomiana } & 1) & 11 & & + & & & & & & & & & & & $\mathrm{K}_{-}, \mathrm{P}-$ \\
\hline & 2) & 3 & & + & + tr. & & & & & & & & & & $\mathrm{K}-, \mathrm{P}_{-}$ \\
\hline \multirow[t]{3}{*}{ U. brasiliensis } & 1) & 16 & & & & & & & + & & + & & & & $\mathrm{K}-, \mathrm{P}+$ yellow \\
\hline & 2) & 12 & & & & & & & + & & & & & & $\mathrm{K}-, \mathrm{P}+$ yellow \\
\hline & 3) & 2 & & & & & & & + & + & & & & & $\mathrm{K}-, \mathrm{P}+$ yellow \\
\hline \multirow[t]{4}{*}{ U. cornuta } & 1) & 40 & & & \pm & + & & & \pm & & & & & \pm & $\mathrm{K}+$ yellow $\rightarrow$ red \\
\hline & 2) & 5 & & & & & & + & & & & & & & $\mathrm{K}+$ yellow \\
\hline & 3) & 3 & & & + & + & \pm & & & & & & & & $\mathrm{K}+$ yellow $\rightarrow$ red \\
\hline & 4) & 2 & & & & & + & & & & & & & & $\mathrm{K}+$ yellow \\
\hline \multirow[t]{2}{*}{ U. flabelliformis } & 1) & 29 & & & & & & & + & & & & & & $\mathrm{K}-, \mathrm{P}+$ yellow \\
\hline & 2) & 3 & & & & & & & + & & + & & & & $\mathrm{K}-, \mathrm{P}+$ yellow \\
\hline \multirow[t]{2}{*}{ U. macaronesica } & 1) & 25 & + & & & & & & + & & & & & & $\mathrm{K}+$ yellowish \\
\hline & 2) & 5 & + & & & & + & & & & & & & & $\mathrm{K}+$ yellow \\
\hline \multirow[t]{2}{*}{ U. rubropallens } & 1) & 16 & & & & & & & + & + & & & & & $\mathrm{K}^{-}, \mathrm{P}+$ yellow \\
\hline & 2) & 3 & & & & & & & + & & & & & & $\mathrm{K}-, \mathrm{P}+$ yellow \\
\hline U. stipitata & 1) & 42 & & & & \pm & & + & \pm & & & & & \pm & $\mathrm{K}+$ yellow-reddish \\
\hline U. subpectinata & 1) & 26 & & & \pm & \begin{tabular}{|c|} 
\pm \\
rare \\
\end{tabular} & + & \pm & & & & & & & $\mathrm{K}+$ yellow \\
\hline \multirow[t]{2}{*}{ U. tenuicorticata } & 1) & 19 & & & & & & & + & & & & & & $\mathrm{K}-, \mathrm{P}+$ yellow \\
\hline & 2) & 6 & & & & & & & + & & + & & & & $\mathrm{K}-, \mathrm{P}+$ yellow \\
\hline U. trachyclada & 1) & 13 & & & & & & & & & & & + & & $\mathrm{K}+$ bright yellow $\rightarrow$ orangish \\
\hline Lineage 14 & 1) & 11 & & & & & + & & & & & & & & $\mathrm{K}+$ yellow \\
\hline
\end{tabular}

a brasiliensis-type of cortex based on the low A/M ratio $(<0.5)$. However, the brasiliensis-morphospecies turned out to be a complex of species with $U$. brasiliensis s.str. being characterized by an intermediate $\mathrm{A} / \mathrm{M}$ ratio (0.4-0.6\%-0.8). CMA of tenuicorticata-type (brasiliensis-type ${ }^{*}$ in Gerlach et al. 2017) characterizes species with a thin axis and a large medulla $(\mathrm{A} / \mathrm{M}<0.5)$, whereas, CMA of cornuta-type characterizes species with a larger axis and a thinner medulla $(A / M \geq 0.5)$. Beside the $\mathrm{A} / \mathrm{M}$ ratio, we introduce here the $\mathrm{M} / \mathrm{C}$ ratio that segregates species with a large medulla and a thin cortex or inversely those with a thin medulla and a thick cortex. This $\mathrm{M} / \mathrm{C}$ ratio is especially important in the Usnea cornuta aggr. where it is an important diagnostic character. $\mathrm{M} / \mathrm{C}$ ratio data are here especially important to separate $U$. brasiliensis from the $U$. flabelliformis/ tenuicorticata group. The same is true with the A/M ratio. Figure 4 shows quite clearly (no superposition of standard deviations) the differences between the former species. Table 1 and Figure 4 summarize the CMA data for all species treated here.

Furthermore, we are fully aware that this treatment is based on a small number of specimens analyzed with molecular tools. As a consequence and because of the high morphological variability of species in Usnea, the few specimens analyzed with molecular data might not represent the full variability of the species. Therefore, future testing with more material collected in a broader geographical area will likely be required to emend the descriptions.

\section{Distribution}

The sampling for each species is far from being complete. More collection worldwide will be needed to have a better idea of the distribution of these species. However, we can already see that for instance $U$. arianae, $U$. cornuta and $U$. subpectinata display an intercontinental distribution, occurring in Europe and on the American continent. Transoceanic long-distance dispersal was already reported by Gerlach et al. (2019) for the Usnea cornuta aggr. and for other Parmeliaceae lichens (Amo de Paz et al. 2011; Fernández-Mendoza et al. 2011). Long-distance dispersal (LDD) of vegetative diaspores can occur via wind (Galloway \& Aptroot 1995; Geml et al. 2010; Muñoz et al. 2004) or birds (Bailey \& James 1979; Lewis et al. 2014) and might be responsible for the present distribution of the former lineages. The distribution and habitat are discussed under each species treated in this study.

\section{The Usnea brasiliensis s.I. species group}

Among the species of $U$. cornuta aggr., this artificial group is defined by the presence of protocetraric acid, \pm psoromic acid, \pm fumarprotocetraric acid both belong to $\beta$-orcinol 

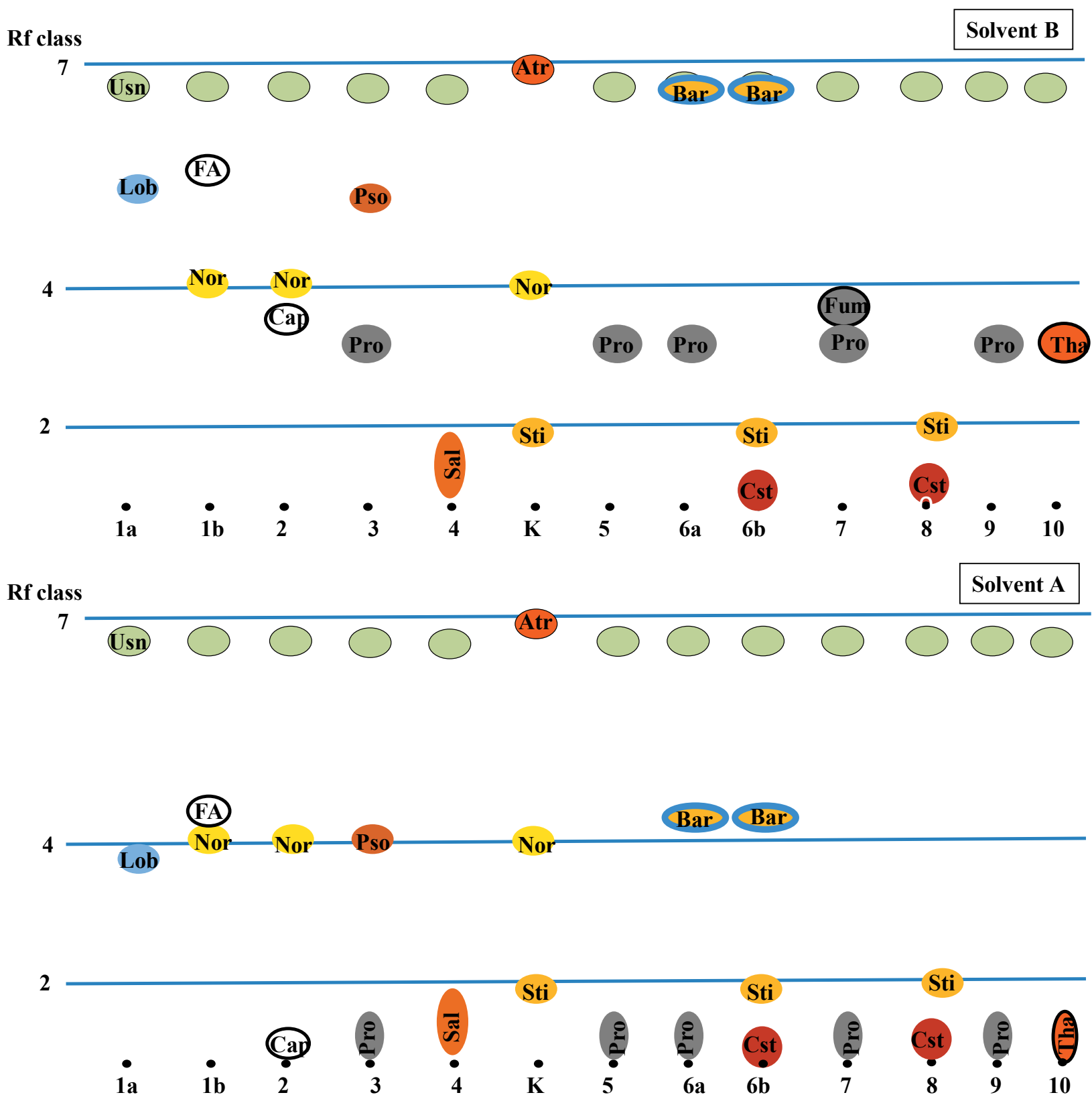

Figure 3. TLC spots of diagnostic lichen substances detected in the Usnea cornuta aggr. (solvents A and B). Control with norstictic acid (Rf class 4) and atranorin (Rf class 7) is shown in the middle column (K). The spot of usnic acid is shown in all columns as a standard except in the control column. Fatty acids are indicated by a white spot encicled with a bold line (fatty acid is only visible on wet TLC plate). The following lichen substances are shown: Atr = atranorin, Bar = barbatic acid, Cap = caperatic acid, Cst $=$ constictic acid, FA $=$ unknown fatty acid, Fum $=$ fumarprotocetraric acid, Lob $=$ lobaric acid, Nor $=$ norstictic acid, Pro $=$ protocetraric acid, Pso $=$ psoromic acid, Sal $=$ salazinic acid, Sti $=$ stictic acid, Tha $=$ thamnolic acid, Usn = usnic acid. The numbers correspond to the following species: $1 \mathrm{a}$ and $1 \mathrm{~b}-U$ snea arianae; 2 - U. boomiana; 3 -U. brasiliensis; 4 - U. cornuta; 5 -U. flabelliformis; $6 \mathrm{a}$ and $6 \mathrm{~b}-U$. macaronesica; 7 - U. rubropallens; 8 - U. subpectinata; 9 - U. tenuicorticata; 10 - U. trachyclada; $\mathrm{K}$ - Cladonia symphycarpia.

depsidones, and the absence of other depsidones in the medulla (U. brasiliensis s.l. morphospecies in Gerlach et al. 2019).

Phylogenetic analysis revealed six distinct lineages (lineages $2,4,7,11,12$ and 16 ) associated with protocetraric acid (Gerlach et al. 2019). A posteriori detailed morphological and anatomical analysis of each of these lineages revealed distinct morphological and anatomical characteristics. Lineages 2 and 4 sensu Gerlach et al. (2019) that cluster here together are described as a new species, Usnea tenuicorticata. Lineage 7 is here hypothetically assigned to $U$. brasiliensis s.str. Lineage 11 and 12 correspond respectively to U. rubropallens and U. flabelliformis, two new species described here. Finally adding more material, all these lineages are genetically well supported except $U$. flabelliformis with only one specimen (Fig. 1).

Usnea brasiliensis (Zahlbr.) Motyka s.str. (Fig. 5A-F)

MycoBank MB 371015

Basionym: Usnea bornmuelleri var. brasiliensis Zahlbr., Denkschrift. Math. naturw. Classe Kais. Akad. Wiss. Wien 83: 183. 1909. 

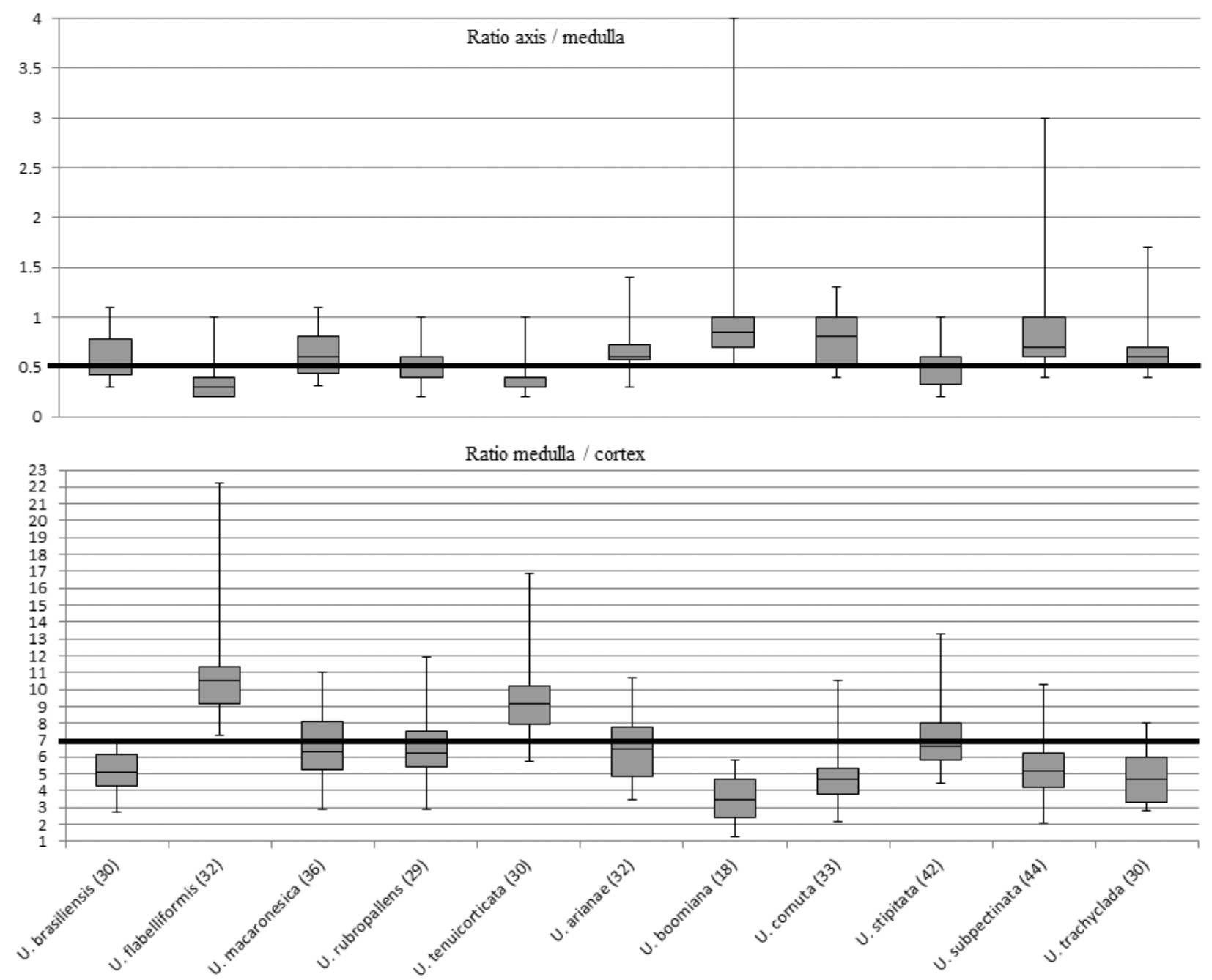

Figure 4. Axis/medulla ratio and medulla/cortex ratio; standard deviations as wide bars; extreme values as lines; numbers in parentheses = number of specimens measured.

Type: [Brazil], São Paulo, near Lagoas, Exp. Acad. Vindobon, 1901, Schiffner (W! - holotype). Lich. Gen. Usnea Stud. Monogr. Pars Syst. 2(1): 504. 1937. Chemistry: usnic, protocetraric and psoromic acids (chemistry by Clerc in 1996$) . \% \mathrm{C} / \mathrm{M} / \mathrm{A}$ : $6.5 / 38.5 / 10, \mathrm{~A} / \mathrm{M}=0.3, \mathrm{M} / \mathrm{C}=6.4$.

Epitype: [Brazil], Minas Gerais, Gonçalves, around Chalé Canário, Restaurante três irmãs, on bark, $22^{\circ} 43^{\prime} 56.75^{\prime \prime} \mathrm{S}$, $45^{\circ} 52^{\prime} 46.67^{\prime \prime} \mathrm{W}, 1604 \mathrm{~m}$. Juin 2016, A. Gerlach \& R. Penati 2016/P1-3 (G! - epitype, designated here; MycoBank MBT 392766; GenBank: MF669806); Chemistry: usnic, protocetraric and psoromic acids. $\% \mathrm{C} / \mathrm{M} / \mathrm{A}: 8.5 / 32 / 18, \mathrm{~A} / \mathrm{M}=0.6, \mathrm{M} / \mathrm{C}=3.7$.

$=$ ? Usnea bornmüelleri var. brasiliensis f. inactiva Zahlbr. Denkschr. Kaiserl. Akad. Wiss., Wien. Math.-Naturwiss. K1., 83: 187. 1909; type: Brazil, ad confines Rio de Janeiro et Minas Gerais, Monte Itatiaia, 2500 m, 1901, Schiffner (W! - holotype). Chemistry: usnic acid only (two thallus tested). $\% \mathrm{C} / \mathrm{M} / \mathrm{A}$ : $6 / 37 / 14, \mathrm{~A} / \mathrm{M}=0.4, \mathrm{M} / \mathrm{C}=6$.

Description ( $\mathrm{n}=31)$. Thallus shrubby, 3-7(-10) cm long, with anisotomic- dichotomous ramifications; basal part concolorous with branches, sometimes blackish near the holdfast; main branches thick, 1-2 mm diameter, often strongly irregular in longitudinal section, terete to sometimes slightly obtuse-angled in transversal section, distinctly segmented, sometimes with thick eroded annular cracks with medullary extrusion or at least medulla well visible between the segments, sometimes with regeneration's rings between the segments; segments \pm swollen to cylindrical; lateral branches distinctly constricted at attachment points, often with annular cracks at the base; terminal branches thin to thick with few ramifications; foveolae and transverse furrows absent to rarely present; maculae and pseudocyphellae absent to rarely present; papillae (initial stage of fibrils?) small and verrucose, scattered on the branches; tubercles absent (not to be mistaken with early stages of fibrils); fibrils slender, few, unevenly distributed on the whole thallus; fibercles few to numerous; soralia: a) minute, $50-120 \mu \mathrm{m}$ in diam. (Fig. 5B), with a tendency to fuse together to form larger consoralia $(-500 \mu \mathrm{m})($ Fig. $5 \mathrm{C}-\mathrm{F}), \mathrm{b})$ of irregular outline in top view, c) \pm even with cortex (Fig. $5 \mathrm{~B}$ ) to \pm stipitate in side view (Fig. 5D), d) plane to convex-efflorescent (Fig. 5E), e) with a thin cortical rim especially visible on slightly stipitate soralia (not visible when soralia are convex-efflorescent), f) sparse on main branches $\left(1 / 0.25 \mathrm{~mm}^{2}\right)$ to numerous on terminal branches $\left(10-15 / 0.25 \mathrm{~mm}^{2}\right)$, g) remaining discrete on main branches, aggregating and fusing together, forming consoralia on terminal branches; 

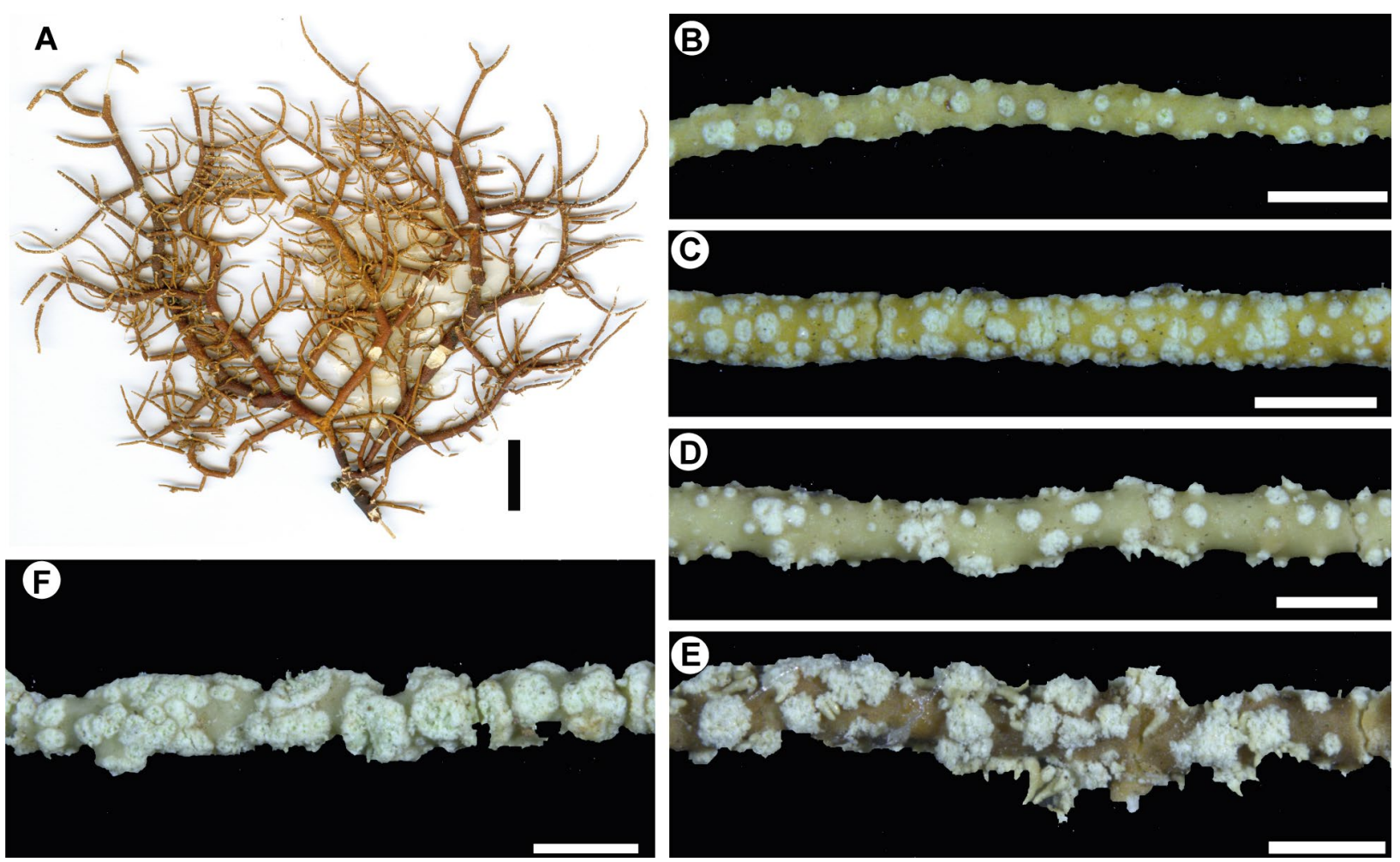

Figure 5. Usnea brasiliensis. A - shrubby thallus with constricted lateral branches (holotype: W!); B - minute young soralia (Clerc, Rojas \& Morales PC 2015/1126); C - typical consoralia even with cortex (Gerlach \& Penati 2016/P1-3, DNA 15); D - typical, minute to \pm large consoralia, \pm stipitate (Clerc, Rojas, Loza, Morales \& Valverde PC 2015/702); E - large and convex mature soralia with isidiomorphs (Kalb \& Plöbst s.n.); F - overmature, large and almost concave soralia without isidiomorphs (Gerlach \& Penati 2016/P1-3, DNA 15). Scales: A = $1 \mathrm{~mm} ; \mathrm{B}-\mathrm{F}=500 \mu \mathrm{m}$.

isidiomorphs short $(70-120 \mu \mathrm{m})$, few to numerous and covering terminal branches; isidiofibrils absent or rare; apothecia rare, terminal, $\sim 3 \mathrm{~mm}$ diameter; ascospores and pycnidia not seen; cortex shiny, of the merrillii-type, thin to moderately thick (Table 1); medulla thick (Table 1), dense to compact, distinctly two layered; axis thin (Table 1); CMA intermediate between the tenuicorticata-type and the cornuta-type (Fig. 4).

Chemistry. Chemotypes: 1) protocetraric acid, psoromic acid, \pm conpsoromic acid, \pm unknown substance grey with Rf Classes A: 4, B: 4-5, C? $(\mathrm{n}=16)$, medulla $\mathrm{K}-$, $\mathrm{P}+$ yellow $\rightarrow$ orange-reddish; soralia $\mathrm{K}+$ yellowish, $\mathrm{P}+$ yellow; 2) protocetraric acid $(\mathrm{n}=12)$, medulla $\mathrm{K}-, \mathrm{P}+$ yellow $\rightarrow$ orange-reddish; soralia $\mathrm{K}-, \mathrm{P}-; 3$ ) protocetraric acid, fumarprotocetraric acid (trace), \pm unidentified fatty acids $(\mathrm{n}=2)$, medulla $\mathrm{K}-, \mathrm{P}+$ yellow $\rightarrow$ orange-reddish; soralia $\mathrm{K}-$, $\mathrm{P}-$ (Fig. 3).

Distribution and habitat. Mentioned for South and North America (Herrera-Campos et al. 2001; Bungartz et al. 2018), Macaronesia (Pérez-Vargas et al. 2010), Japan and Taiwan (Ohmura 2001, 2012). However, its exact distribution is not known because likely confusion with the other taxa belonging to the $U$. brasiliensis morphotype (see below). In this study, we found Usnea brasiliensis in Brazil where it was corticolous in rural areas, pastures, Campos de altitude, dense rain forests and Araucaria forests between 700 and 1900 m elevation; in Costa Rica, corticolous in rural areas, pastures, mountain tropical forests or lignicolous on fences, between 1500 and 2400 m elevation; in El Salvador in rural zones and low premontane tropical forests between 1400 and $2000 \mathrm{~m}$ elevation and in Mexico in Quercus/Pinus forests between 2000 and $2200 \mathrm{~m}$ elevation.

Diagnostic notes. Among the Usnea brasiliensis morphotype, U. brasiliensis s.str. is characterized by its soralia that are minute and of irregular outline in top view (Fig. 5B), even with the cortex slightly stipitate, aggregating in larger consoralia when well developed (Fig. 5C-F). The main branches are often strongly irregular (Fig. 5A) and the ratio $\mathrm{M} / \mathrm{C}$ is smaller than 7 , highlighting a relatively thick cortex and a not too large medulla. For differences with other taxa of the brasiliensis morphospecies, see under these species.

Variation. The development of soralia is very variable from very small and isolated soralia to large consoralia aggregated on terminal branches (Fig. 5B-F). Large and convex soralia occur rarely (Fig. 5E). The density of isidiomorphs varies to a great extent as well. The presence of thick annular cracks with medullar extrusions and regeneration rings is variable too.

Discussion. Usnea brasiliensis corresponds to lineage 7 in Gerlach et al. (2019) and Figure 1.

Since the type specimen was collected in 1901, we were not able to sequence its DNA. As such, the attribution of lineage 7 to $U$. brasiliensis s.str. remains hypothetical. We based our decision on the morphology of soralia and on CMA data. The type specimen of $U$. brasiliensis fits morphologically and anatomically well with the specimens representing the lineage 7 . The type specimen of 
Usnea bornmüelleri var. brasiliensis f. inactiva without secondary compounds corresponds pretty well to U. brasiliensis s.str. However, the absence of basal part introduces uncertainty in this identification.

Usnea brasiliensis was considered as an infra-specific taxon (U. cornuta subsp. brasiliensis (Zahlbr.) P. Clerc) by Clerc (2004, 2007) because of the presence of seemingly intermediate forms between both taxa. In their work on Mexican species of the $U$. cornuta aggr., Herrera-Campos et al. (2001, as U. fragilescens aggr.) disagreed with this treatment and separated both taxa at the species level. There are, however, more than one species of the U. brasiliensis morphospecies in Mexico (see under U. flabelliformis und U. tenuicorticata).

Selected specimens analyzed. BRAZIL. Minas Gerais: Gonçalves, near Chalé Canário, 22 $43^{\prime} 57^{\prime \prime} \mathrm{S}, 45^{\circ} 52^{\prime} 47^{\prime \prime} \mathrm{W}$, corticolous on bark, Mai. 2016, A. Gerlach \& R. Penati 2016/ P1-3 (G, DNA 15). Santa Catarina: Alfredo Wagner, Reserva Particular do Patrimônio Natural Rio das Furnas, trilha em torno da sede, $27^{\circ} 40^{\prime} 28.3^{\prime \prime} \mathrm{S}, 49^{\circ} 10^{\prime} 37.9^{\prime \prime} \mathrm{W}$, Mai. 2016, A. Gerlach 2016/P3 (G, DNA 204). São Paulo: Serra do Mar, Serra de Paranapiacaba, $60 \mathrm{~km}$ südwestlich von São Paulo, oberhalb von Juquitiba, in einem hellen, feuchten Urwald am Rio Juquiá, alt. 800 m, 1978, K. Kalb \& P. Plöbst s.n. (G). COSTA RICA. Province of San José: Moravia Co. Cordillera Central, Route 32, Bajo de La Hondura, Pre Montane tropical wet forest, sur divers arbres décidus, $10^{\circ} 1^{\prime} 34.74^{\prime \prime} \mathrm{N}, 81^{\circ} 0^{\prime} 40.45^{\prime \prime} \mathrm{W}, 21$ Jan.2013, P. Clerc \& C. Rojas 2016/173 (G). EL SALVADOR. Department of Santa Ana: Metapán, Parque Nacional Montecristo, chemin vers Trinifio depuis l'aire de camping 2, Low premontane tropical forest, au sol dans la forêt, à la mimite entre la forêt de nuags et la forêt de Cupressus, $14^{\circ} 24^{\prime} 9^{\prime \prime} \mathrm{N}$, $89^{\circ} 21^{\prime} 26^{\prime \prime} \mathrm{W}$, alt. $1950 \mathrm{~m}, 16$ Jan. 2013, P. Clerc, C. Rojas \& E. Morales 2015/1044 (G). MEXICO. Chiapas: Etwa 25 km NW von Comitán de Dominguez. In einem schattigen, trockenen Eichen, Kiefern-Wald, 2150 m, 19/01/1979, K. Kalb \& G. Plöbst s.n. (G)

Usnea flabelliformis A. Gerlach \& P. Clerc, sp. nov.

(Fig. 6A-G)

\section{MycoBank MB 835882}

Diagnosis: Differs from U. brasiliensis mainly in the fan-shaped often flattened strongly irregular main branches, the frequent occurrence of foveoles and/or transverse furrows, the ratio $\mathrm{M} / \mathrm{C}$ $>7$, the more distinctly stipitate soralia and its molecular phylogenetic position.

Type: Brazil, Rio Grande do Sul, São Francisco de Paula, $\sim 29^{\circ} 26^{\prime} 53.02^{\prime \prime} \mathrm{S} 50^{\circ} 35^{\prime} 1^{\prime \prime} \mathrm{W}$, exotical forest of Castanea sativa Mill., August 2014, A. Gerlach et al. 1517 (ICN 179133 - holotype, GenBank MF669810; G - isotype). Chemistry: usnic and protocetraric acids (holotype and isotype). $\% \mathrm{C} / \mathrm{M} / \mathrm{A}: 3 / 43 / 8$, $\mathrm{A} / \mathrm{M}=0.2, \mathrm{~A} / \mathrm{C}=2.9, \mathrm{M} / \mathrm{C}=13.6$ (isotype).

Description $(\mathrm{n}=32)$. Thallus shrubby and usually soft, 3-7(-10) cm long, with anisotomic-dichotomous ramifications; basal part concolorous with branches or blackish close to the holdfast, up to $5 \mathrm{~mm}$ long, often annulated and narrower than main branches (Fig. 6A); main branches thick, 1.5-3.5 mm diameter, strongly irregular, often widening and flattening when branching and taking a \pm fanshaped aspect (Fig. 6B), \pm distinctly segmented; segments swollen, obtuse-angled to flattened in cross section, often with distinct annular cracks eroded at margin, typically with medullar extrusion and cortex regeneration; lateral branches distinctly constricted, often with conspicuous annular cracks at attachment point; terminal branches thick, often strongly deformed by the stipitate soralia, with few ramifications; foveolae and transverse furrow typically present, often numerous; maculae and pseudocyphellae absent; papillae small, indistinct to verrucose few to numerous densely and regularly distributed mainly on main branches; tubercles absent; fibrils few, never numerous, slender, unevenly distributed on the whole thallus, with base slightly constricted and then easily breakable; fibercles few, never numerous; soralia (Fig. 6D-H): a) minute, $70-220 \mu \mathrm{m}$, with a tendency to aggregate without loosing their individuality or forming consoralia especially on terminal branches $(-500 \mu \mathrm{m}), \mathrm{b})$ almost circular to irregular, c) slightly to distinctly stipitate, d) plane to convex and efflorescent, e) with a thin but distinct cortical rim, f) sparse on main branches to numerous on terminal branches (8-12 soralia/0.25 $\mathrm{mm}^{2}$ ) g) mostly remaining isolated, sometimes forming consoralia especially at the end of terminal branches, h) mainly on subterminal and terminal branches; isidiomorphs few to numerous, sometimes covering the soralia on terminal parts (Fig. 6H); isidiofibrils absent to rarely present; apothecia rare $(n=4)$, terminal, with marginal fibrils; ascospores 8-7 × 5-6 $\mu \mathrm{m}$ $(\mathrm{n}=10$ spores); pycnidia not seen; cortex thin (Table 1$)$, shiny; medulla thick (Table 1), lax to dense; axis thin (Table 1). CMA of the tenuicorticata-type (Fig 4 and 6C).

Chemistry. Chemotypes: 1) protocetraric acid $(\mathrm{n}=29)$ : medulla $\mathrm{K}-$, $\mathrm{P}+$ yellow $\rightarrow$ orange-reddish, soralia $\mathrm{K}-$, $\mathrm{P}-$; 2) protocetraric, psoromic, \pm conpsoromic acids $(n=3)$, medulla $\mathrm{K}-$, $\mathrm{P}+$ yellow $\rightarrow$ orange-reddish, soralia $\mathrm{K}+$ yellowish, P+ yellow (Fig. 3).

Etymology. Refers to the fan-shaped primary branches.

Distribution and habitat. Usnea flabelliformis was found to occur in Brazil, corticolous in rural areas, pastures, dense rain forests, Campos de altitude and Pine or Araucaria, between 700 and 1900 m elevation; in Costa Rica, corticolous in rural areas, pastures, mountain tropical forests or lignicolous on fences, between 1500 and 2800 m elevation; in El Salvador in rural areas, pastures and Pine-Oak forests between 1500 and $1800 \mathrm{~m}$ elevation and in Mexico in a Quercus/Pinus forest at $2200 \mathrm{~m}$ elevation. Usnea flabelliformis was found to occur side by side with $U$. brasiliensis s.str.

Diagnostic notes. Among the brasiliensis morphospecies, U. flabelliformis is characterized by the fan-shaped (Fig. 6B) and often flattened strongly irregular main branches with foveoles or transverse furrow (Fig. 6A-B), the distinctly constricted lateral branches (Fig. 6A-B), the tenuicorticata-type of CMA with low $\mathrm{A} / \mathrm{M}$ and the ratio $\mathrm{M} / \mathrm{C}>7$ (Figs 4, 6C), as well by the mostly distinctly stipitate soralia on subterminal and terminal branches (Fig. 6E-F).

Variation. Soralia are very variable in U. flabelliformis, small, punctiform, remaining more or less isolated (Fig. 

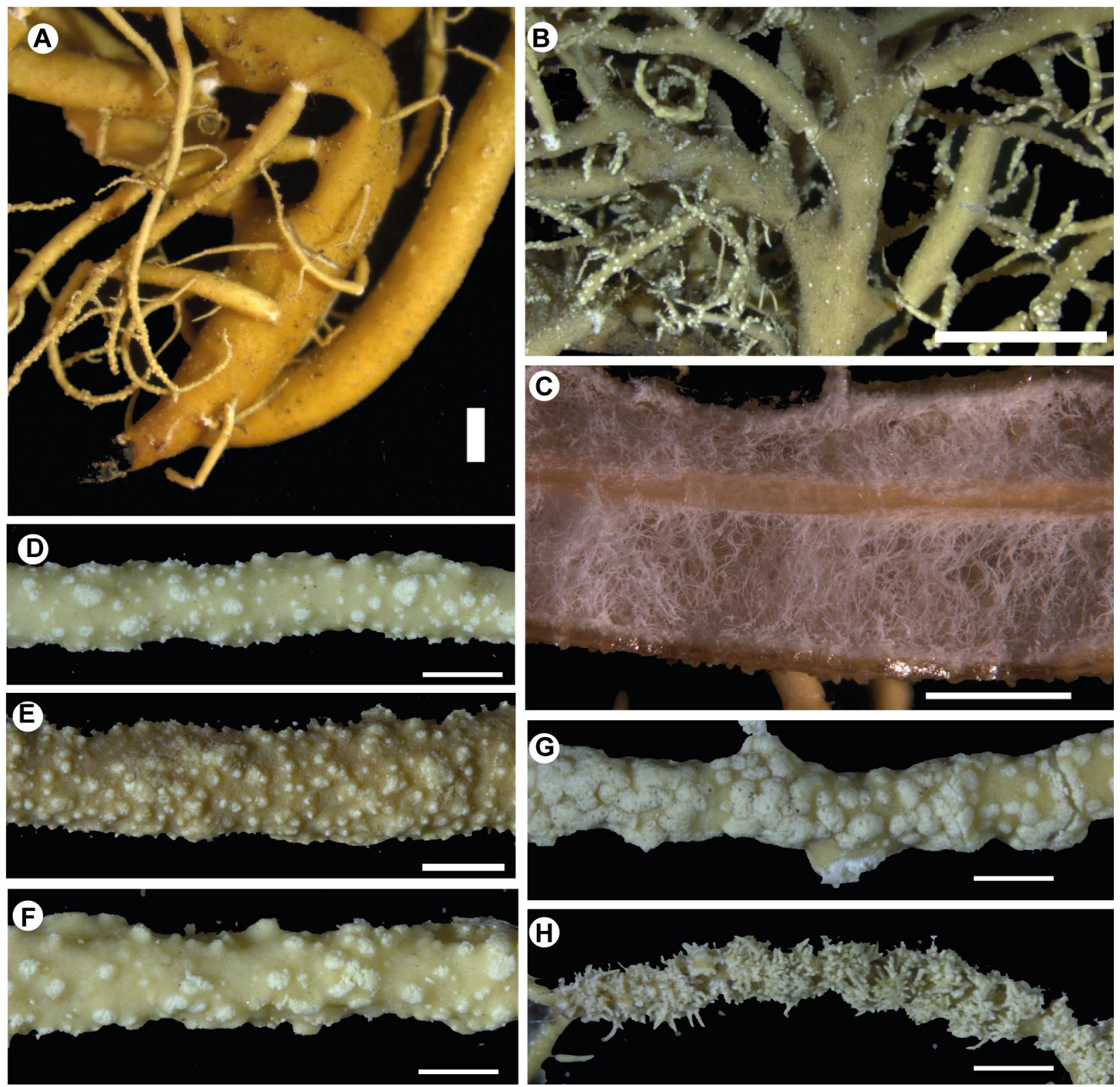

Figure 6. Usnea flabelliformis. A - strongly irregular main branches with narrower base (Gerlach 1259e); B - fan-shaped main branches with foveolae and distinctly constricted lateral branches (Gerlach 1010); C - CMA of tenuicorticata-type, with low A/M and high M/C (Gerlach 1405); D - young, small, punctiform soralia (Gerlach 1517, DNA 4873); E, punctiform and slightly stipitate soralia remaining more or less isolated (Gerlach 1172a); F, larger stipitate soralia sometimes fusing together to form consoralia (Gerlach 1517, DNA 4873); G, branches covered with typical and mature consoralia (Clerc \& Rojas 2015/358); H, terminal branches with consoralia covered with isidiomorphs (Gerlach \& Alves 1328d). Scales: $\mathrm{A}, \mathrm{B}=2 \mathrm{~mm} ; \mathrm{C}=1 \mathrm{~mm} ; \mathrm{D}-\mathrm{H}=500 \mu \mathrm{m}$.

$6 \mathrm{D}-\mathrm{E})$ or fusing together to build large consoralia (Fig. 6F-H). Typically distinctly stipitate (Fig. 6E-F), they are sometimes even with the cortex (Fig. 6G) as in $U$. cornuta s.str., or only slightly stipitate (Fig. $6 \mathrm{E}-\mathrm{F}$ ), as in $U$. brasiliensis s.str. The basal part is variable too, mostly concolorous with main branches, but often blackish near the holdfast in many specimens. The size and the density of papillae are very variable in this taxon as well.

Discussion. Usnea flabelliformis corresponds to lineage 12 in Gerlach et al. (2019) and Figure 1. Unfortunately, we were not able to obtain good quality DNA except from only one specimen (Holotype specimen). By chance, however, this collection contains two mature specimens with well developed characters. Usnea flabelliformis differs from $U$. brasiliensis s.str. mainly by the following two characters: 1 . The high ratio $\mathrm{M} / \mathrm{C}(>7)$ and low $\mathrm{A} / \mathrm{M}$ $(<0.5)$ meaning a thinner cortex and a wider medulla in $U$. flabelliformis (Fig. 6C); 2. The fan-shaped and often flattened strongly irregular main branches with foveoles or transverse furrows (Fig. 6A-B) opposite to the \pm swollen and cylindrical main branches that are terete to sometimes slightly obtuse-angled in transversal section, usually without foveoles/transverse furrows (Fig. 5A) in $U$. brasiliensis. Moreover the soralia of $U$. flabelliformis are usually more distinctly stipitate. Finally, psoromic acid is more frequent in U. flabelliformis $(52.4 \%$ of the specimens analyzed) than in U. brasiliensis (7\%). Usnea intumescens is an eastern Asiatic species with punctiform 
soralia and psoromic acid in the medulla (Ohmura 2001). However, it does not seem to belong to the U. cornuta aggr. since the lateral branches are not constricted but broadened at their base. Moreover, this species differs from $U$. flabelliformis by the thicker central axis (Ohmura 2001) and a lower M/C ratio. Finally, the latter species differs by 31 nucleotide positions in the ITS sequences. For differences with other taxa of the brasiliensis morphospecies, see under these species.

Selected specimens analyzed. BRAZIL. Paraná: Rio Branco do Sul, beira da rodovia, 2012, A. Gerlach, E. Gumboski \& F. Beilke 804 (ICN). Rio Grande do Sul: Cambará do Sul, Parque Nacional dos Aparados da Serra, beira de mata em ramos, 1986, M. Fleig 2839 (ICN 71313). Santa Catarina: Alfredo Wagner, Reserva Particular do Patrimônio Natural Rio das Furnas, 2014, A. Gerlach 1259e (ICN). São Paulo: Zwischen Guapira und Apiaí, in einem kleinen Pinus-Forest, an Pinus spec., alt. 800 m, 23 Aug. 1980, K. Kalb s.n. (G). COSTA RICA. Province of Puntarenas: Coto Brus Co. Las Tablas, Finca Las Tablas, $1771 \mathrm{~m}, 8^{\circ} 56^{\prime} 47.2^{\prime \prime} \mathrm{N}, 83^{\circ} 44^{\prime} 24.8^{\prime \prime} \mathrm{W}$, sur une souche morte dans la pente, 2 Feb. 2013, P. Clerc \& C. Rojas 2015/115 (G). EL SALVADOR. Department of Santa Ana: Metapán, Parquen Nacional Montecristo, alt. 1745 m, $14^{\circ} 23^{\prime} 36.5^{\prime \prime} \mathrm{N}, 89^{\circ} 21^{\prime} 38.54^{\prime \prime} \mathrm{W}$, sur branche de Lyciloma auritum, 15 Jan. 2013, P. Clerc, C. Rojas \& E. Morales 2015/950 (G). MEXICO. Chiapas: etwa $25 \mathrm{~km}$ NW von Comitán de Dominguez. In einem schattigen, trockenen Eichen, Kiefern-Wald, alt. 2150 m, 25 Jan.1979, K. Kalb \& G. Plöbst s.n. (G).

Usnea macaronesica P. Clerc, The Lichenologist 38: 202. 2006.

(Fig. 7A)

MycoBank MB 521712

Type: [Spain], Canary islands, El Hierro, Frontera, El Golfo, Montana Hoya de la Vaca, $500 \mathrm{~m}$ au nord du Mirador de Jinama, en descendant sur El Golfo, 1200-1220 m, sur Erica arborea dans le Fayal- Brezal, dans la pente escarpé en exp. SW, 1 Octobre 1986, P. Clerc 11763 (G! - holotype; BM, UPS - isotype). Chemistry: usnic and barbatic acids (holotype). $\% \mathrm{C} / \mathrm{M} / \mathrm{A}$ : 6/34/20 (holotype), $\mathrm{M} / \mathrm{C}=5.7$.

$=$ Usnea subglabrata Truong \& P. Clerc, The Lichenologist 48(1): 71-93. 2016, syn. nov.

Type: Bolivia, La Paz, $16.291639^{\circ} \mathrm{S}, 67.860556^{\circ} \mathrm{W}, 3132 \mathrm{~m}$, bosque de neblina montano en transición con matorral, sobre ramas de árboles pequeños, 2007, Truong 2978 (LBP - holotype; G! - isotype, DNAcode: 25BO). Chemistry: usnic, stictic, constictic, menegazziaic, barbatic, traces of norstictic acids. $\% \mathrm{C} / \mathrm{M} / \mathrm{A}: 5.0 / 31.5 / 27.0 . \mathrm{M} / \mathrm{C}=6.3$.

Description. Detailed description and illustrations are available in Clerc (2006) and Truong \& Clerc (2016, as U. subglabrata).

Chemistry. Chemotypes: 1) protocetraric and barbatic acids $(\mathrm{n}=25)$ : medulla $\mathrm{K}-, \mathrm{P}+$ yellow $\rightarrow$ orange-reddish; soralia $\mathrm{K}-, \mathrm{P}-; 2)$ barbatic and stictic acids $(\mathrm{n}=5)$ : medulla: $\mathrm{K}-, \mathrm{P}+$ yellow, soralia $\mathrm{K}-$, $\mathrm{P}-$ (Fig. 3).

Distribution and habitat. Amphi-atlantic distribution in the Canary Islands, the Azores and Eastern North America (USA, Canada) (Clerc 2006, 2011) and in South America (Truong \& Clerc 2016, as U. subglabrata). In our study, this species was found in Brazil growing often on shrubs-trees (Baccharis spp., Berberis spp.) in Campos de Altitude, Araucaria and mountain cloud forests, between 1800 and 2400 m elevation; in Costa Rica in a rural area (forest regeneration zone) corticolous on Alnus acuminata at 1870 m elevation and in Guatemala in an Alnus forest intermixed with Pine trees at 2350 m elevation.

Diagnostic notes. In the Usnea brasiliensis aggr., $U$. macaronesica is characterized by the large \pm excavate soralia ( $>1 / 2$ branch diameter, not to be confused with consoralia) (Fig. 7A) often with isidiomorphs, the shortly black pigmented basal part and the lax and broad medulla with barbatic acid.

Variability. The Brazilian specimens show a much larger variation in the soralia morphology than the Macaronesian specimens. Some specimens have soralia that are even with the cortex distinctly convex while others have concave soralia of the lapponica-type (Clerc 1987a) with all the possible intermediates. Moreover, isidiomorphs might be totally absent to numerous.

Discussion. Usnea macaronesica corresponds to lineage 16 (Fig. 1). Because of its distinctly constricted lateral branches, a tenuicorticata-type of CMA and protocetraric acid often as the main substance in the medulla, we decided to include $U$. macaronesica in our study of the $U$. brasiliensis group. The identity of the Brazilian specimens is confirmed by the specimen PT_KJ406283 collected in the Açores and nested inside the Brazilian lineage. Moreover, the type specimen of U. subglabrata (DNA 25B0) from Bolivia (Truong \& Clerc 2016), is nested inside the macaronesica lineage (Fig. 1) and thus considered here as a synonym of the latter.

Usnea subglabrata is characterized by excavate soralia, without isidiomorphs and the presence of barbatic and stictic acids in the medulla (Truong \& Clerc 2016). These characters belong to the variation of $U$. macaronesica. Usnea macaronesica is chemically variable as well since we found a new chemotype (barbatic and protocetraric acids) present so far only in Brazil and clustering with good support together with the barbatic-stictic acids chemotype (Figs 1-2). Usnea brasiliensis and U. flabelliformis have punctiform soralia often fusing into large consoralia (Figs 5-6) whereas the large soralia of $U$. macaronesica remain isolated (Fig. 7A). Usnea glabrata, another species with constricted lateral branches and protocetraric acid in the medulla have a smooth cortex without papillae and soralia never with isidiomorphs. Moreover, this species does not produce barbatic acid in the medulla. For differences with other taxa of the $U$. brasiliensis aggr. see under these taxa.

Selected specimens analyzed. BRAZIL. Minas Gerais: Serra da Mantiqueira, Itamonte, Parque Nacional Itatiaia, on shrubs, $22^{\circ} 22^{\prime} 25^{\prime \prime} \mathrm{S}, 44^{\circ} 42^{\prime} 13^{\prime \prime} \mathrm{W}$, alt. $2430 \mathrm{~m}, 23$ Nov. 2017, P. Clerc, A. Gerlach \& M. Dal-Forno 17/134 (G, DNA 240). Rio Grande do Sul: Cambará do Sul, Parque Nacional Aparados da Serra, Cânion Itaimbezinho, 14 Mar 2014, A. Gerlach \& C. Alves 1408 (ICN). Santa Catarina: Urubici, São Joaquim National Park, Morro do Baú, along the road to the cemetary, on branches of small shrubs, $28^{\circ} 09^{\prime} 49^{\prime \prime} \mathrm{S} 49^{\circ} 36^{\prime} 30^{\prime \prime} \mathrm{W}$, alt. $1730 \mathrm{~m}, 19$ Nov. 

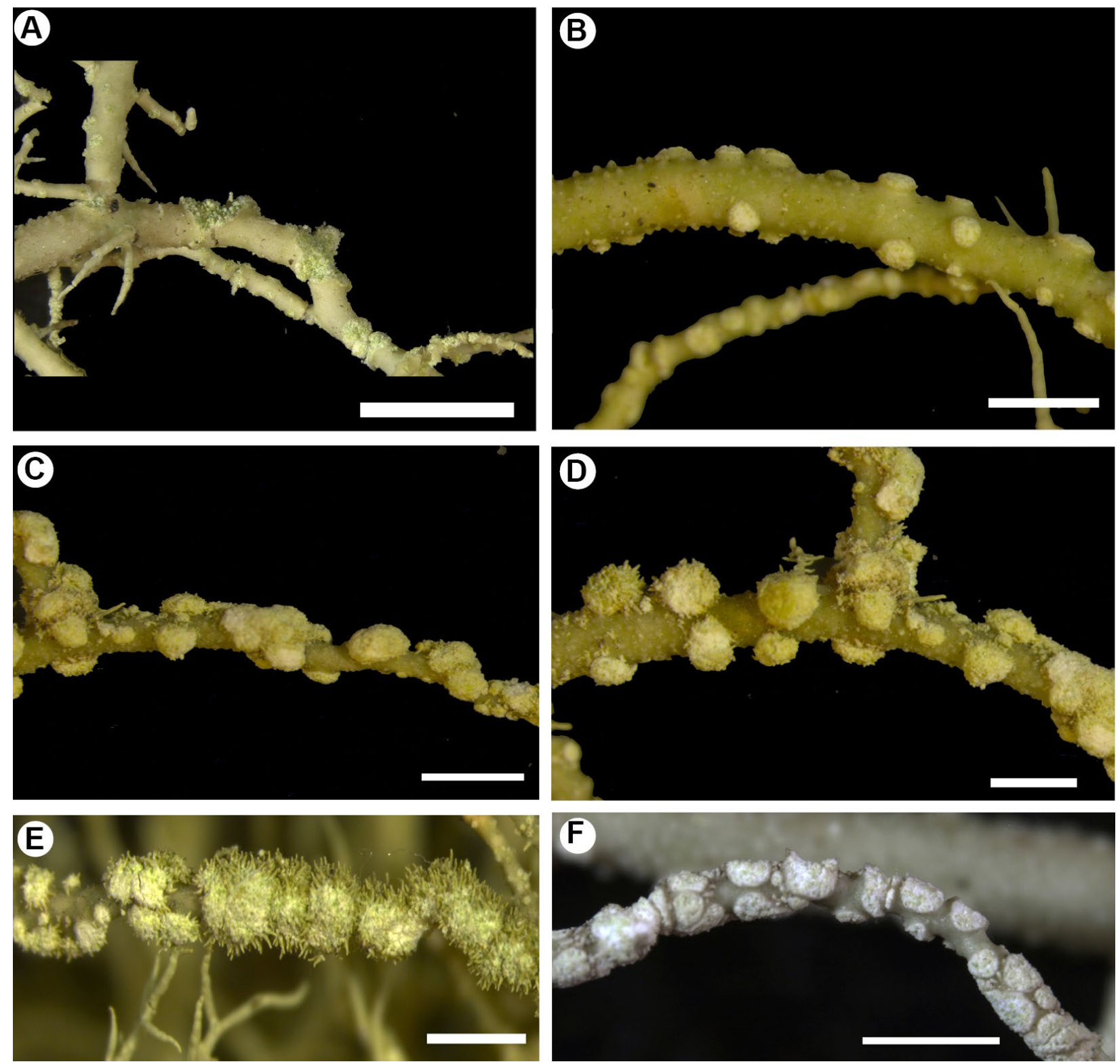

Figure 7. Usnea macaronesica (A; Gerlach, Clerc \& Dal-Forno 2485) and U. boomiana (B-F; Gerlach, Clerc \& Dal-Forno 2455, DNA 395). A - large and excavate soralia; B - young stipitate, well delimited soralia; C - large and capitate soralia; D - typical large and capitate mature soralia with isidiomorphs; E - aggregating soralia with many isidiomorphs on terminal branches; F - overmature large, plane to \pm concave soralia without isidiomorphs. Scales: A-F $=500 \mu \mathrm{m}$.

2017, P. Clerc \& A. Gerlach 17/74 (ICN 195519, DNA 280). São Paulo, Serra da Mantiqueira, Campos do Jordão, road passed Pico do Itapeva, $22^{\circ} 45^{\prime} 51^{\prime \prime} \mathrm{S}, 45^{\circ} 31^{\prime} 17^{\prime \prime} \mathrm{W}$, alt. $1860 \mathrm{~m}$, on bark, 28 Nov. 2017, P. Clerc, A. Gerlach \& M. Dal-Forno 17/334 (G, DNA 246). SPAIN. Canary islands: Tenerife, Parque Natural Anaga, Pico del Ingles, $28^{\circ} 26^{\prime} 45.02^{\prime \prime} \mathrm{N}, 16^{\circ} 21^{\prime} 52.52^{\prime \prime} \mathrm{W}$, alt. 1000 m, Laurisilva, sur branche d'Erica arborea, 21 Oct. 2018, D. Nunes s.n. (G). COSTA RICA. Province of San José: Pérez Zeledon Co. Cordillera de Talamanca, Parque Nacional Chirripó, 9²7'51.4"N, 8334'53.6"W, alt. $1801 \mathrm{~m}, 13$ Sep. 2014, P. Clerc \& G. Loza 2015/605 (G). EL SALVADOR. Department of Santa Ana: Metapán, Parque Nacional Montecristo, $14^{\circ} 24^{\prime} 9^{\prime \prime} \mathrm{N}, 89^{\circ} 21^{\prime} 36^{\prime \prime} \mathrm{W}$, alt. $1950 \mathrm{~m}$, sur un décidu, dans la forêt, à la limite entre la forêt de nuages et la forêt de Cupressus, 16 Jan. 2013, P. Clerc, C. Rojas \& E. Morales 2015/1092 (G). GUATEMALA. Chimaltenango: Etwa $5 \mathrm{~km}$ nordwestlich von Santa Apolonia, in einem lichten feuchten Erlenwäldchen, untermischt mit Kiefern, alt. 2350 m, 17 Jan. 1979, K. Kalb \& G. Plöbst s.n. (G).
Usnea rubropallens A. Gerlach \& P. Clerc, sp. nov.

(Fig. 8A-C)

MycoBank MB 836034

Diagnosis: Differs from $U$. brasiliensis (Zahlbr.) Motyka by the presence of a faint orange and diffuse cortical/subcortical pigment, especially close to the basal part and by its molecular phylogenetic position.

Type: Brazil, Santa Catarina, Reserva Particular do Patrimônio Natural Rio das Furnas, $27^{\circ} 40^{\prime} 28.3^{\prime \prime} \mathrm{S}, 49^{\circ} 10^{\prime} 37.9^{\prime \prime} \mathrm{W}$, alt. 900 m, corticolous, 14 Mai 2016, A. Gerlach, G. Giovanka \& R. Rizzaro 2016/P46 (ICN - holotype, GenBank: MF669848; $\mathrm{G}$ - isotype). \%C/M/A: 7/36/14, A/M: 0.4, M/C: 5.1 (holotype); Chemistry: usnic, protocetraric and fumarprotocetraric acids, two unknown substances Rf classes A/B: 4/4-5 and 3/5-6 (holotype and isotype). \%C/M/A: 5/35.5/19, A/M: 0.7, M/C: 7.1 (isotype). 
Description $(\mathrm{n}=28)$. Thallus shrubby to subpendulous, usually soft, 4-8(-9) cm long, with anisotomic-dichotomous ramifications; basal part concolorous with main branches or blackish close to the holdfast, sometimes with a wine-red pigment, often annulated and narrower than main branches (Fig. 8A); main branches 1.4-3.6 mm diameter, often strongly irregular longitudinally, distinctly segmented, with medulla distinctly visible between segments; segments \pm terete to slightly flattened in transversal section, \pm inflated; lateral branches slightly to distinctly constricted; terminal branches thick, often strongly deformed by the stipitate soralia, with few ramifications; foveolae and transverse furrows often present, sometimes only as small depressions in the cortex $(40 \times)$; pseudocyphellae and maculae absent; papillae (initial stage of fibrils?) small and verrucose, scattered on the branches; tubercles absent; fibrils long and slender, often numerous, irregularly arranged; fibercles numerous, often on main branches too; soralia (Fig. 8C-D): a) punctiform, mostly 70-250 $\mu \mathrm{m}$, sometimes enlarging up to $450 \mu \mathrm{m}, \mathrm{b}$ ) of irregular shape (top view), c) distinctly stipitate giving an irregular and nodulose aspect to the apices (side view), d) surface often convex and efflorescent, e) without cortical rim, f) sparse to dense $\left(6-12 / 0.25 \mathrm{~mm}^{2}\right)$, g) mostly remaining isolated, sometimes aggregating rarely fusing together, almost never forming large consoralia, h) secondary and terminal branches; isidiomorphs always present, usually numerous, giving an efflorescent aspect to the soralia; isidiofibrils usually numerous, up to $0.5 \mathrm{~mm}$ long, sometimes densely covering the branches; apothecia rare, 3-4 mm large, terminal, with a whitish margin (medullary excretion); ascospores 7.5-8.5 × 5-6.5 $\mu \mathrm{m}$ $(\mathrm{n}=9)$; pycnidia not seen; cortex thin (Table 1), shiny in section, fragile, of the ceratina-type, with longitudinal and transversal cracks, with a faint orange reddish and diffuse pigment in irregular patches, sometimes on main and secondary branches as well; medulla thick (Table 1), dense, mostly one layered, sometimes with a orangish-reddish subcortical pigment; axis thin (Table 1). CMA intermediate between the tenuicorticata and the cornuta-type (Figs 4, 8B).

Chemistry. Chemotypes: 1) protocetraric acid, fumarprotocetraric acid, \pm an unknown gray spot $(\mathrm{Rf}$ classes $\mathrm{A} / \mathrm{B} / \mathrm{C}$ : 4/4-5/5-6), \pm an unknown gray spot ( Rf classes A/B/C: 2/5-6/?) $(\mathrm{n}=16)$, medulla $\mathrm{K}-, \mathrm{P}+\mathrm{red} ; 2)$ protocetraric acid $(\mathrm{n}=3)$, medulla $\mathrm{K}-, \mathrm{P}+$ red (Fig. 3).

Etymology. Refers to the presence of a pale orangish-reddish pigment in the cortex and/or in the medullary subcortical area.

Distribution and habitat. This species was found in Brazil growing mainly on twig and bark of Araucaria angustifolia in the Reserva Particular do Patrimônio Natural Rio das Furnas (Santa Catarina State) at above 900 meters elevation and in Costa Rica, on old stumps in
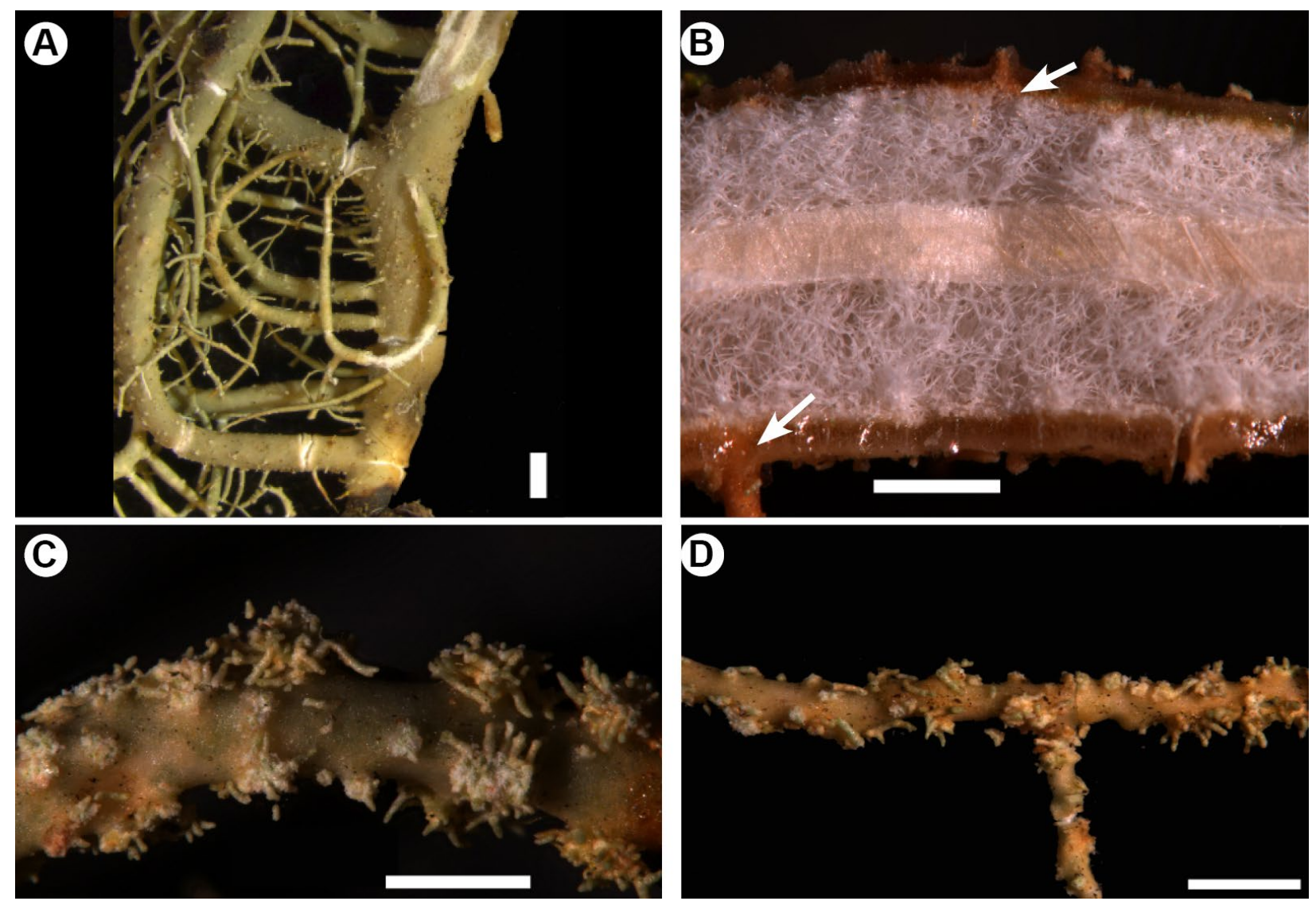

Figure 8. Usnea rubropallens. A - basal part with a faint orange pigmentation and irregular main branches (Gerlach 2016/P50); B - faint and thin layer of pale orangish subcortical pigmentation (white arrow) (Gerlach 2016/P46, holotype); C - efflorescent, more or less nodular soralia on terminal branches (Gerlach 2016/P50); D - efflorescent, punctiform soralia on terminal branches with orange pigmented zones (Gerlach 2016/ P46, holotype). Scales: A, D $=2 \mathrm{~mm}$; B, C $=500 \mu \mathrm{m}$. 
rural areas and corticolous on Alnus acuminata or lignicolous on fences in mountainous areas between 1500 and 2000 m elevation.

Diagnostic notes. Usnea rubropallens is characterized by the yellow-orangish pigmented cortical/subcortical patches (Fig. 8A-B) sometimes better observed close to the basal part, by the distinctly stipitate and efflorescent punctiform soralia giving a nodulose irregular aspect to the terminal branches (Fig. 8C-D), by the isidiomorphs that are always present, (Fig. 8D), by the frequent occurrence of isidiofibrils, by the presence of long and slender fibrils and by the frequent presence of fumarprotocetraric acid ( $85 \%$ of the specimens analyzed) in addition to protocetraric acid in the medulla (Table 2).

Variation. The intensity of cortical orange reddish pigmentation is variable, from often present and covering almost the whole thallus to very faint and present only close to the basal part (two specimens from Costa Rica). Soralia might remain distinctly stipitate and \pm punctiform or enlarge and become \pm excavate. Fibrils might be present only on one or two branches or very frequent on most of the branches.

Discussion. Usnea rubropallens corresponds to lineage 11 in Gerlach et al. (2019) and Figure 1. It differs from all taxa of the $U$. brasiliensis aggr. by the presence of the cortical/subcortical orange-reddish pigment. Usnea moreliana Motyka is another species with constricted lateral branches and a reddish cortical pigment (Truong \& Clerc 2016, as U. rubricornuta). However, the pigment of $U$. moreliana is reddish, not orangish and the medulla is $\mathrm{K}-, \mathrm{P}-$, with terpenoids in the medulla.

Usnea rubropallens forms a well supported lineage (Figs 1-2) unrelated both to U. cornuta and to U. moreliana (see Fig. 1, in Gerlach et al. 2019).

Selected specimens analyzed. BRAZIL. Santa Catarina: Alfredo Wagner, Reserva Particular do Patrimônio Natural Rio das Furnas, Bosque das Araucarias, sobre A. angustifolia, 2016, A. Gerlach et al. 2016/P37 (G). COSTA RICA. Province of Alajuela: San Carlos Co., Cordillera Central, Parque National del Agua, Juan Castro Blanco, lisière de forêt, on Alnus sp., $10^{\circ} 15^{\prime} 14.24^{\prime \prime} \mathrm{N}, 84^{\circ} 21^{\prime} 58.26^{\prime \prime} \mathrm{W}$, alt. $1867 \mathrm{~m}, 2014$, P. Clerc et al. 2015/695 (G)

Usnea tenuicorticata P. Clerc \& A. Gerlach, sp. nov. (Fig. 9A-H)

\section{MycoBank MB 836035}

Diagnosis: Differs from U. brasiliensis by thinner cortex $(\leq 5.4)$, the higher $\mathrm{M} / \mathrm{C}$ values $(>7)$, soralia that enlarge at maturity $(>1 / 2$ branch diameter) appearing almost circular in shape and by its molecular phylogenetic position.

Type: Portugal, Madeira, Ribeiro Frio, Miradores dos Balcöes, $32^{\circ} 44^{\prime} 24.7^{\prime \prime} \mathrm{N}, 16^{\circ} 53^{\prime} 24.9^{\prime \prime} \mathrm{W}, 828 \mathrm{~m}$., corticolous on a fallen Castanea tree, 8 October 2009, P. Clerc G00285250 (Gholotype). Chemistry: usnic and protocetraric acids. $\% \mathrm{C} / \mathrm{M} / \mathrm{A}$ : 3/38.5/17, $\mathrm{A} / \mathrm{M}=0.4, \mathrm{M} / \mathrm{C}=11.8$. GenBank accession code (ITS): JQ837294.
Description $(n=30)$. Thallus shrubby and often soft, 4-7(-10) cm long, with distinct anisotomic-dichotomous ramifications; basal part concolorous with branches or \pm blackish close to the holdfast, usually narrower than main branches; main branches thick, 1.2-2.6 mm diameter, strongly irregular, often sausage-like or slightly fan-shaped (Fig. 9H), distinctly segmented; segments swollen, usually circular in section, rarely obtuse-angled in cross section, sometimes with distinct, but sparse, annular cracks eroded at margin with or without medullar extrusion; lateral branches distinctly constricted; terminal branches \pm thin with few ramifications; foveolae and transverse furrows sometimes present; maculae present on young thalli; pseudocyphellae absent; papillae small and verrucose to indistinct and difficult to observe $(40 \times)$, few to numerous, on main and secondary branches; tubercles absent; fibrils few, never numerous, slender, unevenly distributed on the whole thallus; fibercles often numerous; soralia (Fig. 9A-G): a) minute, 60-120 $\mu \mathrm{m}$ to large at maturity, 200-500(-1000) $\mu \mathrm{m}$, sometimes extending around the branches, especially in terminal parts, b) irregular to almost circular when mature, with a thin hardly visible cortical rim, c) even with cortex to slightly stipitate, d) plane to convex and sometimes efflorescent, e) absent or sparse on main branches, numerous on secondary and terminal branches (3-6 soralia/ $\left.0.25 \mathrm{~mm}^{2}\right), \mathrm{f}$ ) remaining isolated, rarely aggregating together, g) distributed mainly on secondary and terminal branches; isidiomorphs few to numerous sometimes covering the soralia on terminal parts; isidiofibrils rare; apothecia rare; pycnidia not seen; cortex thin (Table 1), shiny; medulla thick (Table 1), lax to dense, two layered; axis thin (Table 1). CMA of the tenuicorticata-type (Figs 4, 6C).

Chemistry. Chemotypes: 1$)$ protocetraric acid $(n=19)$; medulla $\mathrm{K}-$, $\mathrm{P}+$ yellow $\rightarrow$ orange-reddish, soralia $\mathrm{K}-$, $\mathrm{P}-$; 2 ) protocetraric, psoromic, \pm conpsoromic acids $(\mathrm{n}=10)$; medulla $\mathrm{K}-$, $\mathrm{P}+$ yellow $\rightarrow$ orange-reddish, soralia $\mathrm{K}+$ yellowish (only when psoromic acid concentration is high enough), $\mathrm{P}+$ yellow (Fig. 3).

Etymology. The epithet 'tenuicorticata' refers to the thin cortex ( $<6 \%$ of the radius).

Distribution and habitat. Usnea tenuicorticata was found to occur corticolous in Madeira (holotype), in Brazil, in rural areas, pastures, lower montane moist forests, Araucaria forests and Campos de altitude between 900 and 2100 m elevation; in Costa Rica (often on Alnus acuminata) in rural areas, pastures, roadsides, mountain tropical forests (on Quercus spp.) between 1500 and $2500 \mathrm{~m}$ elevation and in subparamo vegetation at 3200 m elevation; in El Salvador in Pine-Oak forests at $1500 \mathrm{~m}$ elevation, in Guatemala in an Alnus forest intermixed with pines at $2350 \mathrm{~m}$ elevation and in Mexico in a Quercus/Pinus forest at 2200 m elevation. One saxicolous specimen was found in Guatemala on a sandstone rock wall at $1450 \mathrm{~m}$ elevation. Morphological, chemical and genetical evidences show that this species also occurs in Colombia, in subparamo at 3400 m elevation 

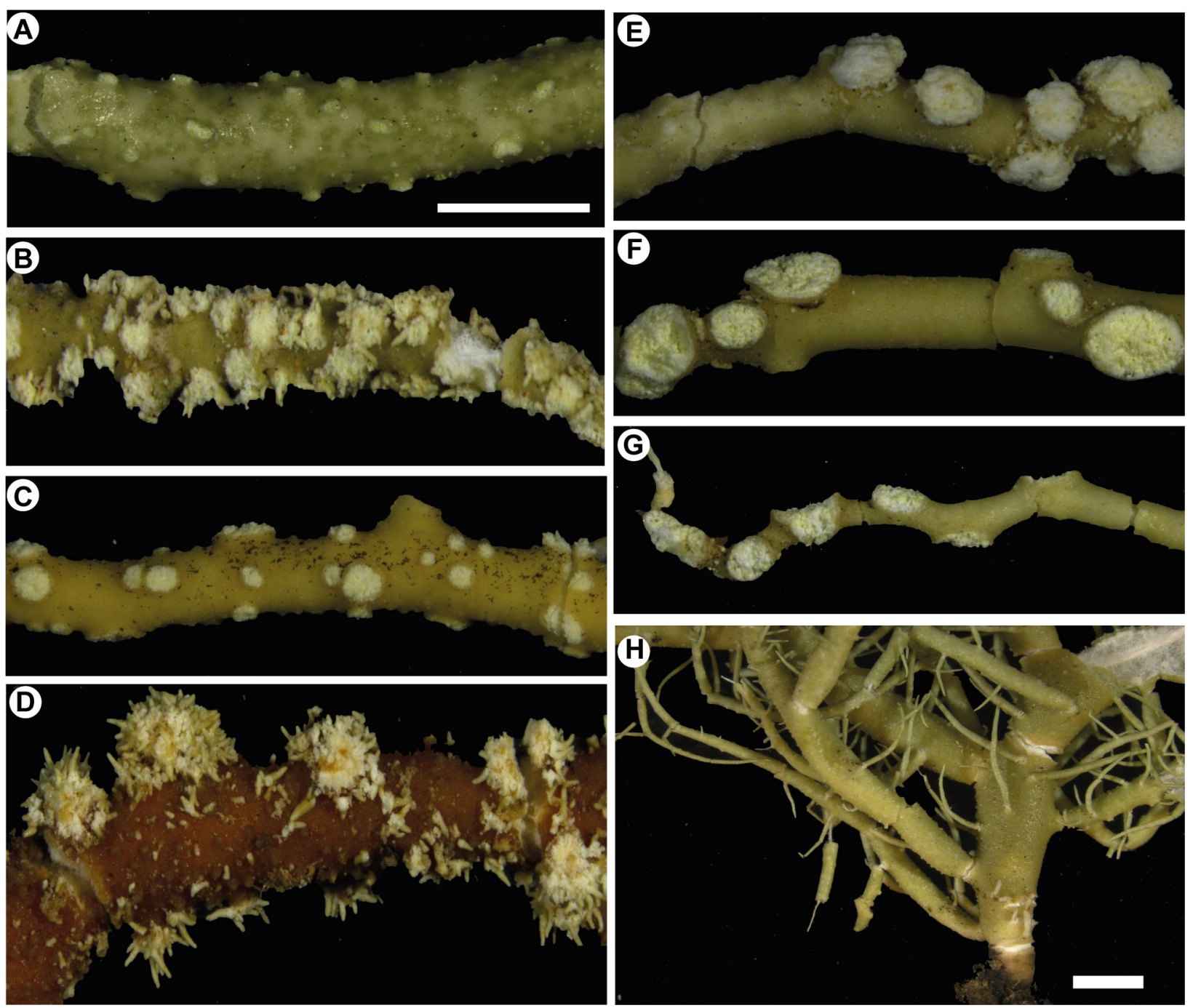

Figure 9. Usnea tenuicorticata. A - young minute soralia (Gerlach, Clerc \& Dal-Forno 2373, DNA 374); B - irregular soralia with isidiomorphs (Gerlach \& Clerc 2538, DNA 462); C - mature circular soralia, with a thin cortical rim (Truong 2014/190); D - strongly convex soralia covered with isidiomorphs (Kalb \& Plöbst 250578); E - typical and mature large and capitate soralia (Clerc 2015/55); F - plane to slightly concave large soralia (Clerc 2016/102); G - overmature, excavated soralia on terminal branches (Clerc 2016/102); H - fusiform main branch (Clerc 2015/628). Scales: $\mathrm{A}-\mathrm{G}=500 \mu \mathrm{m} ; \mathrm{H}=2 \mathrm{~mm}$.

(com. pers. B. Moncada \& R. Lücking 41067 [B (B 60 0200043), JBB].

Diagnostic notes. Inside the $U$. brasiliensis species group, the most important diagnostic character of $U$. tenuicorticata is the presence (mature thallus) of large ( $>1 / 2$ branch diameter) and conspicuous soralia of \pm circular outline remaining discrete (Fig. 9C), rarely aggregating. The second important diagnostic character is the thin cortex correlated with the large medulla resulting in a high ratio $\mathrm{M} / \mathrm{C}(\geq 7)$ (Fig. 4).

Variation. The size of soralia in $U$. tenuicorticata widely varies depending on the maturity of the thallus (Fig. 9A-G). Young, parasitized or badly developed thalli might have small punctiform soralia while typical thalli have large and conspicuous soralia. Overdeveloped soralia might become concave and \pm excavate (Fig. 9F-G) or inversely strongly convex (Fig. 9D-E) sometimes covered with isidiomorphs (Fig. 9D). Isidiomorphs might be almost absent to numerous, densely covering the terminal branches. The presence and morphology of papillae is very variable too, from few and indistinct to verrucous and conspicuous.

Discussion. Usnea tenuicorticata corresponds to lineages 2 and 4 (Gerlach et al. 2019) that merge together in this study (analysis of six more specimens) with high probabilities ( $\mathrm{PP}=0.98$, Fig. 1).

The large, discrete and rarely excavate soralia of circular shape readily separate $U$. tenuicorticata from all other species of the $U$. brasiliensis aggr. However, when soralia are badly developed, or young and immature, $U$. tenuicorticata might be difficult to tell apart from $U$. flabelliformis, the other species with a high ratio M/C. In this case, the main branch morphology with distinctly fan-shaped and \pm flattened segments in U. flabelliformis opposite to the more sausage-like and cylindrical segments in section is a good diagnostic character. The specimen 253BR appears to be interesting since it is nested inside the $U$. tenuicorticata lineage (Figs 1-2), but has a characteristic $U$. flabelliformis morphology with small 
and distinctly stipitate soralia aggregating together, as well as distinctly fan shaped and flattened main branches segments. We might have here a potential discrepancy between molecular and morphological data. Further studies outside the scope of this work are needed. Usnea brasiliensis $\mathrm{s}$.str. has a lower ratio $\mathrm{M} / \mathrm{C}(<7)$, smaller soralia that aggregates together forming consoralia. Because of the large variability in its soralia morphology, U. tenuicorticata might sometimes be difficult to separate from $U$. macaronesica, the other species of this group with large soralia. In this case the medulla is diagnostic: lax, one layered in U. macaronesica and dense, two layered in $U$. tenuicorticata. Moreover, barbatic acid is never present in U. tenuicorticata. Usnea glabrata, not treated in this study, is another species with constricted lateral branches, protocetraric acid in the medulla and large conspicuous soralia. It differs however from $U$. tenuicorticata by the strongly excavate soralia at maturity without cortical rim at all and without isidiomorphs. Moreover, branches of this species are smooth, without papillae (Clerc 2007).

Selected specimens analyzed. BRAZIL. Minas Gerais: Serra da Mantiqueira, Itamonte, Parque Nacional Itatiaia, Estrada das Prateleiras, $22^{\circ} 22^{\prime} 07^{\prime \prime} \mathrm{S}, 44^{\circ} 44^{\prime} 43^{\prime \prime} \mathrm{W}$, alt. $2050 \mathrm{~m}, 22$ Nov. 2017, P. Clerc, A. Gerlach \& M. Dal-Forno 17/129 (G, DNA 266). Paraná: Lapa, Reserva Particular do Patrimônio Natural Uru, 26 Oct. 2012, Ristow 2527 (G). Rio Grande do Sul: São Francisco de Paula, em direção a Cambará do Sul, beira de mato, 27 Juin 1985, Balbueno s.n. (ICN 71306). Santa Catarina: Urubici, Parque Nacional de São Joaquim, Santa Bárbara, estrada para o Morro do Baú, 28 $08^{\prime} 41^{\prime \prime} \mathrm{S}, 49^{\circ} 37^{\prime} 56^{\prime \prime} \mathrm{W}$, alt. $1443 \mathrm{~m}$, on branches of Araucaria angustifolia, A. Gerlach, P. Clerc \& S. Feuerstein 2373 (ICN, DNA 374). São Paulo: Campos do Jordão, Pico do Itapeva, on fallen Croton celtidifolius, alt. 1870 m, 28 Nov. 2017, A. Gerlach, P. Clerc, \& M. Dal-Forno 2552 (G, DNA 289). COSTA RICA. Province of San José: Pérez Zeledon Co. Cordillera de Talamanca, Parque Nacional Chirripó, zone anthopogène de paturâges et de cultures, branches au sol, 9 ${ }^{\circ} 27^{\prime} 51.4^{\prime \prime} \mathrm{N}, 83^{\circ} 34^{\prime} 53.6^{\prime \prime} \mathrm{W}$, alt. $1750 \mathrm{~m}, 13$ Sept. 2014, P. Clerc \& G. Loza 2015/628 (G). El SALVADOR. Department of Santa Ana: Metapán, Parque Nacional Montecristo, dans la forêt de Cupressus lusitanica, 14²3'37.9' $\mathrm{S}, 89^{\circ} 21^{\prime} 30.3^{\prime \prime} \mathrm{W}$, alt. 1843 m, 15 Jan. 2013, P. Clerc, C. Rojas \& E. Morales 2015/972 (G). GUATEMALA. Verapaz: kurz nach Salamá, Nordseitiger Weghang an stark verwitterten Sandsteinfelsen, alt. $1450 \mathrm{~m}$, 31 Jan.1979, K. Kalb \& G. Plöbst s.n. (G). MEXICO. Chiapas: etwa $25 \mathrm{~km}$ NW von Comitán de Dominguez. In einem schattigen, trockenen Eichen, Kiefern-Wald, alt. 2150 m, 25 Jan. 1979, K. Kalb \& G. Plöbst s.n. (G)

\section{The $U$. cornuta s.l. species group}

The artificial species group $U$. cornuta aggr. is defined by the absence of protocetraric acid and secondarily of psoromic and barbatic acids as main substances ( $U$. cornuta s.l. morphospecies in Gerlach et al. 2019). The main substances produced by species of this group are the $\beta$-orcinol depside: thamnolic acid, the orcinol depsidone: lobaric acid, the $\beta$-orcinol depsidones: constictic, lobaric, norstictic, stictic and salazinic acids, and the fatty acid caperatic in the medulla or in the soralia. Phylogenetic analysis revealed at least six distinct lineages (lineages 1 , $3,5,9,13,14$ and 15) associated with the aforementioned substances. A posteriori detailed morphological and anatomical analysis of each of these lineages revealed distinct morphological and anatomical characteristics for at least six of them. Lineages 1 and 13 are described here as new species, respectively $U$. stipitata and $U$. arianae. Lineages 3,5 and 9 are here hypothetically assigned respectively to $U$. trachyclada, U. cornuta and U. subpectinata. Lineage 14 appears to be complex and not supported by molecular analysis (Fig. 1). It needs more material and further studies to be resolved. Finally, lineage 15 that was not considered in Gerlach et al. (2019) corresponds to U. boomiana.

Usnea arianae P. Clerc, E. Caviró \& A. Gerlach, sp. nov. (Fig. 10A-H)

\section{MycoBank MB 836036}

Diagnosis: Differs from U. cornuta Körb. by its individual large, convex, efflorescent soralia covered with numerous short isidiomorphs, the lax medulla, a complex medullary chemistry (lobaric/ norstictic acids/fatty acid/) and its molecular phylogenetic position.

Type: Switzerland, Geneva, Commune de Russin, Vallon de 1'Allondon, Les Baillets, $46^{\circ} 12^{\prime} 18.3^{\prime \prime} \mathrm{N}, 5^{\circ} 59^{\prime} 50.8^{\prime \prime} \mathrm{E}$, alt. 380-390 m, August 2018, P. Clerc, A. Kissling \& E. Favre ( $\mathrm{G}$ - holotype, GenBank: MT339224). Chemistry: usnic and lobaric acids. $\% \mathrm{C} / \mathrm{M} / \mathrm{A}: 4 / 35 / 22 . \mathrm{A} / \mathrm{M}=0.6 ; \mathrm{M} / \mathrm{C}=8.7$.

Description ( $\mathrm{n}=32$ ). Thallus shrubby, short, $2-5(-6) \mathrm{cm}$ long, with anisotomic-dichotomous ramifications; basal part thinner than main branches, usually jet black on the first $\mathrm{mm}$, rarely concolorous with main branches, without distinct annular cracks; main branches $0.7-1.9 \mathrm{~mm}$ diameter, often strongly irregular in longitudinal section; segments often terete, sometimes flattened, distorted; lateral branches distinctly constricted at attachment points; terminal branches irregular; foveolae and transverse furrows present, rarely absent; pseudocyphellae and maculae absent; papillae (early stages of fibrils?) small, verrucous to indistinct, usually densely covering main branches or few to rarely absent; tubercles absent; fibrils slender, few to absent, irregularly distributed; fibercles numerous, punctiform to enlarged; soralia (Fig. 10A-G): a) minute, $\geq 1 / 2$ branch diameter when mature, $100-350 \mu \mathrm{m}$, b) \pm circular to irregularly shaped, c) even with the cortex, rarely slightly stipitate, d) typically convex-efflorescent when isidiomorphs present or almost plane when isidiomorphs are shed, e) thin but distinct cortical rim, visible only when isidiomorphs are shed, f) sparse to moderately dense $\left.\left(4-9 / 0.25 \mathrm{~mm}^{2}\right), \mathrm{g}\right)$ usually well delimited, sometimes aggregating but rarely fusing together, rarely densely covering the small terminal branches that are twisted when heavily sorediate (Fig. 10C), h) mostly located on terminal branches; isidiomorphs short and numerous, often densely covering soralia and giving the efflorescent aspect; isidiofibrils absent to rarely present, never numerous; apothecia rare, up to $7 \mathrm{~mm}$ large, terminal, with corticated margin; ascospores absent; cortex thin to moderately thin (Table 1), shiny, of the ceratina-type; medulla lax, thick (Table 1); axis thin (Table 1). CMA of the cornuta-type (Figs 4, 10H). 
Chemistry. Usnea arianae has the most complex and variable chemistry of the group with four chemotypes. Lobaric acid is present in $69 \%$ of the specimens analyzed, mostly alone, rarely with norstictic acid or two unknown fatty acids. It is present in most of the European and Macaronesian specimens studied. In the Southern Hemisphere, it is present in Ecuador, but absent in Brazil so far. Norstictic acid is present in $22 \%$ of the specimens analyzed in Europe and in Brazil. Two unknown fatty acids with the following $\mathrm{Rf}$ (A/B/C) 4/5/5 (FA1) and 4-5/6/5-6 (FA2) are present in $28 \%$ of the specimens studied, in Europe, Macaronesia and Brazil.

Chemotypes: 1) lobaric acid, $\pm \mathrm{FA} 1, \pm \mathrm{FA} 2(\mathrm{n}=18)$; medulla $\mathrm{K}-, \mathrm{P}-; 2) \pm \mathrm{FA} 1, \pm \mathrm{FA} 2(\mathrm{n}=7)$ : medulla $\mathrm{K}-$, $\mathrm{P}-; 3)$ norstictic, $\pm \mathrm{FA} 1, \pm \mathrm{FA} 2(\mathrm{n}=4)$; medulla $\mathrm{K}+$ reddish; 4) norstictic and lobaric acids $(\mathrm{n}=3)$; medulla $\mathrm{K}+$ reddish. Soralia always $\mathrm{K}-$, $\mathrm{P}-$ (Fig. 3).

Etymology. This taxon is named in honour of Alice's dear sister Ariane, who passed away at the time when this species was studied and described.
Distribution and habitat. Usnea arianae was first collected in 1969 in the Algarve (Portugal) on Quercus suber. In Europe, this species was further collected in Brittany (France) in wetlands on Betula pendula, in Atlantic North Western Spain on Acacia dealbata, and most recently in the Dordogne (France), southern Corsica (France), Iberian Peninsula (Caviró 2015) and inland in Switzerland (Clerc \& Kissling 2019) within riparian vegetation types. It is further known from Macaronesia (Tenerife and La Gomera) occurring in rural areas, in Fayal Brezal communities or in the Laurisylve between $900 \mathrm{~m}$ and $1450 \mathrm{~m}$ elevation. This suggests a South Western Mediterranean Atlantic type of distribution with a probable recent extension inland. In the Southern Hemisphere, it is known from Brazil (Araucaria forest, Campo de altitude) between $1300 \mathrm{~m}$ and $2450 \mathrm{~m}$ elevation and from Ecuador on Podocarpus sp. at $1030 \mathrm{~m}$ elevation.

Diagnostic characters. Inside the Usnea cornuta aggr., $U$. arianae is a small species $(2-5 \mathrm{~cm})$ characterized by the convex efflorescent soralia covered with isidiomorphs (Fig. 10E-F) rarely with isidiofibrils, the short jet black
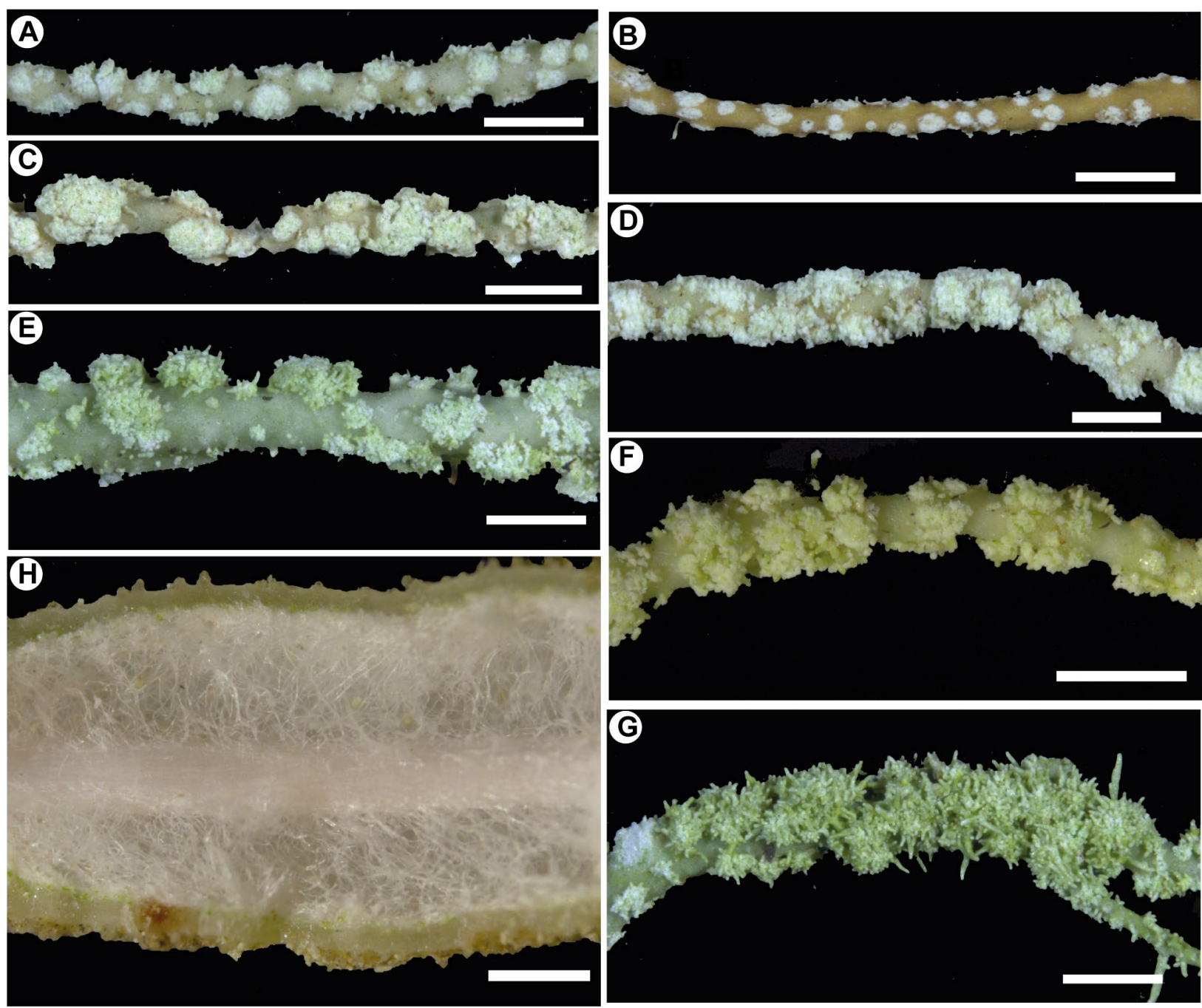

Figure 10. Usnea arianae. A, B - young and well delimited soralia (A: Aptroot 75514, DNA 232; B: Clerc 2009/179); C - twisted terminal branches densely covered with aggregating soralia (Gerlach \& Penati 2016/P1, DNA 192); D - \pm convex efflorescent soralia (Aptroot 75514, DNA 232); E, F - mature, convex efflorescent soralia, with small isidiomorphs (E: Aptroot 75514, DNA 232; F: Aptroot 75517, DNA 231); G - aggregating soralia richly covered with isidiomoprhs (Clerc \& Ohmura G00599921); H - transversal section of main branch, CMA of cornuta-type CMA, thin axis and lax medulla (Clerc, Kissling \& Favre s.n., holotype). Scales: A-H $=500 \mu \mathrm{m}$. 
pigmentation of the basal part, the presence of cortical furrows, the lax medulla (Fig. $10 \mathrm{H}$ ) containing lobaric acid (in $69 \%$ of the analyzed specimens) and/or FA1/ FA2 (28\%) (Table 2).

Variation. The morphology of soralia might vary a lot depending whether isidiomorphs are shed or not (Fig. 10A-G). When isidiomorphs are present, soralia are strongly convex-efflorescent, covered with isidiomorphs (Fig. 10E-G). When isidiomorphs are shed and absent (or few), soralia are \pm flat, level with cortex, with a thin but distinct cortical rim (Fig. A-D). Papillae (or early stages of fibrils) usually cover densely the main branches, but sometimes they might be few and indistinct. Although cortical furrows seem to be always present, their frequency is quite variable from very few to numerous.

Discussion. Usnea arianae corresponds to lineage 13 in Gerlach et al. (2019) and Figure 1. For differences with the other taxa of the $U$. cornuta aggr., see under these taxa. Usnea flammea also with lobaric acid in the medulla (Clerc 2006), differs from $U$. arianae mainly by the mat cortex in section, the pale and annulated basal part, the branches that are not or only slightly constricted at attachment point and the presence of the stictic ac. aggr. in the medulla (Clerc 2006). Usnea peruviana (W - holotype!), an Andean species of the U. cornuta aggr., also has traces of lobaric acid in the medulla. It differs however by the soralia, that are distinctly stipitate and have a thick cortical rim, and that are present not only on terminal, but on main branches as well. Moreover, all specimens of the holotype sheet of $U$. peruviana show a pale yellow unknown substance (Rfs: A/5-6, B/2, C/5) UV green after charring on the chromatogram.

Lobaric acid, rarely absent in Europe and Macaronesia, was not found (at least not detected with TLC) in Brazilian specimens. However, these specimens cluster well with the European specimens (Figs 1-2) and show the typical morphology of $U$. arianae.

Selected specimens analyzed. BRAZIL. Minas Gerais: Gonçalves, próximo ao Chalé Três Irmãs, $22^{\circ} 43^{\prime} 56.75^{\prime \prime} \mathrm{S}$, $45^{\circ} 52^{\prime} 46.67^{\prime \prime} \mathrm{W}$, alt. $1400 \mathrm{~m}$, on fences, 2016, A. Gerlach \& R. Penati 2016/P1-8 (ICN, DNA 192). Paraná: Palmas, Refugio de Vida Silvestre dos campos de Palmas, 13.12.2013, M. E. Engels \& E. Lozano s.n. (G). Santa Catarina: Urubici, Parque Nacional de São Joaquim, Santa Bárbara, vicinity of the research station, on small branches of a shrub, $28^{\circ} 08^{\prime} 31^{\prime \prime} \mathrm{S}$, $49^{\circ} 38^{\prime} 7^{\prime \prime} \mathrm{W}$, alt. $1350 \mathrm{~m}$, P. Clerc, A. Gerlach \& S. Feuerstein 17/112 (G, dupl. ICN 195557, DNA 297). ECUADOR. ZamoraChinchipe, $04^{\circ} 06^{\prime} 42^{\prime \prime} \mathrm{S}, 78^{\circ} 7^{\prime} 49^{\prime \prime} \mathrm{W}$, alt. $1030 \mathrm{~m}, 20$ Jan. 2009, J. R. Grant et al. 09-4564 (G). FRANCE. Bretagne: Finistère, Reserve Naturelle du Venec, sur Salix sp., Dec. 2007, B. Lorella s.n. (G). PORTUGAL. Parque Natural da Peneda-Gerês, sobre Betula pendula, alt. 957 m, Sept. 2014, R. Arroyo, E. Seriñá \& E. Araujo s.n. (MACB, DNA EA4612). SPAIN. Ourense: Parque Natural Baixa Limia-Serra do Xurées, Entrimo, Mirador de San Rosendo do Pedreirinho, sobre Pinus pinaster, alt. 740 m, 2013, R. Arroyo et al. EA329(5) (MACB, DNA EA4488). SWITZERLAND. Geneva, Commune of Russin, Les Baillets, Allondon valley, on Quercus robur, Carpinus betulus, Prunus spinosa, Crataegus sp., 46 $12^{\prime} 18.3^{\prime \prime} \mathrm{N}, 5^{\circ} 59^{\prime} 50.8^{\prime \prime} \mathrm{E}, \sim 380 \mathrm{~m}$, 18.07.2019, Clerc \& Ohmura s.n. (G00599921).
Usnea boomiana P. Clerc, Candollea 70: 167. 2015.

(Fig. 7B-F)

\section{MycoBank MB 807125}

Type: Spain, Canary Islands, El Hierro: SSE of Frontera, near mountain top, along trail in 'fayal brezal' forest, $27^{\circ} 44.15^{\prime} \mathrm{N}$, $17^{\circ} 59.50^{\prime} \mathrm{W}$, alt. $1300 \mathrm{~m}$, on Erica sp., 31 Mars 2009, P. van den Boom \& B. van den Boom 42838 (G! - holotype). Chemistry: usnic and caperatic acids. $\% \mathrm{C} / \mathrm{M} / \mathrm{A}: 7 / 33 / 19$. $\mathrm{A} / \mathrm{M}=0.6$. $\mathrm{M} / \mathrm{C}=4.7$.

Description. Detailed description and illustrations are available in van den Boom et al. (2015).

Chemistry. Chemotypes: 1$)$ caperatic acid $(\mathrm{n}=11)$, medulla $\mathrm{K}-$, $\mathrm{P}-$, soralia $\mathrm{K}-, \mathrm{P}-$; 2) caperatic and norstictic acids (weak) $(\mathrm{n}=3)$, medulla $\mathrm{K}-, \mathrm{P}-$, soralia $\mathrm{K}+$ pale yellow, $\mathrm{P}+$ yellowish (Fig. 3).

Distribution and habitat. So far known from the Canary Islands on La Gomera (van den Boom et al. 2015). New for South America in Brazil where it was found in rural areas, lower montane moist forests, Araucaria forest and Campos de altitude between 900 and $2100 \mathrm{~m}$, and for Central America in Costa Rica where it was found mainly in rural areas between $1600 \mathrm{~m}$ and $1900 \mathrm{~m}$. One saxicolous specimen was found in Brazil in Campo de altitude on cemetery wall stones.

Diagnostic characters. In the Usnea cornuta aggr., $U$. boomiana is characterized by their large, flat (Fig. 7F) to distinctly convex, capitate and efflorescent soralia (Fig. 7C-E) and the constant presence of caperatic acid (van den Boom et al. 2015).

Variation. In Brazilian and Central American specimens, at the end of thinner branches and when isidiomorphs are shed, soralia enlarge and become \pm concave and slightly excavate (Fig. 7F). Norstictic acid might be present as well in Macaronesian specimens (not mentioned in Boom et al. 2015).

Discussion. Usnea boomiana corresponds to lineage 15 (Fig. 1). The Brazilian specimens differ from the Macaronesian species by the higher frequency of overmature flat to \pm excavate soralia without isidiomorphs (Fig. 7F). Such soralia are indeed rare in the Macaronesian material. However typical capitate and efflorescent mature soralia with isidiomorphs (Fig. 7C-D) are always present in the Brazilian specimens. Beside caperatic acid, norstictic acid is present in Macaronesian material as well (not mentioned by Boom et al. 2015). For these reasons, and despite the fact that we do not have any sequence from specimens collected in Macaronesia, we decided not to describe a new species, but to attribute lineage 15 to U. boomiana.

Among the species of the Usnea cornuta aggr. Usnea arianae is the only other species with a $\mathrm{K}-, \mathrm{P}-$ medulla. Both species are morphologically quite similar. However, U. boomiana has much thicker cortex and a thinner medulla and consequently a much lower $\mathrm{M} / \mathrm{C}(<5$ versus 4.5-6.6-8.7 in U. arianae). Moreover, both species differ by their chemistry with caperatic acid being diagnostic 
for U. boomiana. Usnea subaranea is a tropical Andean species with constricted lateral branches and large soralia that can sometimes have a $\mathrm{K}-$, $\mathrm{P}-$ medulla as well. However, this species never produces caperatic acid and has a typical arachnoid medulla (Truong \& Clerc 2016). Usnea nipparensis, an eastern Asiatic species, is another taxon with caperatic acid (Ohmura 2001). However, the holotype (TNS!) has a very different CMA values (9.5/16.5/48), A/M ratio (5) and $\mathrm{M} / \mathrm{C}$ ratio (1.7). Moreover the medulla is compact (dense to lax in $U$. boomiana) and the lateral branches are only slightly constricted. Finally, $U$. nipparensis is not phylogenetically related to U. boomiana (Fig. 1). For differences with other species with large soralia, see van den Boom et al. (2015).

Selected specimens analyzed. BRAZIL. Minas Gerais: Itamonte, Parque Nacional do Itatiaia, estrada das prateleiras, $22^{\circ} 21^{\prime} 54^{\prime \prime} \mathrm{S}, 44^{\circ} 43^{\prime} 36^{\prime \prime} \mathrm{W}$, mata nebular, Nov. 2017, A. Gerlach, P. Clerc \& Dal-Forno 2455 (ICN, DNA 459). Santa Catarina: Urubici, Parque Nacional de São Joaquim, Santa Bárbara, estrada para Morro do Baú, on branche of Araucaria angustifolia, $28^{\circ} 08^{\prime} 41^{\prime \prime} \mathrm{S}, 49^{\circ} 37^{\prime} 56^{\prime \prime} \mathrm{W}, 19$ Nov. 2017, A. Gerlach, P. Clerc \& S. Feuerstein 2373 (ICN). São Paulo: Campos do Jordão, estrada para o Pico do Itapeva, em frente a casa 7800 , matinha nebular, $22^{\circ} 45^{\prime} 58^{\prime \prime} \mathrm{S}, 45^{\circ} 32^{\prime} 27^{\prime \prime} \mathrm{W}, 28$ Nov. 2017 ,
A. Gerlach, P. Clerc \& M. Dal-Forno 2541 (G, DNA 283). COSTA RICA. Province of Alajuela: Alajuela Co., Poasito, $10^{\circ} 9^{\prime} 25^{\prime \prime} \mathrm{N}, 84^{\circ} 11^{\prime} 46^{\prime \prime} \mathrm{W}$, alt. $1917 \mathrm{~m}$, sur le tronc d'un décidu, dans le jardin du restaurant, 22 Jan. 2013, P. Clerc \& C. Rojas 2015/248 (G).

Usnea cornuta Körb., Parerga lichenologica: 2. 1865.

(Fig. 11A-G)

\section{MycoBank MB 408356}

Type: Germany. ad saxa arenaria «des Regensteins» prope Blankenburg Hercyniae, Hampe s.n.; Koerber, Lich. Sel. Germ. $\mathrm{n}^{\circ} 181$ (G! - isolectotype). Chemistry (lectotype): usnic, salazinic, constictic, protocetraric acids. $\% \mathrm{C} / \mathrm{M} / \mathrm{A}$ (lectotype): 4/35.5/21 (\%C/M/A and chemistry by Clerc 1987b).

Description $(\mathrm{n}=33)$. Thallus shrubby, 2.5-7(-9) $\mathrm{cm}$ long; with anisotomic-dichotomous ramifications; basal part concolorous with branches, sometimes blackish near the holdfast; main branches $0.9-1.6 \mathrm{~mm}$ diameter, slightly irregular in longitudinal section, terete in transversal section, \pm distinctly segmented; segments cylindrical to often \pm swollen; lateral branches distinctly constricted at attachment points (Fig. 11A); terminal branches \pm thick, with small lateral branches splitting at right angle; foveolae
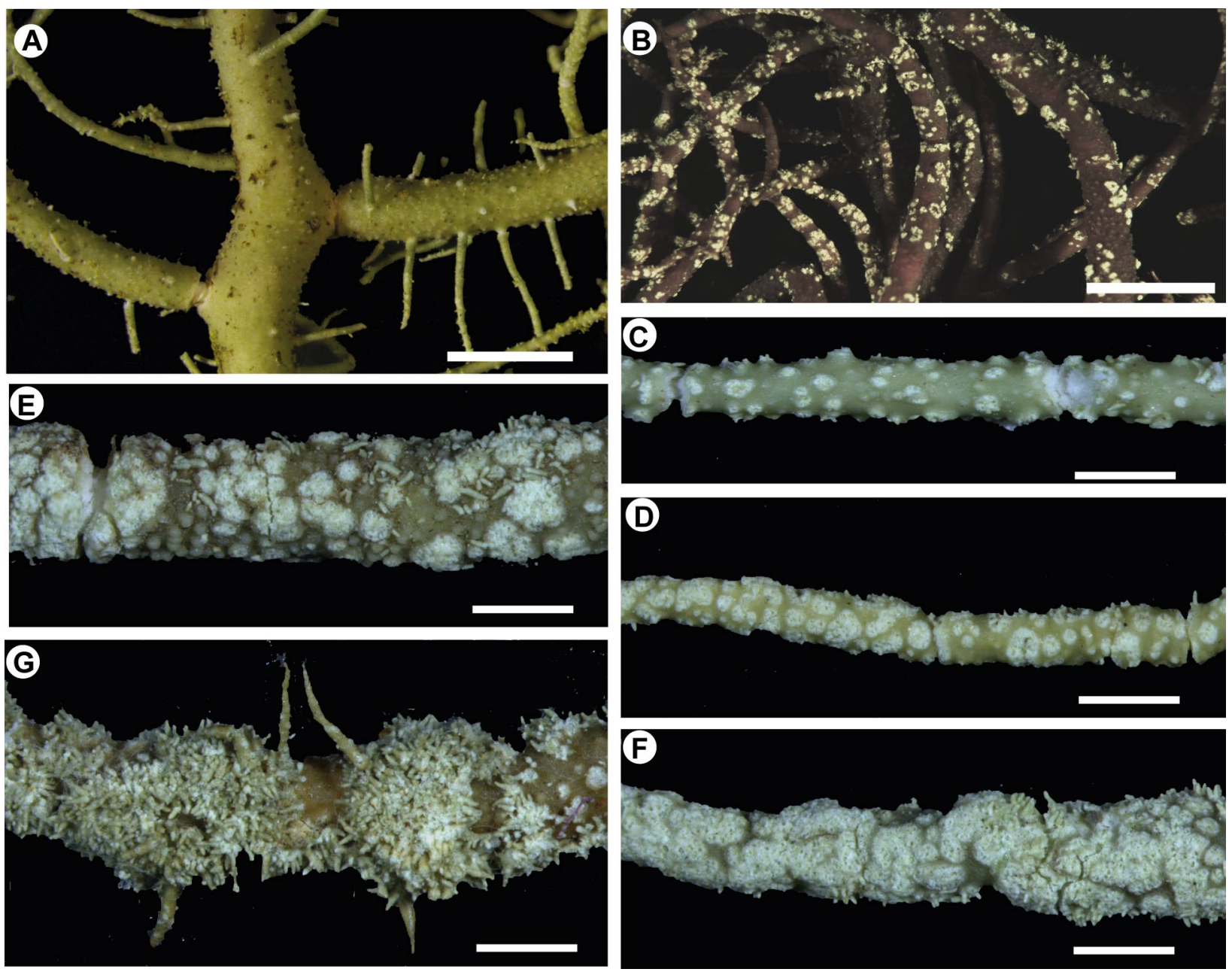

Figure 11. Usnea cornuta. A - lateral branches constricted at attachment point (DNA 198); B - terminal branches densely covered with consoralia (Grundlehner s.n.); C - minute, young and isolated soralia (Gerlach \& Clerc 2552, DNA 287); D - numerous, mature soralia fusing into consoralia towards the end of the branch (Aptroot 75462, DNA 233); E, F - mature consoralia (E: Gerlach \& Penati 2016/ P47, DNA 124; F: Gerlach \& Penati 2016/ P47, DNA 124); G - strongly convex and overdeveloped consoralia covered with isidiomorphs (Canestraro \& Lozano 487). Scales: $\mathrm{A}-\mathrm{B}=2 \mathrm{~mm} ; \mathrm{C}-\mathrm{G}=500 \mu \mathrm{m}$. 
and transverse furrows sometimes present, not abundant; maculae and pseudocyphellae absent; papillae few, verrucous, sparsely distributed to numerous \pm densely covering the branches; tubercles absent; fibrils short and \pm spinulous to slender, never densely arranged but scattered and unevenly distributed on the whole thallus, often giving a spinulous aspect to the terminal part of the thallus; fibercles scattered on whole thallus; soralia (Fig 11B-G): a) minute, 50-150 $\mu \mathrm{m}$, when numerous fusing together to form larger consoralia $(150-200 \mu \mathrm{m})$ sometimes completely covering terminal branches, b) irregular, c) \pm even with cortex, d) plane, e) without a well delimited cortical rim, f) numerous on mature specimens, $10-17 / \mathrm{mm}^{2}, \mathrm{~g}$ ) forming consoralia, h) mainly located on terminal branches; isidiomorphs few to numerous, sometimes densely covering the branches; isidiofibrils absent to numerous, sometimes densely covering the branches; apothecia sometimes present, terminal, $\sim 2 \mathrm{~mm}$ diameter; ascospores $7-8.5(-10) \times 5-6 \mu \mathrm{m}(\mathrm{n}=10)$; pycnidia not seen; cortex thin to moderately thick (Table 1), shiny, of the ceratina-type; medulla moderately thick to thick (Table 1), thin to dense; axis thin (Table 1) CMA of the cornuta-type (Fig 4).

Chemistry. Chemotypes: 1) salazinic acid, \pm constictic acid, \pm (trace) protocetraric acid, \pm unidentified fatty acids Rf Classes A/B/C: 4/5/5 and 5/5/5 $(\mathrm{n}=40)$, medulla $\mathrm{K}+$ yellow $\rightarrow$ red; 2) Constictic acid alone $(n=5)$, medulla $\mathrm{K}+$ yellow; 3) salazinic, norstictic acids, \pm stictic acid (trace), \pm fatty acid Rf classes 4/4-5/5 (n=3), medulla K+ yellow $\rightarrow$ red; 4) stictic acid $(\mathrm{n}=2)$, medulla $\mathrm{K}+$ yellow. Soralia K-, P- (Fig. 3).

Distribution and habitat. In Europe, Usnea cornuta belongs to the 'ominvage euoeanische Element" (Degelius 1935), i.e. species ranging from SW Norway to Portugal (Clerc 1987a, b, 2011; Caviró 2015), mainly close to the Atlantic coast although it may occur inland (see for instance Clerc 1998). It is a frequent species in the Macaronesian islands (Clerc 2006). In the Northern Hemisphere, U. cornuta s.str. occurs in Japan (as U. confusa) and in Taiwan (Ohmura 2001, 2012; Ohmura \& Clerc 2019). Its occurrence in North America is probable, but needs confirmation. According to Truong (2012), it corresponds to a very common species at a wide altitudinal range in the Neotropics. In South America, Usnea cornuta s.str. seems to occur secondarily on rocks in Argentina (Rodriguez et al. 2011). In Brazil, where it is mentioned for the first time (see however the discussion on $U$. jelskii below), $U$. cornuta s.str. seems to have a wide ecological range growing mainly corticolous and lignicolous on fences, rarely saxicolous, from sea level in rural areas to $1800 \mathrm{~m}$ elevation in mountainous areas in the Atlantic forest (Araucaria forest, Campo do altitude).

Diagnostic notes. Usnea cornuta is characterized by the short shrubby thallus, the lateral branches that are distinctly constricted at attachment points, the small punctiform soralia that are even with the cortex, often fusing into consoralia on terminal branches (Fig. 11D-F) with axils nearly $90^{\circ}$ (Clerc 1987b, Fig. 24) (Fig. 11A), a CMA, a CMA of the cornuta-type, a thin to moderately thick [5.6-7-8.4] shiny cortex and a lax to dense medulla containing salazinic acid as main secondary metabolite.

Variation. Branch segments can vary from slightly to distinctly swollen. The same applies for the constriction of lateral branches that might vary from slightly to distinctly constricted. Thalli exposed to strong insolation might produce numerous isidiomorphs and isidiofibrils. Specimens of this lineage show a quite variable secondary chemistry with four chemotypes that cluster together in the phylogenetic analysis.

Discussion. Usnea cornuta corresponds to lineage 5 in Gerlach et al. (2019) and Figure 1.

The soralia morphology and the presence of salazinic acid as main secondary metabolite tell us that the bulk of lineage 5 (Fig. 1) corresponds to Usnea cornuta s.str. Further studies with more material collected worldwide are needed to understand the genetic and chemical variability inside this lineage.

Mature and well developed specimens of Usnea arianae differ from $U$. cornuta by the large and convex efflorescent soralia covered with isidiomorphs, as well as the presence of lobaric acid (although not in Brazil) or norstictic acid and/or other fatty acids (Table 2). Salazinic acid has not been found so far in $U$. arianae. Young or badly developed specimens of $U$. arianae are difficult to separate from $U$. cornuta without TLC investigation. For differences with other species of the $U$. cornuta aggr., see below under these species.

Usnea dasaea differs mainly by the densely arranged spinulose fibrils on the branches and the presence of galbinic acid (Clerc \& Herrera-Campos 1997; Clerc 2004). Usnea perhispidella J. Steiner differs from U. cornuta by the non-inflated branches, covered by isidiofibrils and the thinner and compact medulla $(\mathrm{A} / \mathrm{M}$ ratio $>2)$ (Truong et al. 2013b) (see under U. subpectinata for more details). The status of $U$. jelskii described from Chile and synonymized under $U$. cornuta by Clerc (2004) needs to be reevaluated under the actual knowledge of the group. Usnea jelskii was mentioned in Rio de Janeiro by Rizzini (1952, 1956).

Selected specimens analyzed. ARGENTINA. Tucumán: El Infernillho, Km 519, alt. 1750 m, on rocks, 1989, S. Grundlehner 60.28.3 (G). BRAZIL. Minas Gerais: Gonçalves, Pedra Chanfrada, 2016, A. Gerlach \& R. Penati 2016/P63 (ICN). Paraná:

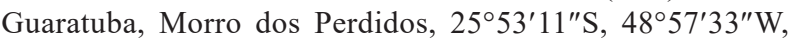
alt. 1300 m, A. Gerlach, E. Gumboski \& S. Eliasaro 1012b (ICN). Rio Grande do Sul: Esmeralda, Estação Ecológica de Aracuri, 1984, M. Fleig 2455 (ICN). Santa Catarina: Alfredo Wagner, Reserva Particular do Patrimônio Natural Rio das Furnas, $27^{\circ} 40^{\prime} 28.3^{\prime \prime} \mathrm{S}, 49^{\circ} 10^{\prime} 37.9^{\prime \prime} \mathrm{W}$, alt. $900 \mathrm{~m}, 2014$, A. Gerlach \& Giovanka 1272 (ICN). EL SALVADOR . Department of Santa Ana, Metapán, Parque Nacional Montecristo, $14^{\circ} 24^{\prime} 9^{\prime \prime} \mathrm{N}$, 89²1'36"W, alt. 1950 m, 2013, P. Clerc et al. 2015/1077 (G). FRANCE. Bretagne: Finistère, Reserve Naturelle du Venec, on Salix sp., 2007, B. Lorella s.n. (G, DNA 42). PORTUGAL. Ilhas Madeira, Porto Santo, 335' $5^{\prime} 8^{\prime \prime} \mathrm{N}, 16^{\circ} 18^{\prime} 44^{\prime \prime} \mathrm{W}, 2016$, A. Gerlach et al. 1577 (ICN, DNA 4). SPAIN. Anaga, i kmm E 
of Casa Forestal, $28^{\circ} 32^{\prime} 25^{\prime \prime} \mathrm{N}, 16^{\circ} 13^{\prime} 35^{\prime \prime} \mathrm{W}, \sim 850 \mathrm{~m}$., on Erica arborea, 2017, A. Aptroot 75462 (G, DNA 233).

Usnea stipitata A. Gerlach \& P. Clerc, sp. nov.

(Fig. 12A-E)

MycoBank MB 836037

Diagnosis: Differs from U. cornuta Körb. by the stipitate soralia, a thinner cortex and a larger medulla resulting in relatively low $\mathrm{A} / \mathrm{M}(0.4-0.5-0.6)$ and high $\mathrm{M} / \mathrm{C}(5-7-9)$ ratio values and by its phylogenetic position.

Type: Brazil, Santa Catarina, Alfredo Wagner, Reserva Particular do Patrimônio Natural Rio das Furnas, $27^{\circ} 40^{\prime} 28.3^{\prime \prime} \mathrm{S}$, $49^{\circ} 10^{\prime} 37.9^{\prime \prime} \mathrm{W}, \sim 900 \mathrm{~m}$, corticolous on Araucaria angustifolia, 14.v.2016, A. Gerlach et al. 2016/P39 (ICN - holotype, GenBank: MF669821). Chemistry: usnic and constictic acids. $\% \mathrm{C} / \mathrm{M} / \mathrm{A}: 5.5 / 37 / 14 . \mathrm{A} / \mathrm{M}=0.4 . \mathrm{M} / \mathrm{C}=6.7$.

Lineage 1 in Gerlach et al. (2019).

Description $(\mathrm{n}=42)$. Thallus shrubby to subpendulous when optimally developed, (3-) 6-9-12 (-19) cm; \pm stiff and rough with anisotomic-dichotomous ramifications; basal part short, up to $2 \mathrm{~mm}$ long, fusiform, paler than or concolorous to the branches, often with a faint reddish brownish tinge near holdfast, rarely blackened at the very base, sometimes with annular cracks; main branches (1-2.7) mm diameter, irregular in longitudinal section (especially close to the basal part), distinctly segmented with annular cracks (rarely with medullar extrusion) and cortex regeneration; segments irregular in shape, \pm swollen, terete to slightly flattened in transversal section; lateral branches distinctly constricted at attachment point; terminal branches \pm thick, with small lateral branches diverging at right angle; transverse furrows often present on main branches at end of the segments (Fig. 12E), foveolae often present; maculae absent; pseudocyphellae absent; papillae absent; tubercles (or initial stages of fibrils) almost absent to numerous, low verrucose $(70 \times 70 \mu \mathrm{m})$, usually densely covering the branches and then giving to the thallus a rough consistence; fibrils few and scattered to numerous and almost fish-bone like, slender, 2-3 mm long; fibercles few, scattered; soralia (Fig. 12B-D): a) punctiform, $\leq 1 / 2$ branch diameter, 50-120 (150) $\mu \mathrm{m}$ large, b) \pm circular shaped (top view), c) distinctly stipitate (side view), d) plane to capitate, e) with usually thin cortical rim, f) sparse to dense $\left.\left(4-12 / 0.25 \mathrm{~mm}^{2}\right), \mathrm{g}\right)$ rarely aggregating, never forming consoralia, h) located mainly on secondary and terminal branches; isidiomorphs short, almost absent to numerous,; isidiofibrils absent to few, rarely numerous on apices; apothecia and pycnidia not seen; cortex shiny, thin to moderately thin (Table 1), intermediate between ceratina and merrillii-types; medulla thick (Table 1), lax to dense, distinctly two-layered (Fig. 12A); axis thin (Table 1). CMA intermediate between the tenuicorticata and the cornuta-type (Figs 4, 12A).

Chemistry. Constictic, \pm salazinic acids, \pm unidentified fatty acid, \pm protocetraric acid (trace), \pm unknown spot brownish (Rf classes A/B/C: 1-2/2/1-2), \pm unknown yellow spot (Rf class $\mathrm{A} / \mathrm{B} / \mathrm{C}: 2 / 1-2 / ?), \pm$ unknown terpenoids $(\mathrm{n}=42)$; medulla $\mathrm{K}+$ yellow-reddish, $\mathrm{P}+$ yellow $\rightarrow$ yellowish-orange. Soralia always $\mathrm{K}-$, $\mathrm{P}-$ (Fig. 3).
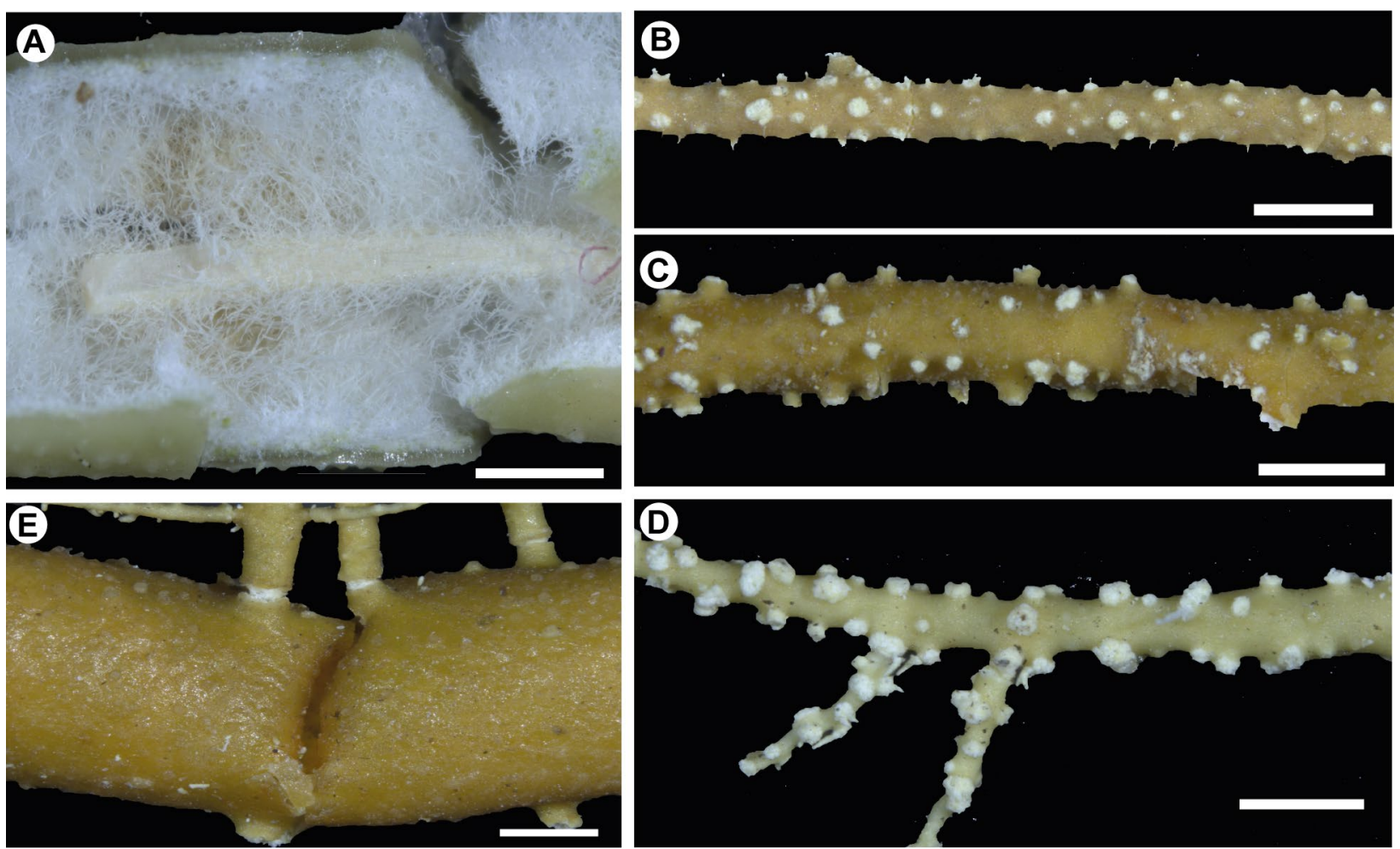

Figure 12. Usnea stipitata. A - transversal section of main branch showing large and lax medulla and thin cortex (Gerlach 2016/ P39, DNA 24); B - discrete, punctiform, \pm stipitate young soralia (Gerlach 1169b); C - mature stipitate, \pm circular and well delimited soralia (Gerlach \& Akkerman 1445); D - overmature stipitate and capitate soralia (Fazolino s.n.); E - transversal furrow on main branch (Gerlach \& Akkerman 1445). Scales: A-E $=500 \mu \mathrm{m}$. 
Etymology. The epithet refers to the shape of the soralia (side view) which mostly develop on top of fibercles and then are typically stipitate.

Distribution and habitat. In Brazil, it was found in the Southern and Southeastern parts in rural areas, lower montane moist forests and Araucaria forests between 900 and 2000 m, corticolous on bark of Araucaria angustifolia or of exotic species of Pinus, and lignicolous on fences. The two specimens from Costa Rica were found in rural areas between 1500 and $1900 \mathrm{~m}$, on deciduous trees.

Diagnostic notes. The distinguishing features of Usnea stipitata are the subpendulous growth, the pale to brownish basal part, the discrete, punctiform, never enlarging, stipitate and \pm circular shaped (top view) soralia (Fig. 12B-D) developing on top of fibercles, the low $\mathrm{A} / \mathrm{M}$ [0.4-0.5-0.6] and the high $\mathrm{M} / \mathrm{C}$ ratio [5-7-9] (Fig. 12A), the distinctly constricted lateral branches at ramification points, the strongly irregular main branches often with transverse furrows (Fig. 12E) and/or foveoles, as well as the constant presence of constictic acid.

Variation. Some specimens are robust and stiff while others are thinner and soft. The frequency (from few to numerous) and size (almost indistinct to large and tubercle-like) of fibercles display a spectacular variation. The presence of fibrils is very variable too, from almost absent to numerous and \pm fish bone like. Foveolae and transverse furrows vary from absent to frequent and conspicuous are the most variable features of this species.

Taxonomic notes. Among the species of the U. cornuta aggr., Usnea stipitata differs from U. cornuta s.str. by a more subpendulous growth (when optimally developed), the less irregular main branches, the discrete and distinctly stipitate soralia, a thinner cortex and a larger medulla (33.9-36.4-38.9; U. cornuta: 27.9-31.2-34.5) and the presence of constictic acid as a constant medullary substance. However U. cornuta s.str. has a chemotype with constictic acid as well. Juvenile or badly developed specimens of the $U$. cornuta aggr. with constictic acid alone or with salazinic and constictic acids are thus impossible to identify without genetic barcoding. Usnea arianae differs from $U$. stipitata by the large, convex, efflorescent soralia and by its distinct chemistry. For differences with the other species of the $U$. cornuta aggr., see under these species below. Usnea ceratina has similar stipitate soralia. However, this species has a strawberry pigmented medulla, unconstricted lateral branches and diffractaic/ barbatic acid in the medulla.

Selected specimens analyzed. BRAZIL. Minas Gerais: Gonçalves, caminho para a pousada Pedra da Lua, alt. 1580 m, 2016, A. Gerlach \& R. Penati 2016/P21 (ICN). Paraná: Adrianópolis, Parque Estadual Lauraceas, 21 Feb. 2013, M. Engels et al. 638c (G). Rio Grande do Sul: Cambará do Sul, Parque Nacional dos Aparados da Serra, Cânion Itaimbezinho, 2014, A. Gerlach \& M. Akkerman 1418 (ICN). Santa Catarina: Alfredo Wagner, Reserva Particular do Patrimônio Natural Rio das Furnas, 2016, A. Gerlach 2016/P38 (ICN, DNA 20). COSTA RICA. Province of Alajuela: Alajuela Co. Cordillera Central, Poasito, $10^{\circ} 9^{\prime} 25^{\prime \prime} \mathrm{N}$, $84^{\circ} 11^{\prime} 46^{\prime \prime} \mathrm{W}$, alt. $1917 \mathrm{~m}$, sur le tronc d'un décidu, dans le jardin du restaurant, 22 Jan. 2013, P. Clerc \& C. Rojas 2015/247 (G).

Usnea subpectinata Stirt., Scott. Naturalist (Perth) 6: 108. 1881.

(Fig. 13A-H)

\section{MycoBank MB 408525}

Type: Scotland, New Galloway, 1880, McAndrew s.n., specimen D (BM! - lectotype). Chemistry: usnic, constictic, norstictic, stictic, salazinic (trace), menegazziaic and protocetraric acids. $\% \mathrm{C} / \mathrm{M} / \mathrm{A}: 5 / 29 / 31, \mathrm{~A} / \mathrm{M}=1.1, \mathrm{~A} / \mathrm{C}=6, \mathrm{M} / \mathrm{C}=5.6$.

Description $(\mathrm{n}=44)$. Thallus shrubby to subpendulous when optimally developed, 4-12(-19) cm long; soft with \pm anisotomic-dichotomous ramifications (main branches); basal part brownish-black or pale reddish on the first $\mathrm{mm}$ and then concolorous with branches; main branches 1-2 mm diameter, slightly to strongly irregular, remaining nearly the same diameter over their whole length, to slowly tapering in longitudinal section, irregularly and inconspicuously segmented; branch segments usually not swollen, terete to \pm flattened in transversal section, with sparse annular cracks; lateral branches slightly constricted (main branches) to distinctly constricted; terminal branches with few ramifications; foveolae, transverse furrows sometimes present but never numerous; maculae and pseudocyphellae absent; papillae and tubercles absent (not to be mistaken with early stages of fibril growth); fibrils numerous and densely arranged (at on the end of some branches), thin and slender to \pm spinulose up to $3 \mathrm{~mm}$ (Fig. 13G), but the majority around $1 \mathrm{~mm}$ (Fig. 13H); fibercles present, scattered, conspicuous on main branches; soralia (Fig. 13A-E): a) punctiform, 70-120 (-170) $\mu \mathrm{m}$ large, b) circular to irregular when crowded (top view), c) plane to slightly stipitate (side view), d) typically convex-efflorescent, e) thin cortical rim, f) 6-9 soralia $/ 0.25 \mathrm{~mm}^{2}, \mathrm{~g}$ ) mostly remaining individual, sometimes aggregating, rarely fusing together in large convex-efflorescent consoralia covering the apices, h) mostly on terminal branches; isidiomorphs usually numerous, often growing in fasciculate clusters (Fig. 13D); isidiofibrils numerous, easily breakable, often covering the surface of branches; apothecia sometimes present, subterminal; ascospores 7.5-10 × 5-6.5 $\mu \mathrm{m}$ $(\mathrm{n}=10)$; pycnidia not seen; cortex thin (Table 1), shiny, of the ceratina-type; medulla thick (Table 1), dense to compact, two-layered; axis thin (Table 1). CMA of the cornuta-type (Figs 4, 13H).

Chemistry. Stictic, \pm constictic, \pm crypstostictic, \pm menegazziaic, \pm norstictic and \pm salazinic acids, \pm unidentified possible triterpenoids with Rf Class A/B/C: 5/2-3/? $(\mathrm{n}=26)$; medulla $\mathrm{K}+$ pale yellow, $\mathrm{P}+$ pale yellow to yellow orange. Soralia: $\mathrm{K}-, \mathrm{P}-$ or $\mathrm{P}+$ pale yellow orangish (Fig. 3).

Distribution and habitat. Because $U$. subpectinata was confused with U. cornuta s.str., it is difficult to have a precise idea of its distribution. In Europe where it seems to be much rarer than $U$. cornuta s.str., it is known so far from Scotland (type locality) and France (Brittany and South 
Corsica). This suggests an Atlantic Mediterranean type of distribution. In South America, U. subpectinata was found so far in Brazil, where it seems to be widespread, corticolous or lignicolous, in rural areas, pastures, lower montane moist forests and Araucaria forests of the Mata Atlantica between 900 and $1400 \mathrm{~m}$ elevation. In Costa Rica, this species was found corticolous or lignicolous, on isolated trees (e.g., Alnus accuminata) in rural areas, pastures, roadsides, between 1000 and $2000 \mathrm{~m}$ elevation, or in mountain tropical forests (on Quercus spp.) between 1500 and $2500 \mathrm{~m}$ elevation. Usnea subpectinata was further found in El Salvador on Pinus carribea (Cupressus lusitanica forest) and on Pinus sp. in pine-oak forests between 1700 and $1800 \mathrm{~m}$ elevation.

Diagnostic notes. Usnea subpectinata in its typical form is characterized by the subpendulous growth form with conspicuous main branches, numerous small fibrils (Fig. 13F) and slender isidiofibrils (Fig. 13E) present on main branches, either regularly arranged or irregularly in patches, convex-efflorescent punctiform to enlarging soralia (Fig. 13D), cornuta-type of CMA (Fig. 13H) and the presence of stictic acid in the medulla which reacts $\mathrm{K}+$ yellow and $\mathrm{P}+$ yellow orangish.

Variation. The soralia may vary from punctiform and even with the cortex to \pm stipitate, convex-efflorescent and larger than half the branch diameter (Fig. 13A-E). Branches may be covered with isidiomorphs, isidiofibrils and small fibrils or be almost completely depauperate, for instance in young and necrotic thalli. Sometimes the segments of the main branches might be more swollen and the lateral branches more distinctly constricted, as it is usually the case in this species. The medulla may vary from compact to almost loose (Fig. 13H).

Discussion. Usnea subpectinata corresponds to lineage 9 in Gerlach et al. (2019) and Figure 1.

It forms a strong supported lineage including samples mainly from Brazil, one from Costa Rica and one from
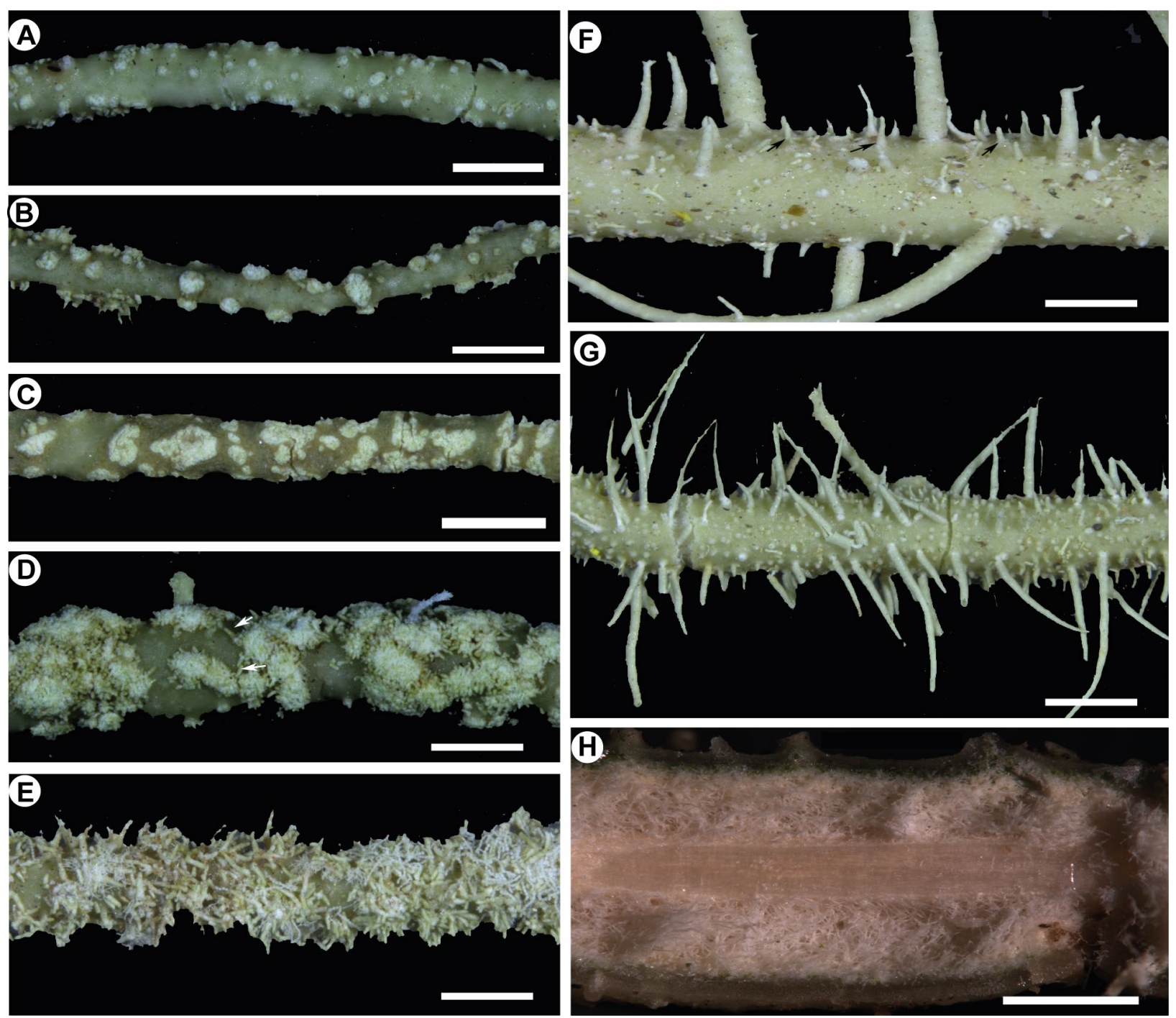

Figure 13. Usnea subpectinata. A - young, isolated, \pm stipitate soralia (Clerc, Gerlach \& Feuerstein 17/54, DNA 300); B - isolated, stipitate, enlarging soralia (Gerlach, Clerc \& Dal-Forno 2414, DNA 420); C - consoralia without isidiomorphs (Gerlach, Clerc \& Dal-Forno 2410, DNA 384); D - consoralia with isidiomorphs (Gerlach, Clerc \& Feuerstein 2299, DNA 359); E - consoralia covered with isidiomorphs and isidiofibrils (Gerlach \& Penati 2016/P59, DNA 29); F - short, \pm spinulose fibrils (Gerlach, Clerc \& Dal-Forno 2394, DNA 396); G - short and longer slender fibrils \pm densely arranged on branch (Gerlach 2016/P20, DNA 116); H - transversal section of main branch, CMA of cornuta-type with dense medulla (Gerlach \& Penati 2016/P69). Scales: A-H $=500 \mu \mathrm{m}$. 
France (Fig. 1). Since the type of Usnea subpectinata collected in 1880 is too old, it was not possible to extract DNA. This is a difficult situation, since there is a stictic acid chemotype of $U$. cornuta s.str. occurring in Europe. It is quite easy to separate morphologically both taxa when specimens are optimally developed. Unfortunately, the original material of $U$. subpectinata is small and looks depauperate. However, we decided to assign the specimen of lineage 9 to $U$. subpectinata based on the following arguments: 1. Lineage 9 was found to occur as well in Europe (France, South Corsica); 2. Some soralia of the original material of $U$. subpectinata are larger than $1 / 2$ diameter of the branch and they do not seem to be consoralia; 3 . There are some short fibrils and isidiofibrils on the branches of the same original material, however, not in large quantities. This is perhaps because the material is old and the fragile isidiomorphs and isidiofibrils fell off over the years; 4 . In the protologue Stirton (1881) wrote that the specimens of the new taxon 'give the impression of Hypnum tamariscinum'. This moss with its typical erect 2-3 pinnate frondose stems might indeed recall a well developed specimen of $U$. subpectinata with its numerous \pm spinulose fibrils.

We are aware that this is a tricky decision, but since on the other hand we could not find arguments against it based on the morphology, the anatomy and the chemistry of the original material of $U$. subpectinata, we preferred to use this name rather than describing a new taxon. Collecting of further European material of lineage 9, especially in Scotland, is now required to validate this decision and choose an appropriate epitype or invalidate it and describe a new species. We searched for specimens from Scotland and stictic acid from Scotland in G herbarium, but unfortunately found none.

Among the species of the Usnea cornuta s.l. aggr., $U$. subpectinata stands out by its constant chemistry with the stictic acid aggr. Only the stictic acid chemotype of $U$. cornuta s.str. shares the same chemistry. In this case, the subpendulous growth form, the enlarging soralia and the presence of isidiofibrils arranged regularly or in scattered patches are diagnostic for U. subpectinata. The presence of numerous isidiofibrils looking like spinulose fibrils in $U$. subpectinata might potentially lead to confusion with $U$. dasaea. However, the latter species lacks the numerous and delicate isidiofibrils that are characteristic of the former species and has a different medullary chemistry with galbinic, norstictic and salazinic acids. Usnea perhispidella is a similar species with the stictic acid group. The latter taxon differs from $U$. subpectinata mainly by lacking constricted lateral, by a much thinner medulla (13-20\%), a much thicker central axis (44-56\%) and consequently with a higher ratio $\mathrm{A} / \mathrm{M}(>2)$ (Truong et al. 2013b). Molecular analysis showed clearly that these two superficially similar species are unrelated phylogenetically (Gerlach et al. 2019).

Selected specimens analyzed. BRAZIL. Minas Gerais, Gonçalves, on fences, 08 Juin 2016, A. Gerlach \& R. Penati 2016/P24 (ICN, DNA 160). Rio Grande do Sul: São Francisco de Paula, Flona de São Francisco de Paula, 2014, A. Gerlach et al. 1523 (ICN). Santa Catarina: Alfredo Wagner, Reserva

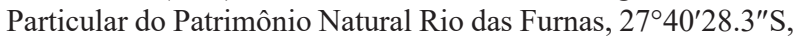
$49^{\circ} 10^{\prime} 37.9^{\prime \prime} \mathrm{W}$, alt. $870 \mathrm{~m}$, on A. angustifolia, 09 Jan. 2014, A. Gerlach \& C. Alves 1246 (ICN). COSTA RICA. Province of San Jose: Pérez Zeledón, Co. Cordillera de Talamanca, San Gerardo de Rivas, $9^{\circ} 28^{\prime} 13.5^{\prime \prime} \mathrm{N}, 83^{\circ} 35^{\prime} 7.0^{\prime \prime} \mathrm{W}$, alt. $1486 \mathrm{~m}$, sur Alnus accuminata, 2014, P. Clerc 2015/638 (G, DNA 227). EL SALVADOR. Department of Santa Ana: Metapán, Parque Nacional Montecristo, tronc et branches de Pinus sp. Pine-Oak forest, $14^{\circ} 23^{\prime} 33.99^{\prime \prime} \mathrm{N}, 89^{\circ} 22^{\prime} 41.93^{\prime \prime} \mathrm{W}$, alt. $1700 \mathrm{~m}$, 17 Jan. 2013, P. Clerc, C. Rojas \& E. Morales 2015/1175 (G). FRANCE. Bretagne: Finistère, Carrefour de la Chapelle, Juin 1984, P. Clerc s.n. (G).

\section{Usnea trachyclada (Müll. Arg.) Zahlbr.}

(Fig. 14A-G)

MycoBank MB 408537

Basionym: Usnea barbata var. trachyclada Müll. Arg., Hedwigia 30: 224. 1891.

Type: [Brazil], Minas Gerais, Serra do Ouro Branco, on Vellosia, 1887, Schenck 4487 (G! - holotype). Denkschr. Kaiserl. Akad. Wiss. Wien, Math.-Naturwiss. K1. 83: 183. 1909. Chemistry: usnic, thamnolic, squamatic and barbatic (trace) acids (by Clerc in 1996). \% $\mathrm{C} / \mathrm{M} / \mathrm{A}: 4.5 / 37.5 / 16 . \mathrm{A} / \mathrm{M}=3.6$. $\mathrm{M} / \mathrm{C}=8.3$.

Epitype: [Brazil], Santa Catarina, Alfredo Wagner, Reserva Particular do Patrimônio Natural Rio das Furnas, $27^{\circ} 40^{\prime} 28.3^{\prime \prime} \mathrm{S}$, 49¹0'37.9"W, $\sim 870$ m, Mai 2016, A. Gerlach 2016/P46 (G! epitype, designated here; MycoBank MBT 392846; GenBank: MF669820). Chemistry: usnic and thamnolic acids. \%C/M/A: $5 / 35 / 21 ; \mathrm{A} / \mathrm{M}=0.6, \mathrm{M} / \mathrm{C}=7$.

Description $(\mathrm{n}=30)$. Thallus shrubby, soft to \pm rigid, up to $7 \mathrm{~cm}$ long, with anisotomic-dichotomous ramifications; basal part thinner and usually paler than main branches, with sometimes some irregular blackish areas at the very base; main branches $1-1.8 \mathrm{~mm}$ diameter, slightly to distinctly irregular longitudinally, distinctly segmented with medulla mainly visible at ramification points; segments cylindrical to slightly swollen, \pm terete to slightly and \pm irregularly flattened in transversal section; lateral branches slightly to distinctly constricted, rarely not constricted at attachment points; terminal branches \pm thick with few anisotomic ramifications; foveolae and transverse furrow present but generally rare, rarely numerous; maculae absent; pseudocyphellae absent; papillae (early stages of fibrils?) small and verrucous, usually scattered on main branches, rarely numerous, densely covering the branches; tubercles absent; fibrils few to numerous, scattered, slender of various length $(\leq 2 \mathrm{~mm})$, rapidly shed; fibercles slender, scattered and irregularly disposed; soralia (Fig. 14): a) punctiform, generally $\leq 1 / 2$ branch diameter, up to $300 \mu \mathrm{m}$, rarely enlarging (Fig. 14E), b) \pm circular in top view, c) usually distinctly stipitate, but sometime only slightly stipitate on young thalli, d) usually plane, rarely convex and efflorescent, e) thin cortical rim (Fig. 14C), always visible, f) $3-5(-7)$ soralia $/ 0.25 \mathrm{~mm}^{2}$, g) remain usually isolated, rarely aggregating and covering the terminal branches (Fig. 14G), h) most of the time on terminal branches, rarely on main branches; isidiomorphs usually short, mainly on young soralia, absent from mature soralia except when soralia are large and convex-efflorescent; 

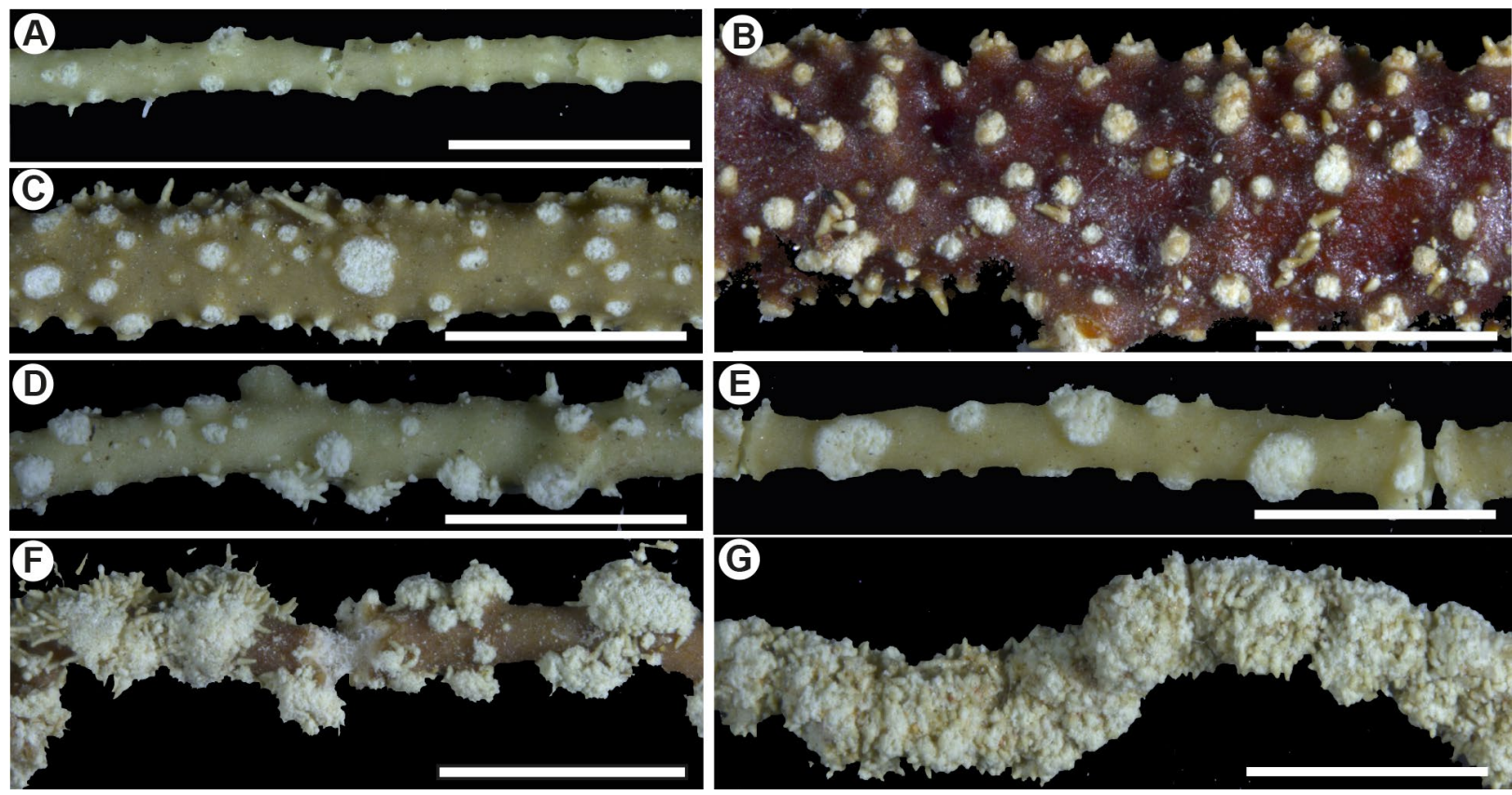

Figure 14. Usnea trachyclada. A - young, punctiform soralia on terminal branches (Gerlach 2016/P3); B - small stipitate soralia (Schenck 4487, holotype); C - soralia with well visible cortical rim (Gerlach \& Beilke 1134); D - mature, distinctly stipitate, individual soralia (Clerc 2015/798); $\mathrm{E}$ - rare, large soralia, \pm circular in top view (Clerc 2015/163); F - convex efflorescent soralia with a tendency to aggregate (Fleig 6172b); $\mathrm{G}$ - overmature aggregating soralia covering terminal branches (Fleig 6172b). Scales: $\mathrm{A}-\mathrm{G}=500 \mu \mathrm{m}$.

isidiofibrils usually absent or rare, rarely numerous on main branches; apothecia rare and immature; cortex thin to moderately thin (Table 1), shiny, of the ceratina-type; medulla thick (Table 1), lax to dense, heterogeneous; axis thin (Table 1). CMA of the cornuta-type (Fig. 4).

Chemistry $(\mathrm{n}=13)$. Thamnolic acid, \pm squamatic acid, \pm unknown grey Rf Class A/B/C: 1/1/1 (US35-sugar); medulla $\mathrm{K}+$ bright yellow $\rightarrow$ orangish. Soralia: $\mathrm{K}+$ bright yellow, P+ deep yellow (Fig. 3).

Distribution and habitat. So far found only in Brazil and in Costa Rica. Corticolous on twigs or lignicolous on fences in rural areas, lower montane moist forests, Araucaria forests and Campo de altitude in the Mata Atlantica between 900 and $2000 \mathrm{~m}$ elevation in Brazil. In Costa Rica, this species was found corticolous or lignicolous, on isolated trees (e.g., Alnus accuminata, Cupressus sp.) in rural areas, pastures, roadsides, between 1500 and 2000 m elevation.

Diagnostic notes. Usnea trachyclada is characterized by the sparse, punctiform to rarely large, rarely aggregating, \pm circular in top view, distinctly stipitate soralia (Fig. 14D) and by the presence of thamnolic acid as main medullary. Thamnolic acid seems to be concentrated in the soralia and $U$. trachyclada is the only species of the $U$. cornuta aggr. in Brazil whose soralia react $\mathrm{K}+$ bright yellow.

Variation. Typical soralia are distinctly stipitate (Fig. 14B, D), but they might be sometimes almost even with the cortex (Fig. 14A) or on the contrary convex-efflorescent (Fig. 14F) looking like the soralia of $U$. arianae. Another striking variation is the presence of foveoles/ transverse furrows and the degree of ridges development that is extreme on the type material, almost absent on the recently collected material.

Discussion. Usnea trachyclada corresponds to lineage 3 in Gerlach et al. (2019) and Figure 1.

The original material of Usnea trachyclada consists of four specimens, all of them with strongly ridged and acute-angled main branches in cross section with foveoles and transverse furrows. None of the specimens of lineage 3 or other Brazilian specimens with thamnolic acid shows such extreme characteristics, but a few foveoles. However, all these specimens of the original collection have a very thin cortex and a large medulla. Clerc (1998) showed that these characteristics are frequently associated with structures such as foveoles and transverse furrows. We thus consider the original material as an extreme morphotype of $U$. trachyclada and decided to assign lineage 3 to this species.

Usnea trachyclada differs from all species of the $U$. cornuta aggr. described in this article, by the $\mathrm{K}+$ bright yellow reaction of the soralia due to the presence of thamnolic acid and its well supported position in the phylogenetic tree (Fig. 1).

Several other species are known to produce thamnolic acid in the medulla: Usnea koyana (TNS-holotype!) is a Japanese species characterized by a very small (up to $5 \mathrm{~cm}$ ) thallus mostly consisting of only one main branch with small lateral branches not or only slightly constricted at ramification points with stipitate soralia as well. The cortex of $U$. koyana is thicker (9-14\%) (Ohmura 2001) and has thin and longitudinal cracks not deep enough to reach the medulla; Usnea yakushimensis (TNS-holotype!) is a subpendulous, pendulous species with a characteristic basal part, concolorous with main branches and with annular-cracks, lateral branches that are not constricted at ramification points and punctiform soralia that are not 
stipitate and never enlarge. This taxon is very close to U. hondoensis; Usnea subfloridana has a distinct jet-black pigmented basal part, lateral branches that are not constricted at ramification points, soralia that are not stipitate, a much larger and mat cortex and a CMA that is not of the tenuicorticata/cornuta-type; Usnea cornea (W-holotype!) is a rather large South African species (up to $15 \mathrm{~cm}$ long) with numerous transverse furrows, lateral branches that are not or slightly constricted at ramification points, numerous small and irregularly shaped (top view) punctiform soralia growing on low tubercle-like structures; Usnea fragilescens is a widespread species corticolous or saxicolous (Europe, North America, Asia, Canary island) similar to U. cornuta (see Clerc \& Otte 2018 for differences). This species is mentioned with several chemotypes (Ohmura 2001) and recently a new chemotype with thamnolic acid was reported for La Gomera, Canary Island (van den Boom et al. 2015). A specimen with thamnolic acid collected by S. Clayden in Newfoundland corresponds well to this species. Further studies are needed to see whether the various chemotypes of this species (salazinic or stictic or thamnolic/squamatic or psoromic acids) deserve species rank; Usnea subscabrosa containing typically protocetraric acid has a much rarer thamnolic acid chemotype. However, the cortex of this species is much thicker and the lateral branches are not constricted. The specimen with thamnolic acid by Saag et al. (2011) and identified as U. cornuta clustered together with U. subscabrosa (data not shown) in our analysis.

Selected specimens analyzed. BRAZIL. Paraná, Guaratuba, Morro dos Perdidos, campos de altitude, on fences, 03 Juin 2013, A. Gerlach, E. Gumboski \& S. Eliasaro 1036 (G). Santa Catarina: Alfredo Wagner, Reserva Particular do Patrimônio Natural Rio das Furnas, $27^{\circ} 40^{\prime} 28.3^{\prime \prime} \mathrm{S}, 49^{\circ} 10^{\prime} 37.9^{\prime \prime} \mathrm{W}$, alt. $900 \mathrm{~m}$, em galhos caidos, 2016, A. Gerlach et al. 2016/P3 (ICN). São Paulo: Serra de Paranapiacaba, 60 km südwestlich von São Paulo, oberhalb von Juqitiba, in einem hellen, feuchten Urwald am Rio Juquiá, alt. 800 m, 1978, K. Kalb \& P. Plobst s.n. (G). COSTA RICA. Province of Puntarenas: Coto Brus Co., Las Tablas, $8^{\circ} 56^{\prime} 47.2^{\prime \prime} \mathrm{N}, 83^{\circ} 44^{\prime} 24.8^{\prime \prime} \mathrm{W}$, alt. 1771 m, 2013, P. Clerc \& C. Rojas 2015/153 (G).

\section{Key to the shrubby-subpendulous sorediate species of the Usnea cornuta aggr. in Brazil}

For reasons explained at the beginning of this taxonomic treatment, species identification with the help of a dichotomous key in the $U$. cornuta aggregate, is extremely difficult and requires a lot of experience. TLC examination is here absolutely required, especially in the $U$. cornuta aggr. or when the $\mathrm{K}$ and $\mathrm{P}$ reactions are negative. In some cases (immature thalli, extreme or with lichenicolous fungi parasitized morphotypes) and when TLC is not diagnostic, DNA barcoding can help for a correct identification. One should be careful when looking at soralia, not to confound large soralia with consoralia.

1 Medulla $\mathrm{K}+$ yellow to orange-red or $\mathrm{K}-, \mathrm{P}-($ Usnea cornuta s.1.)...................... 2 Medulla $\mathrm{K}-, \mathrm{P}+$ (protocetraric acid) (Usnea brasiliensis s.1.).....................

2(1) Soralia $\mathrm{K}+$ bright yellow (thamnolic acid) ......... $\ldots \ldots \ldots \ldots \ldots \ldots \ldots \ldots \ldots$. trachyclada Soralia $\mathrm{K}-($ thamnolic acid absent $) \ldots \ldots \ldots \ldots 3$
3(2) Medulla lax, with conspicuous interspaces between the hyphae, hyphal strands often in packets; soralia large, well delimited of circular outline even with the cortex or encircling the branch, \pm concave, or \pm conspicuously convex; barbatic acid \pm stictic acid aggr. . . . . . . . . ....................... macaronesica

Medulla dense to compact, without conspicuous interspaces between the hyphae, hyphal \pm homogeneously disposed; soralia punctiform, but often aggregating in consoralia; barbatic acid absent . ............4

4(3) Medulla $\mathrm{K}-$, P- (caperatic acid) ...... U. boomiana Medulla $\mathrm{K}+$ or $\mathrm{K}-, \mathrm{P}-$ (caperatic acid absent) . . . . . 5

5(4) Fatty acid (Rf: 4/5/5 and 4-5/6/5-6), \pm norstictic acid or lobaric acid ................... arianae Not this chemistry $\ldots \ldots \ldots \ldots \ldots \ldots \ldots$

6(5) Salazinic and constictic acids or constictic acid alone . . 7 Stictic acid present .................. 8

7(6) Soralia stipitate, \pm enlarging, consoralia absent or rare ........................ stipitata

Soralia not stipitate, soralia punctiform, aggregating in consoralia ............... U. cornuta s.str.

8(6) Isidiofibrils and small spinulose fibrils densely and locally present on main branches.........U. subpectinata Isidiofibrils and small spinulose fibrils not densely present on main branches. ................... specimens belonging to lineage 14

9(1) Cortical/subcortical orange-reddish pigment present (sometimes only close to the basal part) ..........

U. rubropallens

Cortical/subcortical orange reddish pigment absent 10

10(9) Soralia large, $>1 / 2$ branch diameter, lapponica-type, barbatic acid present or absent . . . . . . . . . . 11 Soralia small, $<1 / 2$ branch diameter, not lapponica-type, barbatic absent ................... 12

11(10) Barbatic \pm stictic or \pm protocetraric acids . . . . . . . .................... macaronesica Barbatic acid absent, only protocetraric acid. .

U. tenuicorticata

$12(10) \mathrm{M} / \mathrm{C}<7 \ldots \ldots \ldots \ldots \ldots \ldots$. brasiliensis s.str.

$\mathrm{M} / \mathrm{C}>7 \ldots \ldots \ldots \ldots \ldots \ldots \ldots \ldots$

13(12) Branches fan-shaped, soralia aggregating or fusing into consoralia . . . . . . flabelliformis Branches not fan-shaped, soralia well-delimited not fusing into consoralia . . . . . . tenuicorticata

\section{Acknowledgments}

The first author acknowledges CNPq (Brazil) for the financial support for field-trips (2015-2016); as well the grant received from Swiss Government Excellence Scholarship (2016-2017) that supported her yearlong stay in Switzerland. We thank the Societé de physique et d'histoire naturelle de Genève by the Bourse Augustin Lombard that supported field trips in Brazil during December 2017 and molecular labwork in the CJB during first trimester 2018.

The first author would also like to thank all her colleagues who helped during the fieldwork especially Manuela Dal-Forno, Fabiane Lucheta, Shirley Feuerstein, and Rodrigo Penati. Andre 
Aptroot kindly provides fresh specimens of $U$. arianae and $U$. cornuta from Tenerife. We also acknowledge the Directors of the collection sites in Brazil for granting collecting permits (Ministério do Meio ambiente collecting permit nr. 41595-5) and the curators of the cited herbaria (BM, TNS, W) who kindly sent specimens on loan, especially Mara Rejane Ritter, Camila Carneiro and Márcia Pinheiro (ICN herbaria). Specimens from Porto Santo Island were collected under collecting permit 1/ PNM/2016. We thank Ana Palma de Figueira and Samuel Jordan for their help in the laboratory. We thank Carlos Boluda for fruitful discussions. Field work in Costa Rica and El Salvador was partially supported by projects 731-B2-224 and 731-B4107 from University of Costa Rica. Appreciation is extended to ACLAP for granting permission to work in Costa Rica and to Ricardo Morales and the Montecristo National Park for permission to work in El Salvador. We thank the reviewers of the manuscript, as well as the associate editors for providing helpful comments and corrections.

\section{Supplementary electronic material}

File S1. Localities and chemistry of all specimens analyzed in this study. Download file

File S2. Specimens of Usnea used in the study including voucher information, chemotype and GenBank accession numbers. Download file

File S3. Individual ITS gene tree from STACEY analysis showing the phylogenetic placements of all Usnea cornuta lineages analyzed in this study. Download file

File S4. Individual MCM7 gene tree from STACEY analysis showing the phylogenetic placements of all Usnea cornuta lineages analyzed in this study. Download file

File S5. Individual $R P B 1$ gene tree from STACEY analysis showing the phylogenetic placements of all Usnea cornuta lineages analyzed in this study. Download file

File S6. Species tree from STACEY analysis. This phylogenetic tree corresponds to the same showing in Figure 1. Download file

\section{References}

Amo de paz, G., Cubas, P., Divakar, P. K., Lumbsch, H. T. \& Crespo, A. 2011. Origin and Diversification of Major Clades in Parmelioid Lichens (Parmeliaceae, Ascomycota) during the Paleogene Inferred by Bayesian Analysis. PLoS One 6(12): e28161.

Andermann, T., Fernandes, A. M., Olsson, U., Töpel, M., Pfeil, B., Oxelman, B., Aleixo, A., Faircloth, B. C. \& Antonelli, A. 2019. Allele phasing greatly improves the phylogenetic utility of ultraconserved elements. Systematic Biology 68: 32-46.

Bailey, R. \& James, P. 1979. Birds and the dispersal of lichen propagules. The Lichenologist 11: 105-106.

Bouckaert, R., Heled, J., Kühnert, D., Vaughan, T., Wu, C.-H., Dong, X., Suchard, M. A., Rambaut, A. \& Drummond, A. J. 2014. BEAST 2: a software platform for Bayesian evolutionary analysis. Plos Computational Biology 10(4): e1003537.

Brodo, I. M., Sharnoff, D. \& Sharnoff, S. 2001. Lichens of North America. Yale University Press, New Haven \& London.

Bungartz, F., Truong, C., Herrera-Campos, M. \& Clerc, P. 2018. The genus Usnea (Parmeliaceae, Lecanoromycetes) in the Galapagos Islands. Herzogia 31: 571-629.

Caviró, E. A. 2015. Sistemática integrada del género Usnea Dill. Ex Adans. (Parmeliaceae) en la Península Ibérica. PhD dissertation. Madrid, Spain.

Clerc, P. 1984. Contribution à la révision de la systématique des usnées (Ascomycotina, Usnea) d'Europe I. Usnea florida (L.) Wigg. emend. Clerc. Cryptogamie, Bryologie et Lichenologie 5: 333-360.
Clerc, P. 1987a. On the morphology of soralia in the genus Usnea. Bibliotheca Lichenologica 25: 99-102.

Clerc, P. 1987b. Systematics of the Usnea fragilescens aggregate and its distribution in Scandinavia. Nordic Journal of Botany 7: 479-495.

Clerc, P. 1998. Species concepts in the genus Usnea (lichenized Ascomycetes). The Lichenologist 30: 321-340.

Clerc, P. 2004. Notes on the genus Usnea Adanson. II. Bibliotheca Lichenologica 88: 79-90.

Clerc, P. 2006. Synopsis of Usnea (lichenized Ascomycetes) from the Azores with additional information on the species in Macaronesia. The Lichenologist 38: 191-212.

Clerc, P. 2007. Usnea. In: Nash, T. H., Gries, III, C. \& Bungartz, F. (eds), Lichen Flora of the Greater Sonoran Desert Region Vol. 3, pp. 302-335. Tempe: Lichen Unlimited, Arizona State University, Arizona.

Clerc, P. 2011. Usnea. In: Thell, A. \& Moberg, R. (eds), Nordic Lichen Flora Vol. 4, pp. 107-127. Uddevalla: Nordic Lichen Society.

Clerc, P. 2016. Notes on the genus Usnea (lichenized Ascomycota, Parmeliaceae). IV. Herzogia 29: 403-411.

Clerc, P. \& Herrera-Campos, M. A. 1997. Saxicolous species of Usnea subgenus Usnea (lichenized Ascomycetes) in North America. The Bryologist 100: 281-301.

Clerc, P. \& Otte, V. 2018. Usnea viktoriana (Ascomycota, Parmeliaceae), a new European taxon of the Usnea barbata-dasopoga group, with a key to the shrubby-subpendulous sorediate Usnea species in Europe. The Lichenologist 50: 513-527.

Clerc, P. \& Kissling, A. 2019. Les Baillets (Russin, Genève, Suisse) : un «hotspot» pour le genre Usnea Adans. (Parmeliaceae, Ascomycètes lichénisés) en Europe. Saussurea 48: 125-137.

Culberson, C. F. \& Ammann, K. 1979. Standardmethode zur Dünnschichtchromatographie von Flechtensubstanzen. Herzogia 5: 1-24.

Culberson, C. F. \& Johnson, A. 1982. Substitution of methyl tert-butyl ether for diethyl ether in the standardized thin-layer chromatographic method for lichen products. Journal of Chromatography 238: 483-487.

Dal Forno, M., Bungartz, F., Yánez-Ayabaca, A., Lücking, R. \& Lawrey, J. D. 2017. High levels of endemism among Galapagos basidiolichens. Fungal Diversity 85: 45-73.

Degelius, G. 1935. Das ozeanische Element der Strauch- und Laubflechtenflora von Skandinavien. Acta Phytogeographica Suecica 7: $1-411$.

Fernández-Mendoza, F,Domaschke, S., García, M. A., Jordan, P, Martín, M. P. \& Printzen, C. 2011. Population structure of mycobionts and photobionts of the widespread lichen Cetraria aculeata. Molecular Ecology 20: 1208-1232.

Galloway, D. J. \& Aptroot, A. 1995. Bipolar lichens: a review. Cryptogamic Botany 5: 184-191.

Geml, J., Kauff, F., Brochmann, C. \& Taylor, D. L. 2010. Surviving climate changes: high genetic diversity and transoceanic gene flow in two arctic-alpine lichens, Flavocetraria cucullata and F. nivalis (Parmeliaceae, Ascomycota). Journal of Biogeography. 37: 1529-1542.

Gerlach, A., Clerc, P. \& Borges da Silveira, R. M. 2017. Taxonomy of the corticolous, shrubby, esorediated, Neotropical species of Usnea Adans. (Parmeliaceae) with an emphasis on Southern Brazil. The Lichenologist 49: 199-238.

Gerlach, A., Toprak, Z., Naciri, Y., Caviró, E. A., Borges da Silveira, R. M. \& Clerc, P. 2019. New insights into the Usnea cornuta aggregate (Parmeliaceae, lichenized Ascomycota): Molecular analysis reveals high genetic diversity correlated with chemistry. Molecular Phylogenetics and Evolution 131: 125-137. [Available online 30 October 2018]

Hale, M. E. Jr. 1979, How to Know the Lichens, 2nd edition. Dubuque, Iowa: William C. Brown. 
Halonen, P., Clerc, P., Goward, T., Brodo, I. M. \& Wulff, K. 1998. Synopsis of the genus Usnea (lichenized Ascomycetes) in British Columbia, Canada. The Bryologist 101: 36-60.

Herrera-Campos, M. A., Clerc, P. \& Nash, T. H. III. 1998. Pendulous species of Usnea from the temperate forests in Mexico. The Bryologist 101: 303-329.

Herrera-Campos, M. A., Nash, T. H. III \& Garcia, A. Z. 2001. Preliminary study of the Usnea fragilescens aggregate in Mexico. The Bryologist 104: 235-259.

Jones, G., Aydin, Z., Oxelman, B. 2015. DISSECT: an assignment-free Bayesian discovery method for species delimitation under the multispecies coalescent. Bioinformatics 31: 991-998.

Jones, G. 2016. STACEY: species delimitation and phylogeny estimation under the multispecies coalescent. https://doi.org/10.1101/010199

Lücking, R., Dal Forno, M., Moncada, B., Coca, L. F., Vargas-Mendoza, L. Y. et al. (50 more authors). 2017a. Turbo-taxonomy to assemble a megadiverse lichen genus: seventy new species of Cora (Basidiomycota: Agaricales: Hygrophoraceae), honouring David Leslie Hawksworth's seventieth birthday. Fungal Diversity 84: 139-207.

Lücking, R., Moncada B., McCune, B., Farkas, E., Goffinet, B., Parker, D., Chaves, J. L., Lökös, L., Nelson, P. R., Spribille, T., Stenroos, S., Wheeler, T., Yanez-Ayabaca, A., Dillman, K., Gockman, O. T., Goward, T., Hollinger, J., Tripp, E. A., Villella, J., Álvaro-Alba, W. R., Arango, C. J., Cáceres, M. E. S., Coca, L. F., Printzen, C., Rodríguez, C., Scharnagl, K., Rozzi, R., Soto-Medina, E. \& Yakovchenko, L. S. 2017b. Pseudocyphellaria crocata (Ascomycota: Lobariaceae) in the Americas is revealed to be thirteen species, and none of them is P. crocata. The Bryologist 120 : 441-500.

Lumbsch, H. T. \& Leavitt, S. D. 2011. Goodbye morphology? A paradigm shift in the delimitation of species in lichenized fungi. Fungal Diversity 50: 59-72.

Moncada, B., Lücking, R. \& Suárez, A. 2014. Molecular phylogeny of the genus Sticta (lichenized Ascomycota: Lobariaceae) in Colombia. Fungal Diversity 64: 205-231.

Muñoz, J., Felicísimo, A. M., Cabezas, F., Burgaz, A. R. \& Martínez, I., 2004. Wind as a long distance dispersal vehicle in the Southern Hemisphere. Science 304: 1144-1147.

Naciri, Y. \& Linder, H. P. 2015. Species delimitation and relationships: the dance of the seven veils. Taxon 64: 3-16.

Ohmura, Y. 2001. Taxonomic study of the genus Usnea (lichenized Ascomycetes) in Japan and Taiwan. Journal of the Hattori Botanical Laboratory 90: 1-96.

Ohmura, Y. 2012. A synopsis of the lichen genus Usnea (Parmeliaceae, Ascomycota) in Taiwan. Memoirs of the National Museum of Nature and Science 48: 91-137.
Ohmura, Y. \& Clerc, P. 2019. Lectotypification of Usnea confusa (Parmeliaceae, Ascomycota). Bulletin of the National Museum of Nature and Science. Series B, Botany 45: 63-70.

Pérez-Vargas, I, Hernández-Padrón, C., Arroyo \& E. Seriña, R. 2010. Usnea brasiliensis (Zahlbr.) Motyka (Parmeliaceae), a new amphi-Atlantic disjunct lichen species. The Bryologist 113: 308-312.

Rambaut, A., Suchard, M. A., Drummond, W. Xie \& A. J. 2013. Tracer v1.6. http://beast.bio.ed.ac.uk

Rannala, B. \& Yang, Z. 2003. Bayes estimation of species divergence times and ancestral population sizes using DNA sequences from multiple loci. Genetics 164: 1645-1656.

Rizzini, C. T. 1952. Species Organenses generis lichenum Usneae. (Omnes acidum usnicum praebentes). Revista Brasileira de Biologia 12: 337-348.

Rizzini, C. T. 1956. Flora Organensis. Lichenes. Revista Brasileira de Biologia 16: 387-402.

Rodriguez, J. M., Estrabou, C., Truong, C. \& Clerc, P. 2011. The saxicolous species of the genus Usnea subgenus Usnea (Parmeliaceae) in Argentina. The Bryologist 114: 504-525.

RStudio Team. 2015. RStudio: Integrated Development for R. RStudio, Inc., Boston, MA. http://www.rstudio.com

Saag, L., Tõrra, T., Saag, A., Del Prado, R. \& Randlane, T. 2011. Phylogenetic relations of European shrubby taxa of the genus Usnea. The Lichenologist 43: 427-444.

Stirton, J. 1881. On the genus Usnea and a new genus allied to it. Scottish Naturalist 6: 100-107.

Truong, C. 2012. Systematics of the lichen genus Usnea in tropical South America. PhD thesis. University of Geneva, Geneva.

Truong, C., Bungartz, F. \& Clerc, P. 2011. The lichen genus Usnea (Parmeliaceae) in the tropical Andes and the Galapagos: species with a red-orange cortical or subcortical pigmentation. The Bryologist 114: 477-503.

Truong, C., Divakar, P. K., Yahr, R., Crespo, A. \& Clerc, P. 2013a. Testing the use of ITS rDNA and protein-coding genes in the generic and species delimitation of the lichen genus Usnea (Parmeliaceae, Ascomycota). Molecular Phylogenetics and Evolution 68: 357-72.

Truong, C., Rodriguez, J. M. \& Clerc, P. 2013b. Pendulous Usnea species (Parmeliaceae, lichenized Ascomycota) in tropical South America and the Galapagos. The Lichenologist 45: 505-543.

Truong, C. \& Clerc, P. 2016. New species and new records in the genus Usnea (Parmeliaceae, lichenized Ascomycota) from tropical South America. The Lichenologist 48: 71-93.

van den Boom, P. P. G., Clerc, P. \& Ertz, D. 2015. New records of lichens and lichenicolous fungi from La Gomera (Canary Islands, Spain), including the new species: Usnea boomiana P. Clerc. Candollea 70: 165-177. 